Crustal thickness controlled by plate tectonics a review of crust-mantle interaction processes illustrated by European examples

Artemieva, Irina M.; Meissner, Rolf

Published in:

Tectonophysics

DOI:

10.1016/j.tecto.2011.12.037

Publication date:

2012

Document version

Publisher's PDF, also known as Version of record

Citation for published version (APA):

Artemieva, I. M., \& Meissner, R. (2012). Crustal thickness controlled by plate tectonics: a review of crust-mantle interaction processes illustrated by European examples. Tectonophysics, 530-531, 18-49.

https://doi.org/10.1016/j.tecto.2011.12.037 
Review Article

\title{
Crustal thickness controlled by plate tectonics: A review of crust-mantle interaction processes illustrated by European examples
}

\author{
Irina M. Artemieva ${ }^{\mathrm{a}, *}$, Rolf Meissner ${ }^{\mathrm{b}}$ \\ a University of Copenhagen, Denmark \\ ${ }^{\mathrm{b}}$ Kiel University, Germany
}

\section{A $R$ T T I C L E I N F}

\section{Article history:}

Received 16 February 2011

Received in revised form 22 December 2011

Accepted 29 December 2011

Available online 8 January 2012

\section{Keywords:}

Seismic reflectivity

Delamination

Extension

Magmatism

Variscides

Eclogitization

\begin{abstract}
A B S T R A C T
The continental crust on Earth cannot be extracted directly from the mantle, and the primary crust extracted directly from an early magma ocean is not preserved on Earth. We review geophysical and geochemical aspects of global crust-mantle material exchange processes and examine the processes which, on one side, form and transform the continental crust and, on the other side, chemically modify the mantle residue from which the continental crust has been extracted. Major mechanisms that provide crust-mantle material exchange are oceanic and continental subduction, lithosphere delamination, and mafic magmatism. While both subduction and delamination recycle crustal material into the mantle, mafic magmatism transports mantle material upward and participates in growth of new oceanic and continental crusts and significant structural and chemical modification of the latter. We discuss the role of basalt/gabbro-eclogite phase transition in crustal evolution and the links between lithosphere recycling, mafic magmatism, and crustal underplating. We advocate that plate tectonics processes, together with basalt/gabbro-eclogite transition, limit crustal thickness worldwide by providing effective mechanisms of crustal (lithosphere) recycling.

The processes of crust-mantle interaction have created very dissimilar crustal styles in Europe, as seen by its seismic structure, crustal thickness, and average seismic velocities in the basement. Our special focus is on processes responsible for the formation of the thin crust of central and western Europe, which was largely formed during the Variscan (430-280 Ma) orogeny but has the present structure of an "extended" crust, similar to that of the Basin and Range province in western USA. Major geophysical characteristics of the Variscan lithosphere are discussed within the frame of possible sequences of crust-mantle material exchange mechanisms during and after main orogenic events in the European Variscides.
\end{abstract}

(c) 2012 Elsevier B.V. All rights reserved.

\section{Contents}

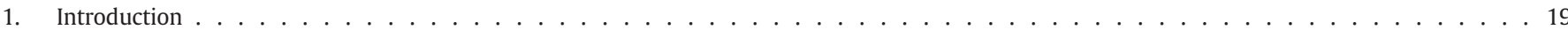

1.1. Primary crusts and planetary-scale differentiation . . . . . . . . . . . . . . . . . . . . . . . . . . . . . . . . . . . 19

1.2. Primary crusts and plate tectonics on terrestrial planets . . . . . . . . . . . . . . . . . . . . . . . . . . . . . . 20

1.2.1. Earth . . . . . . . . . . . . . . . . . . . . . . . . . . . . . . . . 20

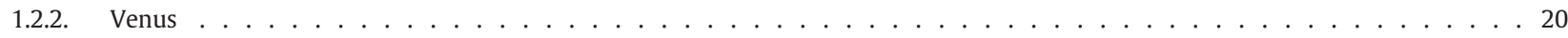

1.2.3. Mars . . . . . . . . . . . . . . . . . . . ............... 21

1.2.4. Moon and Mercury . . . . . . . . . . . . . . . . . . . . . . . . . . . . . . . . . . . . . . 21

1.3. Geodynamic controls of crustal volume . . . . . . . . . . . . . . . . . . . . . . . . . . . . . . . . . . . . . . . . . . . . 21

2. Crust-mantle exchange processes: a global view . . . . . . . . . . . . . . . . . . . . . . . . . . . . . . . . 22

2.1. Crust-mantle compositional balance: a planetary-scale geochemical perspective . . . . . . . . . . . . . . . . . . . . . . . . . 22

2.2. Making new continental crust . . . . . . . . . . . . . . . . . . . . . . . . . . . . . . . . . . . . 23

2.2.1. Growth of continental crust: convergent margins versus intraplate settings . . . . . . . . . . . . . . . . . . . . . . . 23

2.2.2. Growth rate of the continental crust . . . . . . . . . . . . . . . . . . . . . . . . . . . . . . . . . . 24

2.3. Mafic magmatism: volcanism and intrusions. . . . . . . . . . . . . . . . . . . . . . . . . . . . . . . . . . 24

2.3.1. Geodynamic causes of mafic volcanism . . . . . . . . . . . . . . . . . . . . . . . . . . . . . . . . . . 24

2.3.2. The shape of magmatic intrusions . . . . . . . . . . . . . . . . . . . . . . . . . . . . . . . . . . . . . . 24

\footnotetext{
* Corresponding author. Tel.: + 45 50882438; fax: + 4535322501

E-mail address: irina@geo.ku.dk (I.M. Artemieva).
} 


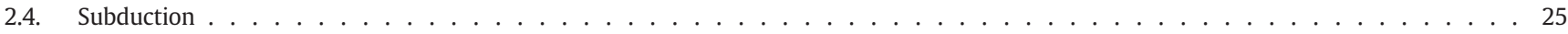

2.4.1. Precambrian subduction. . . . . . . . . . . . . . . . . . . . . . . . . . . . . . 25

2.4.2. Modern oceanic subduction . . . . . . . . . . . . . . . . . . . . . . . . . . . . . 27

2.4.3. Continental collision and subduction . . . . . . . . . . . . . . . . . . . . . . . . . . . . . . . . . . . . . . . . . . . . . . 27

2.4.4. Recycling rate at subduction zones . . . . . . . . . . . . . . . . . . . . . . . . . . . 27

2.5. Thermo-mechanical recycling of the lithosphere. . . . . . . . . . . . . . . . . . . . . . . . . . . . . . . . 28

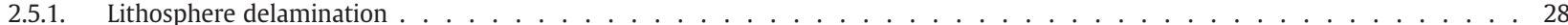

2.5.2. Delamination of the lower crust: geochemical evidence . . . . . . . . . . . . . . . . . . . . . . . . . . . . . . . 29

2.5.3. Delamination of the lower crust: geophysical perspective . . . . . . . . . . . . . . . . . . . . 29

2.5.4. Thermal and thermo-mechanical erosion . . . . . . . . . . . . . . . . . . . . . . . . . . . . . . . . . 30

3. Peculiarities of crustal velocity structure in central and Western Europe . . . . . . . . . . . . . . . . . . . . . . . . . . . . 30

3.1. Making Paleozoic Europe. . . . . . . . . . . . . . . . . . . . . . . . . . . . . . . . . . . . . . 30

3.2. Crustal thickness in Europe. . . . . . . . . . . . . . . . . . . . . . . . . . . . . . . . . . . . . . . 30

3.2.1. Crustal roots in young collisional orogens. . . . . . . . . . . . . . . . . . . . . . . . . . . . . . . . . . . 30

3.2.2. Cratonic crustal roots . . . . . . . . . . . . . . . . . . . . . . . . . . . . . . . . . . . . . . . . . . . . . . . . . .

3.2.3. Crustal roots in Paleozoic orogens: Uralides. . . . . . . . . . . . . . . . . . . . . . . . . . . . 32

3.2.4. Missing crustal roots in Caledonides and Variscides . . . . . . . . . . . . . . . . . . . . . . . . . . . . . . 34

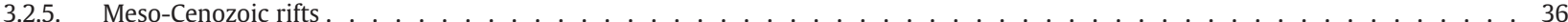

3.3. Seismic evidence for lower crustal delamination in the Variscides. . . . . . . . . . . . . . . . . . . . . . . . . . . . . . . . . . . . 36

3.3.1. Mean crustal velocity in western Europe . . . . . . . . . . . . . . . . . . . . . . . . . . . . . . . . . . 36

3.3.2. Thickness of crustal layers . . . . . . . . . . . . . . . . . . . . . . . . . . . . . . . . . . . 37

3.4. Structure of the Variscan lithospheric mantle . . . . . . . . . . . . . . . . . . . . . . . . . . . . . . . . 37

3.4.1. Delaminated lithosphere ... . . . . . . . . . . . . . . . . . . . . . . . . . . . . . . 37

3.4.2. Is the Variscan lithospheric mantle partly preserved? . . . . . . . . . . . . . . . . . . . . . . . . . . . . 37

4. Seismic reflections in the lithosphere of Western Europe . . . . . . . . . . . . . . . . . . . . . . . . . . . . 38

4.1. Reflections from the lower crust . . . . . . . . . . . . . . . . . . . . . . . . . . . . . . . . . . . . . . . . . . . . . . . . 38

4.1.1. Observations . . . . . . . . . . . . . . . . . . . . . . . . . . . . . 38

4.1.2. Interpretations . . . . . . . . . . . . . . . . . . . . . . . . . . . . . . . . 39

4.2. Reflections in the upper mantle . . . . . . . . . . . . . . . . . . . . . . . . . . . . . . . . . . . . . . . . 40

5. How was the Variscan crust created? . . . . . . . . . . . . . . . . . . . . . . . . . . . . . . . . . . . . . . . . . . . . . 40

5.1. Major characteristics of the present-day Variscan lithosphere. . . . . . . . . . . . . . . . . . . . . . . . . . 40

5.2. Why is the mafic lower crust missing? . . . . . . . . . . . . . . . . . . . . . . . . . . . . . . . . . . . . . . 42

5.3. Unanswered questions. . . . . . . . . . . . . . . . . . . . . . . . . . . . . . . . . . . . . . . . . 42

6. Conclusions . . . . . . . . . . . . . . . . . . . . . . . . . . . . . . . . . . . . . . . . 43

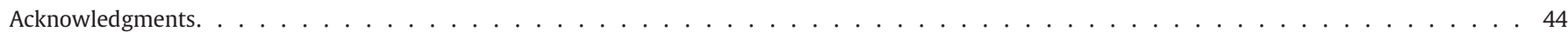

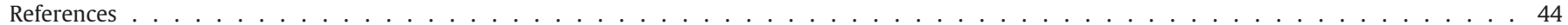

\section{Introduction}

\subsection{Primary crusts and planetary-scale differentiation}

In contrast to undifferentiated bodies like most asteroids, all terrestrial planets have a differentiated internal structure (e.g. Nimmo and McKenzie, 1998; Robinson et al., 2008; Sohl et al., 2005; Solomon, 1980). Planetary-scale differentiation leads to formation of the core and the bulk silicate shell represented by the mantle and the crust. The fundamental differentiation of the terrestrial bodies into core, mantle and crust has taken place already in the first 30-100 Ma after the creation of the solar system around 4.6 Ga (Bourdon et al., 2008; Boyet and Carlson, 2005; Carlson and Lugmair, 1988; Harper et al., 1995; Harrison et al., 2005; Iizuka et al., 2010; Lee and Halliday, 1995; O'Neill and Palme, 1998). On the Earth, the initial internal structure was modified later in the course of intense meteorite bombardment which continued from the moment of the Earth's formation at ca. $4.56 \mathrm{Ga}$ until ca. 4 Ga. The largest collision with a planetary body (the "Giant Impact") that hit the Earth at $\sim 4.53 \mathrm{Ga}$ had a major effect on the compositional structure of the Earth by separating the Moon (Canup, 2004; Kleine et al., 2005; Lucey et al., 2006; Pritchard and Stevenson, 2000) with an anomalously small core volume as compared to the Earth and thus leaving the Earth with a somewhat modified ratio of the core to the bulk silicate shell volumes. Heavy meteorite bombardment erased most of the evidence for the pre-3.9 Ga geological and tectonic evolution of the planet (Ryder, 2003). Although (close to) none of the primary crust remains on the Earth, recent development of experimental geochemistry including high-resolution geochronology provides growing evidence on the existence of the Earth's crust in the Hadean (Dauphas et al., 2007; Harrison et al., 2005; lizuka et al., 2010).

Planetary crusts are formed during and after freezing of a magma ocean, either from low-density material produced by fractional crystallization within the cooling magma ocean (primary crust), or by magmatic additions (volcanic or intrusive) upon or into the preexisting crust which are produced by subsequent partial melting of the mantle (Sharkov and Bogatikov, 2009; Taylor, 1989a). The lunar, the Martian, and the Mercurial crusts are thick: 60 to $120 \mathrm{~km}$ on the Moon, 50 to $100 \mathrm{~km}$ (and perhaps up to $150 \mathrm{~km}$ ) on Mars (with a pronounced crustal dichotomy-a thick, ca. $100 \mathrm{~km}$, crust in the southern hemisphere and a thin, ca. $50 \mathrm{~km}$, crust in the northern hemisphere), and 100 to $200 \mathrm{~km}$ on Mercury (Gudkova and Zharkov, 2004; Neumann et al., 2004; Sohl and Schubert, 2007; Sohl et al., 2005; Solomon, 2003; Solomon et al., 2005; Spohn et al., 2001; Turcotte et al., 2002; Zuber, 2001). It is speculative how much of these crusts are the primary crusts. Crustal thickness on Venus ranges from 20 to $50 \mathrm{~km}$, perhaps even from 0 to $90 \mathrm{~km}$ (Anderson and Smrekar 2006; Nimmo and McKenzie, 1998; Simons et al., 1997), with significant lateral variations as on the Earth, where the crustal thickness has a global average of 20-25 km and ranges from 5.6-7.1 km in "normal" oceans (i.e. oceans where the bathymetry follows the squareroot of ocean-floor age dependence) to $30-50 \mathrm{~km}$ in the continents, regionally thickening to $70-80 \mathrm{~km}$ in the Andes and Tibet (Beck, 2002; Murphy et al., 1997).

It is clear that the ratio of the crustal to the total mantle volume is significantly different on various terrestrial planets: $\sim 1.2 \%$ of on the Earth, $1-4 \%$ on Venus, $5-11 \%$ (or more) on Mars, $~ 11-22 \%$ on the 
Moon, and $10-30 \%$ on Mercury (Fig. $1 \mathrm{~b}$ ). The volume of the primary crust extracted from the magma ocean during planetary-scale differentiation is proportional to the mantle volume, but also depends on mantle composition and $\mathrm{P}-\mathrm{T}$ conditions in the planetary interior. The mantles of the Earth, Mars, Venus, and the Moon are thought to be similar in chemistry and mineralogy (Nimmo and McKenzie, 1998; Sohl and Schubert, 2007; Wieczorek et al., 2006), whereas on Mercury where the ratio of the core relative to the bulk silicate fraction is an unusually high mantle composition can be significantly different (Fig. 1) (Clark, 2007; Rothery et al., 2010; Taylor and Scott, 2004). Given different interior temperatures and sizes of the planets, $\mathrm{P}-\mathrm{T}$ conditions for crustal extraction are very dissimilar on all terrestrial planets, except perhaps on Earth and Venus. We hypothesize that plate tectonics processes, together with basalt-eclogite transition, additionally contribute to a significant difference in the ratio of the crustal to the total mantle volume by limiting crustal thickness on those planets where these mechanisms may operate.

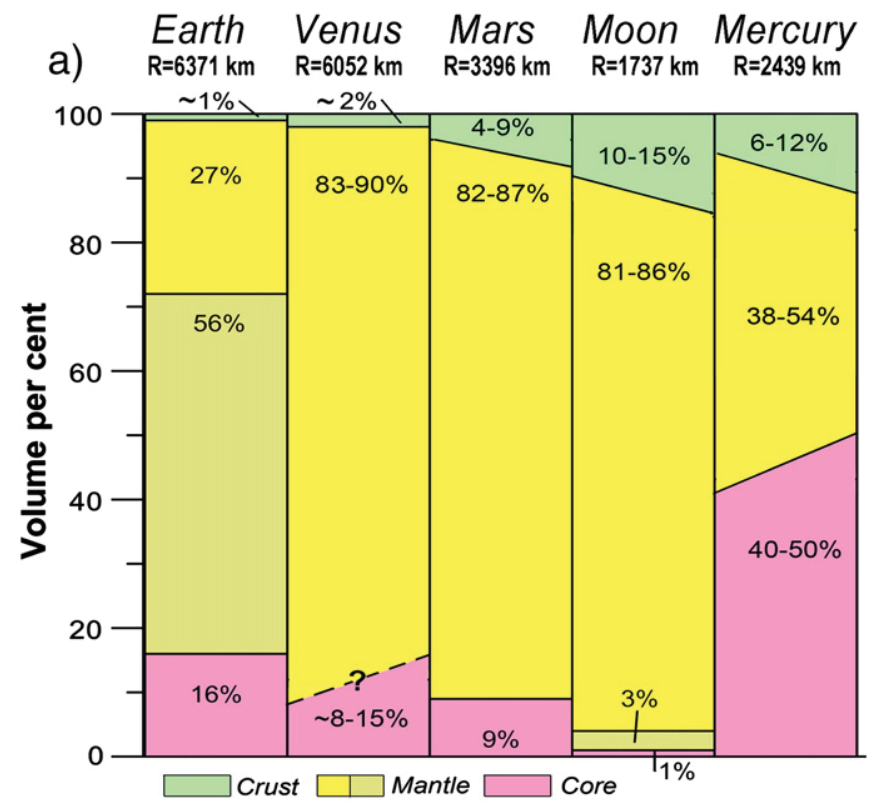

b) Some mechanisms of crustal recycling

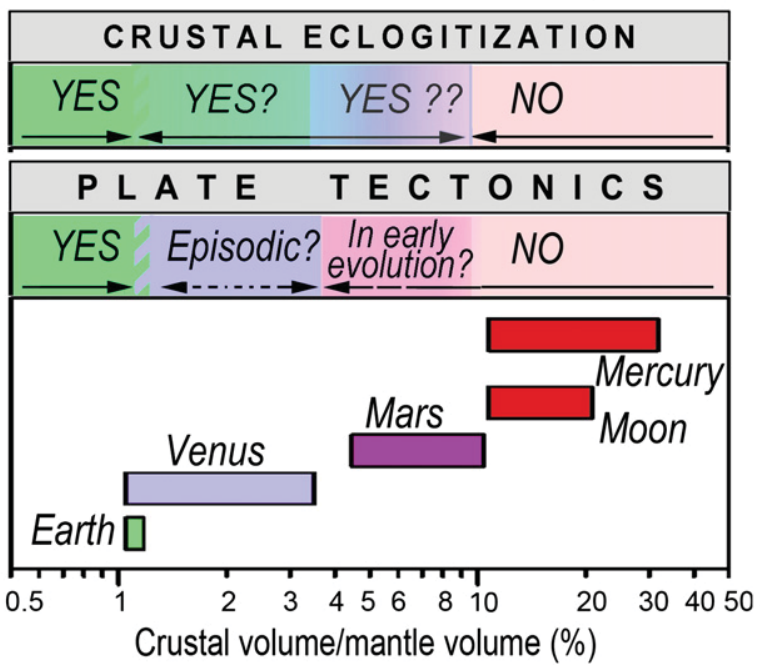

Fig. 1. Sketch of the internal structure of the terrestrial bodies and the relative volume of the crust, mantle and core as percent of the total volume of the bodies (based on data of Gudkova and Zharkov, 2004; Nimmo and McKenzie, 1998; Solomon, 2003; Spohn et al., 2001; Wieczorek et al., 2006; Zuber, 2001). Plate tectonics processes, together with basalt-eclogite transition in the (lower) crust, may have a strong control on the crustal thickness (b).

\subsection{Primary crusts and plate tectonics on terrestrial planets}

\subsubsection{Earth}

Up to date, interpretations of the early plate tectonics on Earth remain highly controversial (see recent summaries by Condie and Pease, 2008; Hatcher et al., 2007). Growing geological, geochemical, tectonic, paleomagnetic, and seismic evidence indicates that some kind of plate tectonics could have operated already on the Archean Earth (Cawood et al., 2006). Some geological studies of the Archean cratons place the start of plate tectonics at ca. $4.0 \mathrm{Ga}$ (De Wit, 1998), whereas the oldest geophysically imaged signature of the plate tectonics processes is ca. $2.7 \mathrm{Ga}$ (Calvert et al., 1995) (see also Section 2.4.1). The present-day interpretations of the geochemical balance of the Earth provide the growing evidence that the crust and the mantle may not be geochemically complementary reservoirs if the Earth's composition is chondritic (e.g. Boyet and Carlson, 2005; Jackson et al., 2010; Salters and Stracke, 2004; although recently argued by Caro and Bourdon, 2010). Periodic switch of plate tectonics could explain the geochemical disparity between the crustal and mantle reservoirs (Carlson, 2011; Davies, 2011). This idea is supported by recent mantle convection models which show that hotter mantle temperatures on the early Earth favor episodicity of Precambrian subduction and plate-driven tectonics (O'Neill et al., 2007b). A periodicity in plate tectonics is caused by the time-dependent changes in elastic lithospheric (the upper thermal boundary layer) thickness and the convective stress, two factors that have opposite effects on subduction initiation: only when the convective stresses exceed the intrinsic strength of the lid, the lid fails and subduction initiates (O'Neill et al., 2007a).

\subsubsection{Venus}

While the Venusian radius and the average crustal thickness are similar to those on Earth, no topographic features resembling terrestrial expressions of plate tectonics are known on Venus at present (Solomon et al., 1992). Anhydrous, predominantly basaltic, composition of the Venusian crust (Surkov et al., 1986) implies its high viscosity and explains major tectonic differences between the Earth and Venus (Mackwell et al., 1998). On Earth weak boundaries separating strong plates play an important role in plate tectonics (Bercovici et al., 2000). In contrast, the present absence of water on Venus results in strong faults (Foster and Nimmo, 1996) and high mantle viscosity (Moresi and Solomatov, 1998; Zhong and Gurnis, 1996) and leads to stagnant lid convection (confined to the deep interior below thick and strong lithosphere). Given that the age of the Venusian surface is only 300-600 Ma (Frankel, 1996; Herrick, 1994), plate tectonics could have existed on Venus prior to the global resurfacing event; the latter could have recycled the primary crust. Although rapid resurfacing on Venus could have been caused either by plate tectonics processes or by plumerelated melt generation, plume activity alone seems to be insufficient to produce global resurfacing, and plate tectonics processes seem to be more plausible (Nimmo and McKenzie, 1998). Numerical models indicate a possibly episodic pattern of plate tectonics with short periods of massive subduction separated by periods of surface quiescence ( $\mathrm{O}$ 'Neill et al., 2007b; Tackley, 2000; Turcotte, 1993).

While the Venusian crust could have been thinned to its present thickness during the resurfacing event with an involvement of plate tectonics processes, other processes (in the absence of the presentday plate tectonics), presently restrict thickness of the Venusian crust to depths similar to global average of the Earth's crust. Given that the Venusian crust is basaltic, its present thickness is thought to be controlled by basalt-eclogite transition (Nimmo and McKenzie, 1998), which occurs at depths of 30-70 km, depending on temperature (Green and Ringwood, 1967; Ito and Kennedy, 1971). However, under dry conditions and in the absence of deformation basalt may remain metastable even to greater depths (Rubie, 1990). 


\subsubsection{Mars}

Alike on Venus, basalt-eclogite transition may also control thickness of the Martian crust, which is proposed to have andesitic-basaltic or basaltic shergottites composition (Sohl et al., 2005). Although satellite observations indicate the absence of the present-day plate tectonics on Mars (Zuber, 2001) and there is no robust evidence that it ever operated there, some authors suggest that plate tectonics could have operated on this planet in the past (Nimmo and Stevenson, 2000; Sleep, 1994; although questioned by van Thienen et al., 2004), depending on whether free liquid water was present on the Martian surface (Catling, 2004; O'Neill et al., 2007a). The existence of plate tectonics on Mars during its early evolution is supported by linear magnetization in the southern hemisphere (Connerney et al., 1999; Lenardic et al., 2004).

\subsubsection{Moon and Mercury}

Both Moon and Mercury are likely to have been stagnant since their formation until present due to the absence of surface water (Lewis, 1988; Lissauer, 1997). Basalt-eclogite phase transformation also seems to be unimportant in limiting thicknesses of the non-basaltic lunar and Mercurial crusts which are made chiefly of primordial anorthosites (e.g. Ashwal, 2010; Greenhagen et al., 2010; Jeanloz et al., 1995). As noted earlier, both Moon and Mercury have a very high ratio of crustal to mantle volume, which may be a consequence of the absence of both plate tectonics and crustal delamination advanced by eclogitization.

The observation that the terrestrial bodies with (i) continuous or episodic plate tectonics and (ii) basaltic (lower) crust which may undergo eclogitization have a very low ratio of crustal to mantle volume (Fig. 1b) advocates a strong role of plate tectonics processes which, together with basalt-eclogite transition, limit crustal thickness by providing effective mechanisms of crustal (lithosphere) recycling into the mantle. The next sections discuss some evidence in support of this hypothesis by reviewing the crust-mantle material exchange processes that operate on Earth.

\subsection{Geodynamic controls of crustal volume}

We now focus our discussion on the crustal structure on Earth, the characteristic features of which are: (1) a (nearly) complete absence of the primary crust extracted from the early magma ocean and (2) the presence of the continental crust which cannot be extracted directly from the mantle. Crustal thickness (and thus the total volume of the planetary crust) is controlled by a dynamic interplay of crust-mantle material exchange processes (crustal growth and crustal recycling), and not all of them require plate tectonics. Major geodynamic processes responsible for growth and recycling of the Earth's crust include (Fig. 2): mafic magmatism, crustal (lithospheric) delamination, oceanic subduction, and continental subduction. By continental subduction we mean subduction associated with collisional orogens although, strictly speaking, in most cases slabs correspond to pre-collisional subduction of oceanic lithosphere that has been consumed from the surface.

(i) Crustal growth. Plume-related magmatic additions (volcanic or intrusive) to the crust and crustal (or lithosphere) delamination may exist both on the Earth and on terrestrial bodies with stagnant-lid convection regime. In the presence of plate tectonics, additional mechanisms of crustal volume growth through mafic magmatism are those related to the presence of midocean ridges and subduction zones: (a) decompressional melting of passively ascending mantle material at mid-ocean ridges responsible for formation of new oceanic crust (Fig. 3a) and (b) magmatic processes at subduction zones responsible for formation of new continental crust (Fig. 3b). Scenarios for generation of the continental crust are highly debated, given that granitic magmas cannot be extracted directly from the upper mantle and their petrogenesis remains controversial (Kemp and Hawkesworth, 2003; Petford et al., 2000). Intraplate plumerelated magmatism (which does not require plate tectonics regime) with associated magmatic underplating contributes not only to the crustal growth but also to chemical and structural modification of the continental crust. Major tectonic settings where magmatism and the associated crustal growth can take place are summarized in Fig. 4a.

(ii) Crustal recycling. Crustal growth is limited by two plate tectonic processes, namely oceanic and continental subductions, as well as by crustal (lithospheric) delamination (the latter may also be caused by density changes due to phase transitions, e.g. eclogitization, and thus may operate in the absence of plate tectonics). These processes recycle lithospheric material back into the mantle and thus control the crustal volume. In the "feed-back loop", the recycled crustal material, being chemically and mineralogically different from the mantle, stimulates mantle melting and magmatism, in particular at convergent settings, but also at intraplate settings during lithospheric extension. Extensional processes themselves can be initiated and supported by passive mantle upwellings generated by thermo-chemical convection or by reorganization of lithospheric plates.

Diversity of tectonic settings within the European continent allows to find regional illustrations to all major geodynamic processes responsible for crustal growth and its recycling into the mantle. Phanerozoic evolution of the crust, the main topic of our research in central and western Europe, was governed and controlled by modern plate tectonic processes which operated together with mantle dynamics. In western Europe they included Phanerozoic orogenic events related to the collision of Baltica, Laurentia, and Avalonia, the closure of the Iapetus Ocean and the Tornquist Sea, and subsequent amalgamation of a series of terranes at the edge of the East European craton. We start with a general overview of the geochemical perspective on crust-mantle links (Section 2); it provides grounds for better understanding of the tectonic

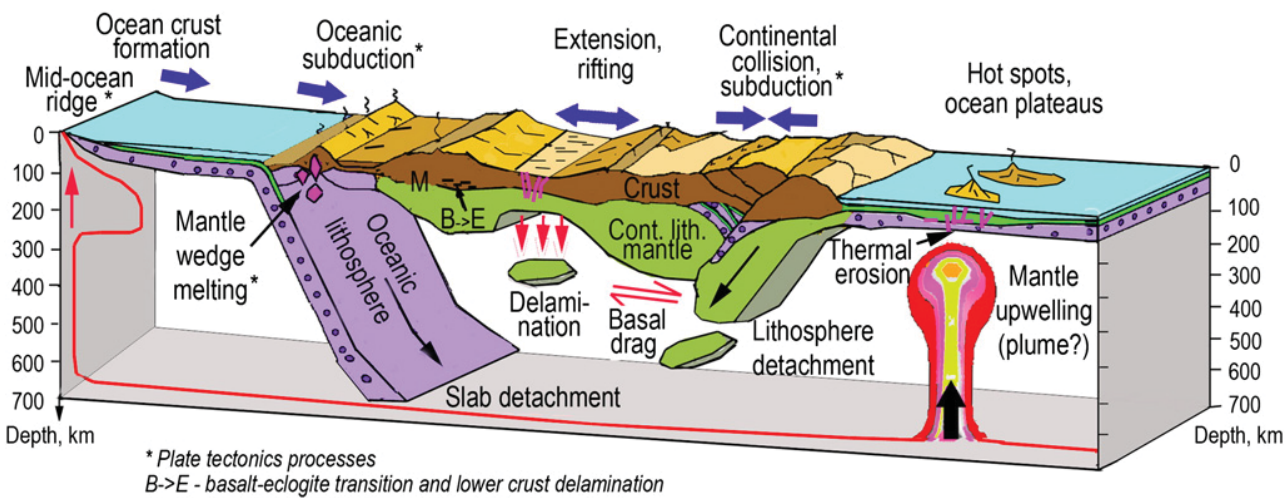

Fig. 2. Sketch of major processes controlling crust-mantle material exchange. Vertical and horizontal dimensions are not to scale. 
a)

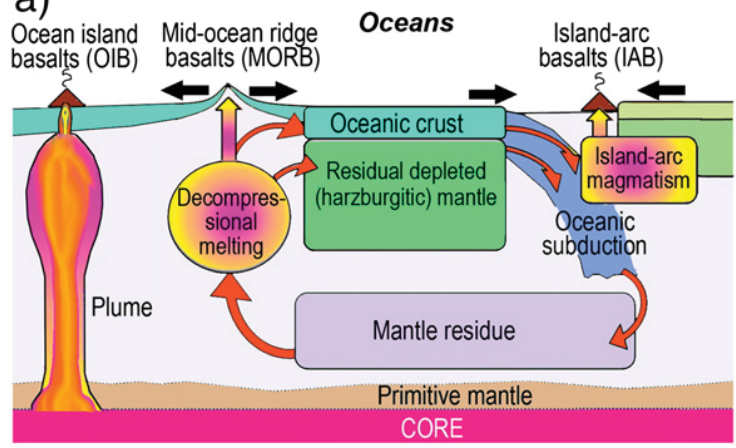

b)

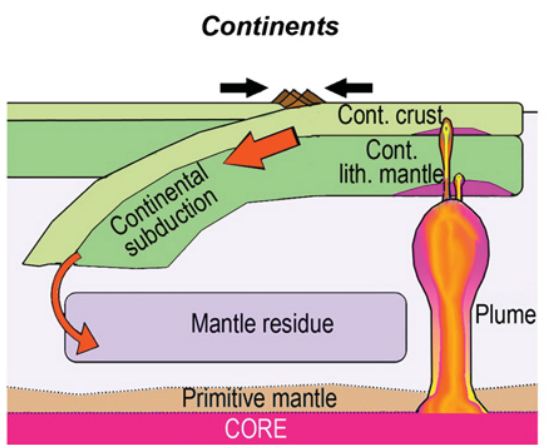

Fig. 3. Sketch illustrating geochemical relations between mantle, oceanic crust and continental crust. Melting of the depleted convecting upper mantle generates midocean ridge basalts and produces oceanic crust. A significant amount of the oceanic crust together with the associated residual depleted mantle is recycled back in subduction zones refertilizing the mantle and producing island-arc magmatism which plays an important role in formation of the continental crust. The enriched upper mantle is the source of ocean-island basalts. Large-scale mantle upwellings (plumes) as well as small-scale convective instabilities (not shown) transport mantle material into the continental lithosphere and lead to crustal growth, particularly notable in LIPs. Vertical and horizontal dimensions are not to scale.

and geodynamic processes that are imaged by seismic methods. We next summarize geophysical (mostly seismic) evidence for crustmantle material exchange processes using continental Europe as an example (Section 3). Our special focus is on the Variscan crust which, despite its Paleozoic age, has crustal structure typical for present-day extensional settings. We discuss the peculiarities of the structure of the Variscan crust, its past and modern tectonic analogues, and tectonic processes which may have created the modern lithospheric structure of the Phanerozoic Europe (Section 4).

\section{Crust-mantle exchange processes: a global view}

2.1. Crust-mantle compositional balance: a planetary-scale geochemical perspective

Planetary-scale differentiation resulted in the formation of two fundamentally different portions of the Earth: the iron-rich core that was formed at $33 \pm 2$ My after the beginning of the Solar System (Kleine et al., 2002) and the outer silicate portion of the Earth (the mantle plus the crust) that was termed by Hart and Zindler (1986) as the Bulk Silicate Earth (BSE). The BSE consists of several geochemical reservoirs (McDonough and Sun, 1995; O'Neill and Palme, 1998; Taylor and McLennan, 1995):

- the primitive (undifferentiated) mantle that, by definition, has composition of BSE;

- the depleted convecting upper mantle (with a mass fraction of $\sim 0.50 \pm 0.15$ of BSE) that is the source of mid-ocean ridge basalts (MORB);

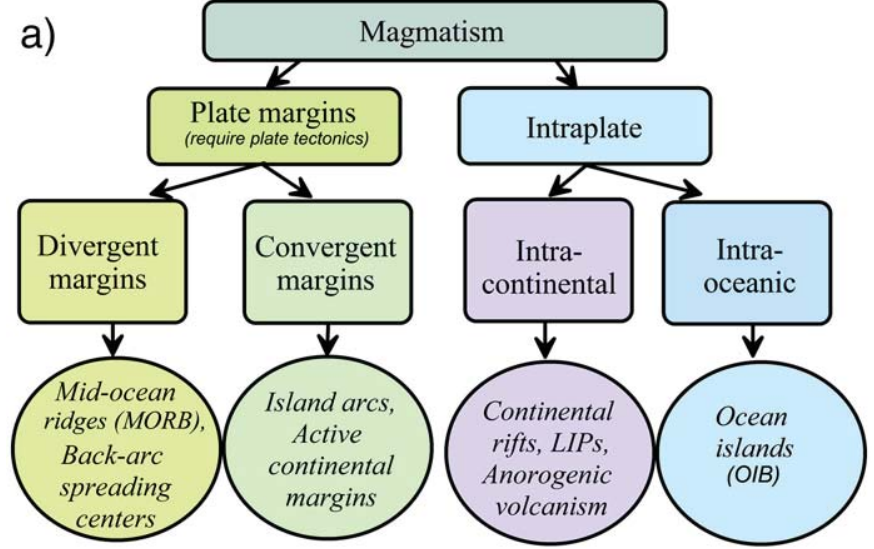

b)

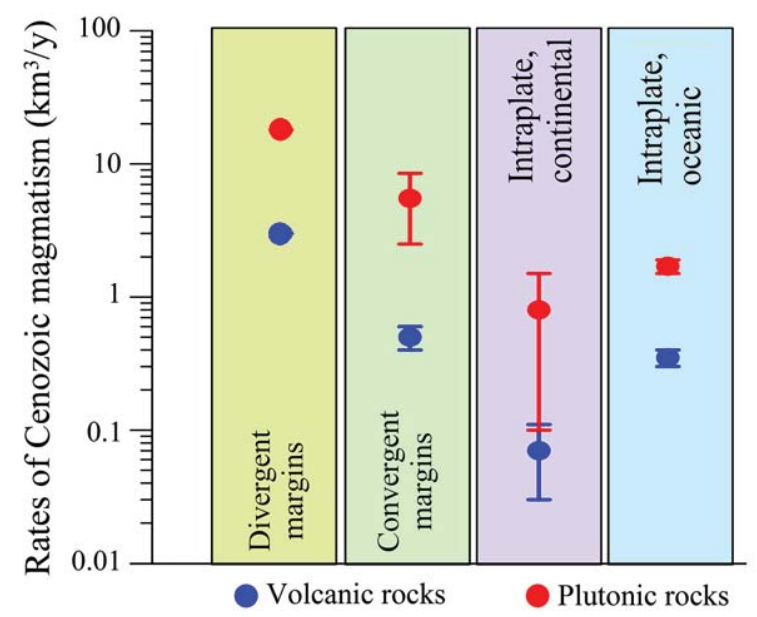

Fig. 4. Major types of magmatism. (a) Diagram showing major types of magmatism associated with specific tectonic settings. (b) Global rates of Cenozoic magmatism in various tectonic settings (based on data of Wilson, 1995). Later studies indicate greater role of crustal production at convergent margins. See text for discussion.

- the enriched upper mantle that is the source of ocean-island basalts (OIB);

- the oceanic crust;

- the suboceanic lithospheric mantle;

- the continental crust (with the mass fraction of 0.0054 of BSE);

- the subcontinental lithospheric mantle (with a mass fraction of no more than 0.04 of BSE);

- hydrosphere and atmosphere.

Decompression-induced partial melting of depleted mantle is the process thought to be responsible for generation of mid-ocean ridge basalts (MORB) and thus of the oceanic crust (Fig. 3a). Modern production rate of MORB is estimated to be $20 \mathrm{~km}^{3} /$ year (Hoffman, 1989) (Fig. 4b). The products of melt segregation, namely the oceanic crust formed by the melt material and the residual depleted mantle, are chemically complementary (O'Neill and Palme, 1998). Oceanic crust with an average thickness of $\sim 7 \mathrm{~km}$ can be produced by adiabatic upwelling of the mantle with a potential temperature of $\sim 1300{ }^{\circ} \mathrm{C}$, while higher potential temperature $\left(1450-1500^{\circ} \mathrm{C}\right)$ generates enough basaltic melt to produce oceanic crust up to $25 \mathrm{~km}$ thick (e.g. McKenzie and Bickle, 1988). Cooling of the oceanic plate, when it moves away from the mid-ocean ridge, produces oceanic lithosphere which has the same composition as the surrounding mantle. A significant amount of the oceanic crust and the associated residual depleted mantle is recycled back into the depleted mantle in subduction zones. However, islandarc magmatism that plays an important role in formation of the continental crust, brings back some of the most highly incompatible trace elements to the near-surface settings (Fig. 3a). 
In contrast to the oceanic crust, the continental crust cannot be directly differentiated from the mantle, and most geochemical models propose a two-stage process with the initial extraction of basaltic magmas from the mantle and their subsequent remelting or fractional crystallization (Rudnick, 1995, 2003; Taylor and McLennan, 1985). Trace-element abundances in the average continental crust and normal mid-ocean ridge basalts (N-MORB) are complementary: enrichments of the continental crust in incompatible elements are mirrored by depletions in the same elements in N-MORB (Taylor and McLennan, 1985). This observation led to the key concept in mantle geochemistry: the upper mantle is depleted (as compared to the primitive mantle) primarily due to extraction of the continental crust. Geochemical data indicate the depleted mantle should fill not only the upper mantle, but also a significant portion of the lower mantle (McCulloch and Bennett, 1998). However, the composition of the continental crust, that has $\sim 60 \%$ of $\mathrm{SiO}_{2}$, is unlikely to be in the equilibrium with the mantle composition (e.g. Hawkesworth and Kemp, 2006a). In particular, granitic (in a broad sense) rocks play an important role in crustal evolution (Douce, 1999). Their petrogenesis remains controversial leading to different, highly debated, scenarios for the continental crust generation.

\subsection{Making new continental crust}

\subsubsection{Growth of continental crust: convergent margins versus intraplate} settings

Since granitic magmas cannot be extracted directly from the upper mantle, three geochemical processes by which the granitic crust can be formed include (Kemp and Hawkesworth, 2003): “(i) fractional crystallization of primary basaltic liquid, (ii) mixing between partial melts of pre-existing crust and mantle-derived magmas, or their differentiates, and (iii) partial melting of young, mantle-derived mafic protoliths in the crust" (i.e. remelting within the crust). Geodynamic processes (mutually non-exclusive) by which the continental crust can be produced include:

- subduction-related processes at convergent margins (island-arcs settings) (Fig. 3a) and

- plume-related magmatism with fractional crystallization of primary basaltic liquid (Fig. 3b).

At compressive tectonic settings, growth of the continental crust occurs by additions of new continental crust (produced by magmatic underplating and mixing between partial melts of pre-existing crust and mantle-derived magmas) and also by accretion of oceanic plateaus, submarine turbidite fans, and fragments of juvenile oceanic crust. In intraplate settings, plume-related magmatism with associated magmatic underplating contributes to the crustal growth, if granitic magmas contain a component of juvenile mantle-derived material. Since the lowermost crust typically does not reach temperatures high enough $\left(800-900{ }^{\circ} \mathrm{C}\right.$ ) for partial melting (Artemieva and Mooney, 2001) (Fig. 5), generation of a significant volume of granitic magmas on time scales of up to 100 My requires heat advection to the crustal base, for example by underplating or interplating by mafic magmas (Clemens, 2006) (see Section 2.3).

Primitive island-arc basalts (IAB) and ocean-island basalts (OIB) represent two end-member compositions of basaltic magmas that make new material added to the continental crust. The former constrain compositions of basaltic magmas typical for subduction settings, while the latter-composition of the present-day intra-plate magmas (e.g. Sun and McDonough, 1989). Despite IAB and OIB represent two endmember basaltic compositions that participate in the formation of new continental crust, average major element composition of the latter does not correspond to a simple mixture between IAB and OIB. Instead it is represented by average composition of the lower crust that can be modeled by a mixture of $\sim 92 \%$ of IAB and $\sim 8 \%$ of OIB. It implies that throughout the Earth's history the continental crust is primarily

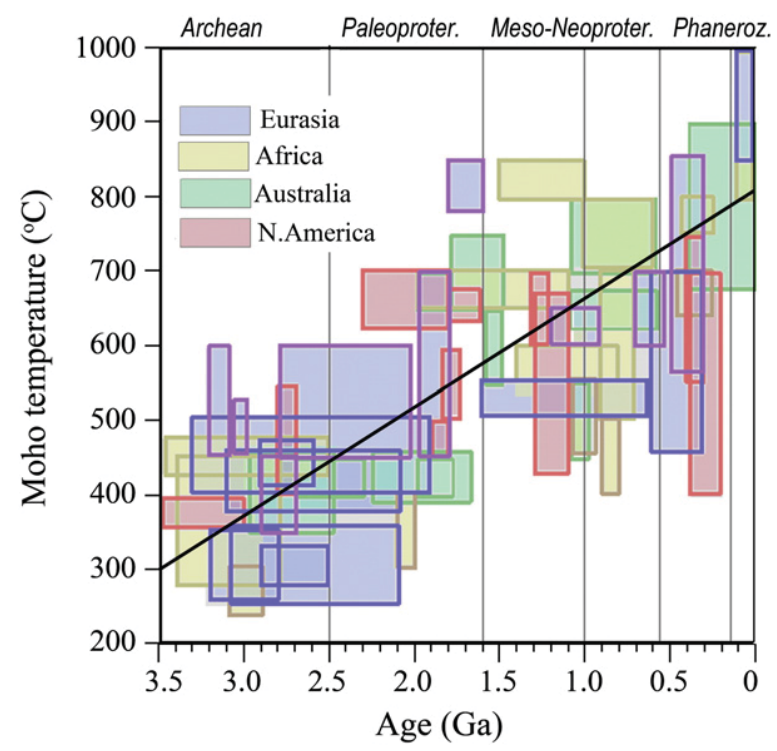

Fig. 5. Typical temperatures at the base of the continental crust versus tectono-thermal age (based on data of Artemieva and Mooney, 2001). Boxes correspond to different tectonic structures. The plot accounts for significant regional variations in crustal thickness.

generated at convergent margins (island-arcs settings) (Barth et al., 2000; Rudnick, 1995).

Nevertheless, plume-related magmatism could have been a principal mechanism for generation of a new crust in the Archean (Fig. 6), when plate tectonics was only beginning to operate (the debate about the start of plate tectonics is presented by Condie and Pease, 2008 and is outside the scope of the present review). In particular, the existence of convergent margins with the associated subduction zones in the Archean is not indisputably proven; an exception may be a 2.69 Ga subduction imaged by seismic reflection in the Canadian Shield (Calvert et al., 1995). Plume-related magmatism provides a convenient explanation for the origin of tonalite-trondheimite-granodiorite (TTG)

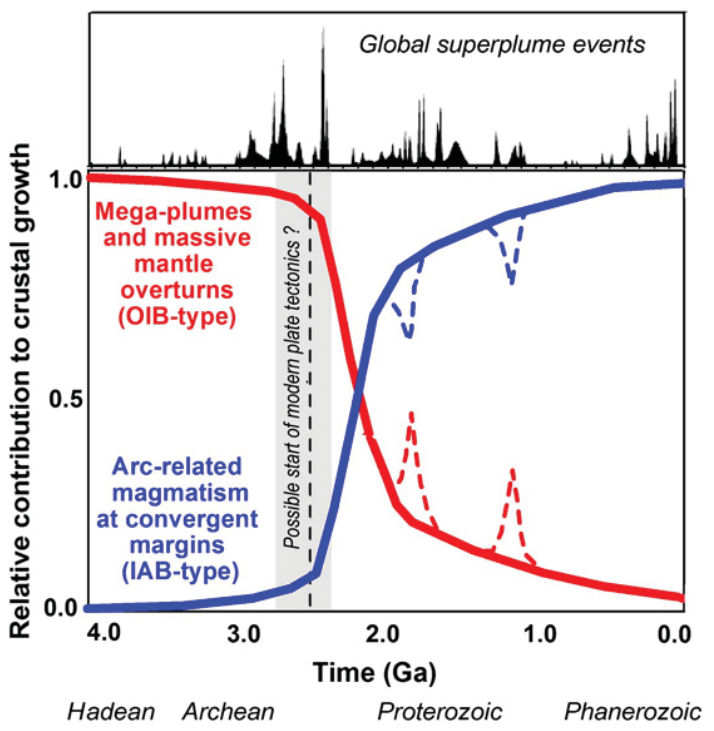

Fig. 6. Sketch showing relative contributions of magmatism caused by mega-plumes and mantle overturns (red) and arc-related magmatism at convergent settings (blue) to generation of the crust. While plume-related magmatism may have been important on the early Earth, the role of arc-related magmatism became dominant with the start of plate tectonics. The upper plot shows distribution of superplume events (from Condie, 2004). If peaks in crustal growth at ca. $1.9 \mathrm{Ga}$ and $1.1 \mathrm{Ga}$ were caused by mega-plume events (red dashed lines), the relative contribution of subduction-related magmatism to crustal growth should have been reduced (blue dashed lines). 
gneisses which dominate the Archean middle crust, although subduction related processes in combination with plume-related melting can also explain the origin of the TTG and growth of the early continental crust (e.g. Kemp and Hawkesworth, 2003; Zegers and van Keken, 2001).

While massive mantle melting caused by heads of mega-plumes or mantle overturns may have been the dominant mechanism at the early stages of the lithosphere formation, the proportion of the crust generated by plume-related oceanic plateau basalts probably decreased from the Archean to the present day (Condie, 1994) due to a secular decrease of mantle potential temperature (Campbell and Griffiths, 1992). Arc-related magmatism at convergent margins is expected to become dominant with mantle cooling and at present most of the continental crust is generated at arc settings (Fig. 6).

In case the dominant mechanism of continental crust production has changed during the evolution of the Earth, a systematic difference between the bulk compositions of the Archean and post-Archean crust with respect to key chemical indices or elemental ratios should be expected. However, isotope analysis of $\mathrm{Nb} / \mathrm{La}$ ratios, which are sensitive to the proportion of plume component in volcanic rocks, does not indicate that the contribution of plume-related magmas to crust generation has decreased since the Archean (Hofmann et al., 1986; Kemp and Hawkesworth, 2003). This conclusion is in apparent contradiction with the earlier mentioned results (Barth et al., 2000; Rudnick, 1995) and Figs. 4, 6.

\subsubsection{Growth rate of the continental crust}

There is an on-going debate on secular variations in growth and recycling rates of the crust and the lithospheric mantle, that is on the relative roles of different tectonic processes responsible for upwardand downward-directed material exchange, which apparently have not been constant through the Earth's evolution. Based on geological evidence, Dewey (2007) argues that downward-directed material exchange processes could have been most dramatic at the early stages of the Earth's evolution and it was not until the mid-Archean that crustal growth and crustal recycling became roughly compensated. Some geochemical evidence (Harrison et al., 2005) suggests that the early basaltic/komatiitic crust could have been entirely recycled back into the mantle in the Hadean $(>3.5 \mathrm{Ga})$.

There is a significant controversy in the estimates of the crustal growth rate from the Hadean until present. Global geophysical and geochemical evolutionary models suggest that crustal growth rate was $\sim 2-7 \mathrm{~km}^{3} / \mathrm{yr}$ during the Hadean and less than $2 \mathrm{~km}^{3} / \mathrm{yr}$ in the postHadean (<3.5 Ga) time (e.g. Armstrong, 1981; Dewey and Windley, 1981; Reymer and Schubert, 1984). Global and continent-scale isotope studies (although commonly significantly biased by sampling) shift the peak in crustal growth to the Archean-Paleoproterozoic (with a rate of $\sim 2-7 \mathrm{~km}^{3} / \mathrm{yr}$ ) and indicate low Phanerozoic growth rates, $<1 \mathrm{~km}^{3} / \mathrm{yr}$ (Allègre, 1982; McLennan and Taylor, 1982; Veizer and Jansen, 1985).

In contrast, some isotope studies (based on $\mathrm{Nd}$ and $\mathrm{U} / \mathrm{Pb}$ isotopes, and also significantly biased by sampling in the Laurasia continents) indicate episodic growth of continental crust: major peaks at 2.7-2.5 Ga, 1.9-1.7 Ga, and $1.1 \mathrm{Ga}$ with growth rates of juvenile crust of $\sim 6-7 \mathrm{~km}^{3} / \mathrm{yr}$ are separated by "quiet epochs" with the crustal growth rate of $\sim 1 \mathrm{~km}^{3} / \mathrm{yr}$ (Condie, 1998; McCulloch and Bennett, 1994). However, recent study based on ca. 13,800 integrated U-Pb and Hf-isotope analyses of (largely detrital) zircons suggests little episodicity in the formation of the continental crust (Belousova et al., 2010). It argues that ca.60\% of the present volume of the continental crust could have been separated from the mantle in the pre-Proterozoic time (before $2.5 \mathrm{Ga}$ ), whereas three major isotope peaks represent the time of major magmatic events and the associated crustal reworking. As noted by Condie (1998), the peaks at $2.7-2.5 \mathrm{Ga}, 1.9-1.7 \mathrm{Ga}$, and $1.1 \mathrm{Ga}$ are well correlated with global plate tectonic events such as assembly and dispersion of supercontinents and the time of the emplacement of giant dyke swarms (GDS) and komatiites (Fig. 6). Variations in volume of the present-day continental lithospheric mantle (that reflects its "survival rate", i.e. the difference between the growth rate and the recycling rate) also show similar peaks (Artemieva, 2006). Note that recent numerical simulations of mantle convection indicate that, due to higher mantle temperatures on the early Earth, the Precambrian plate-driven tectonics is likely to have been episodic, with pulses of crustal growth being a direct consequence of rapid plate motions (O'Neill et al., 2007b).

\subsection{Mafic magmatism: volcanism and intrusions}

\subsubsection{Geodynamic causes of mafic volcanism}

Basaltic magmatism plays an important role in melt generation on the terrestrial planetary bodies, and it can exist on the terrestrial bodies both with or without plate tectonics. Both in the absence and in the presence of plate tectonics, mafic magmatism can be caused by large-scale temperature anomalies in the mantle associated either with large- or small-scale mantle convection or with mantle plumes. An interaction of anomalously hot mantle with the upper thermal boundary layer (the lithosphere) can lead to its thermo-mechanical erosion, extension, and delamination (Davies, 1999; Ebinger and Sleep, 1998; Korenaga and Jordan, 2002). When plate tectonics operates, mafic magmatism can be a consequence of lithospheric subduction (Hoernle et al., 2008; Scholl and von Huene, 2007).

Basalt is the primary melt formed during mantle melting on Earth. The role of mantle melting and the associated mafic magmatism as a major mechanism of growth of new crust has been discussed above. Here we mention briefly another role that mafic magmatism and plutonism play in crustal (and lithosphere) evolution, that is to supply mantle material into the lithosphere by intrusions and volcanism in intraplate settings (Fig. 4a). However, the volume of mantle material transported into the crust in intraplate settings is small as compared to the voluminous magma generation at the plate boundaries (Fig. 4b). In the oceans, intraplate magmatism is responsible for formation of oceanic islands and ocean plateaus, that is "anomalous oceans" where the bathymetry does not follow the square-root of age dependence. The largest known oceanic large igneous province (LIP) is the Ontong-Java Plateau.

On the continents, which are the principal focus of our study, intraplate magmatism is responsible for epeirogenesis and crustal thickening (Kay et al., 1992; McKenzie, 1984; Mo et al., 2007). The most voluminous magmatic additions to the continental lithosphere include LIPs (with continental flood basalt provinces) and, mostly Precambrian in age, GDS (Mahoney and Coffin, 1987); both are formed by mantle melting caused by large-scale or small-scale mantle convection instabilities (King and Anderson, 1995; Yale and Carpenter, 1998). The Archean ages of the oldest known continental rifting events in the Kalahari craton and in Western Australia (e.g. Olsson et al., 2010; van Kranendonk et al., 2010) and the oldest giant mafic dyke swarms in the southern West Greenland (Nilsson et al., 2010) indicate that thermomechanical interaction between the ascending mantle material and the continental lithosphere has played an important role in the evolution of the continents since their very formation. Commonly mafic magmatism has a regional coverage; for example, small-scale convection instabilities termed "baby-plumes" were proposed to explain anorogenic Cenozoic igneous provinces in Europe (Lustrino and Wilson, 2007; Ritter and Christensen, 2007).

\subsubsection{The shape of magmatic intrusions}

Emplacement of high-density, mafic-ultramafic intrusions into low-density crustal rocks is widely observed in many tectonic settings. Geological observations as well as numerical modeling of intrusion of partially molten mantle rocks produced in a sub-lithospheric magmatic source indicate that geometry of intrusions critically depends on lithosphere rheology and ranges from dikes to deepseated balloon-shaped intrusions and to flat sills (Gerya and Burg, 2007). In case of cold lithospheric temperatures (typical for cratonic 


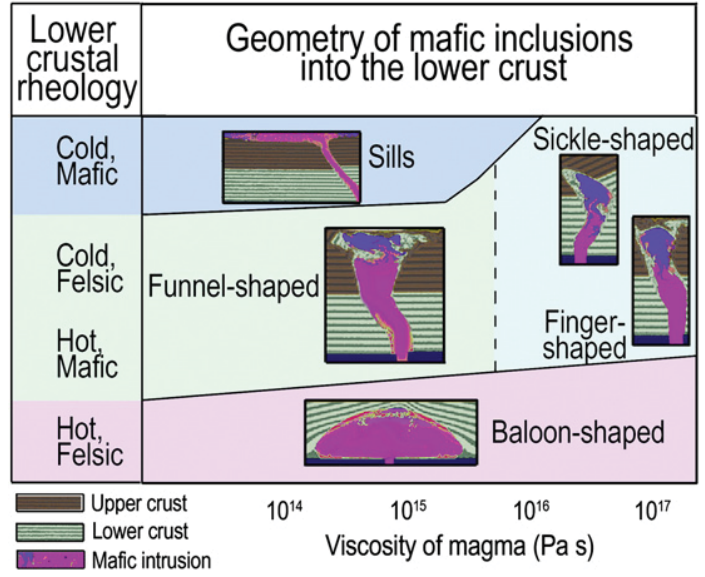

Fig. 7. Sketch showing the "stability fields" for mafic intrusions as a function of magma viscosity and rheology of the lower crust (based on numerical modeling of Gerya and Burg, 2007). "Cold" and "hot" crust correspond to Moho temperatures of $400{ }^{\circ} \mathrm{C}$ and $600{ }^{\circ} \mathrm{C}$, respectively, for the crustal thickness of $40 \mathrm{~km}$.

settings) and elasto-plastic crustal rheology, upward magma propagation is controlled by crustal faulting and makes finger-shaped dikes. Higher lithospheric temperatures favor lateral spreading of magma above the Moho with the formation of flattened shallow magmatic sills (Fig. 7). Such geometry of mafic intrusions is typical for the crust of Western Europe, but it can also be observed in continental rift zones and in some Precambrian terranes (e.g. large mushroomshaped plutons are imaged by the BABEL seismic profiles within the crust of the southern Swedish Baltic Shield (Korja and Heikkinen, 2005)).

Emplacement of basaltic magmas into the continental crust leads to its heating and consequent melting and can generate a large volume of silicic (felsic) magmas which may form granitic plutons (e.g. Coldwell et al., 2011; de Saint Blanquat et al., 2011; Guo et al., 2007; He et al., 2011) (Fig. 8). For example, a $70 \mathrm{~km}$ thick crust is produced in the Andes mostly due to sialic intrusions. Most of granitic rocks are formed by an interaction of basaltic melts with metamorphic rocks of supracrustal origin (Douce, 1999). Theoretical models indicate that a $500 \mathrm{~m}$ basaltic sill can generate the silicic magma layer with a thickness ranging from 300 to $1000 \mathrm{~m}$ depending on crustal temperatures (Huppert and Sparks, 1988). The time-scales for granitic magma generation in basalt-induced crustal melting are very short, hundreds to thousands of years, and even when large volume of magmas are produced, granite magmatism is a rapid process with timescales less than 100,000 years, irrespective of tectonic setting (Petford et al., 2000). In comparison, thermal relaxation of the continental crust takes place on the time-scale of tens of millions of years and the lifetimes of large silicic magma systems exceed millions of years. Progressive heating of the crust by basaltic intrusions may result in cycles of mafic-toprogressively silicic magmatism commonly observed in nature (de Saint Blanquat et al., 2011). Crustal heating by mafic intrusions also weakens the lithosphere and may lead to the lower crustal flow (Fischer, 2002). Being commonly associated with lithosphere extension and stretching (Le Bas, 1987), magmatism can lead to crustal thinning due to removal of the lower portions of lithosphere as observed in large parts of central and western Europe (Matte, 1991) (Section 2.5).

Recent seismic study of the Baikal rift zone indicates an important role of magmatic intrusions in continental rifting. In contrast to classical models of continental rifting, no crustal thinning is observed across the Baikal rift zone. The flat Moho can be explained by magma intrusions into the lower crust as indicated by the presence of the extremely high-velocity $(7.4-7.6 \mathrm{~km} / \mathrm{s})$ and highly reflective zone in the lower crust (Thybo and Nielsen, 2009). Observed seismic reflectivity can be explained by a layered sequence of strong reflectors (ca. $400 \pm 150 \mathrm{~m}$ thick with velocity contrast of $\sim 0.4 \mathrm{~km} / \mathrm{s}$ ) which occupy around $50 \mathrm{vol} . \%$ of the $13-\mathrm{km}$-thick lower crust. As a result, the estimated extension $\beta$-factor increases from 1.3 to 1.7 if the lower-crustal intrusions are taken into account. Similarly, seismic observations in the Devonian Dnieper-Donets rift zone in the southwestern part of the East European craton (Wilson et al., 2004) indicate a flat Moho and high crustal reflectivity, which can be explained by the presence of mafic intrusions in the lower crust that may form intermixed layering of primarily olivine- and pyroxene-rich rocks with layers of plagioclase-rich components (Lyngsie et al., 2007).

Intraplate magmatism is associated not only with mafic intrusions into the crust, but also with intrusions of basaltic magmas into the lithospheric mantle; many of them may never reach the surface. Infiltration of basaltic magmas into depleted cratonic lithosphere during largescale lithosphere-mantle interaction may lead to its compositional modification (melt-metasomatism) as evidenced by mantle-derived peridotite xenoliths from the Wyoming craton in North America and the Sino-Korean craton in China (e.g. Eggler et al., 1988; Griffin et al., 1998). Similarly, the proposed melt-metasomatism of the lithospheric mantle of the southern part of the East European craton (as evidenced, in the absence of mantle xenoliths data, by its post-Devonian subsidence history and by gravity and buoyancy modeling) may be associated with the Devonian plume beneath the Dnieper-Donets Rift and the PeriCaspian-northern Caspian depressions (Artemieva, 2003; Artemieva et al., 2006; Kaban et al., 2003).

\subsection{Subduction}

\subsubsection{Precambrian subduction}

A large number of numerical studies have investigated the parameter space that defines physical conditions on the terrestrial planets favorable for a plate tectonics regime. These studies demonstrated that three qualitatively different styles of mantle convection are possible: stagnant-lid, episodic, and mobile convection (plate tectonic regime) (Fig. 9). In the latter case, the negative buoyancy of the thermal boundary layer on the top of the mantle causes subduction and drives plate tectonics. The ratio of driving to resisting stresses defines the parameters critical for plate tectonics regime: when the convective

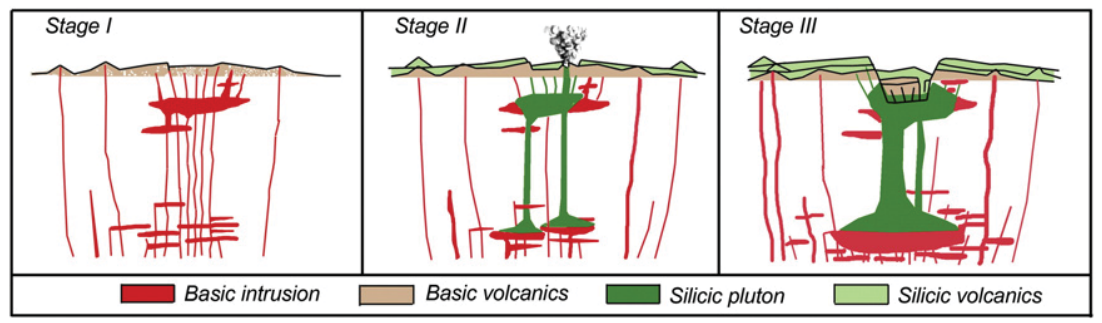

Fig. 8. Sketch showing evolutionary scheme for a formation of a silicic magma system by basalt emplacement into the crust (after Huppert and Sparks, 1988). At early stages most basalt reaches the surface. At the next stage, the crust becomes heated by basaltic magmas and its melting starts. Basalt, which is mostly trapped within the crust, does not form volcanic fields; silicic magmas which are episodically produced can either erupt or form shallow intrusions. At the final stage, a large volume of the crust reaches melting temperatures producing large volumes of silicic magma, while basaltic magmatism can still be present in the peripheral parts. 


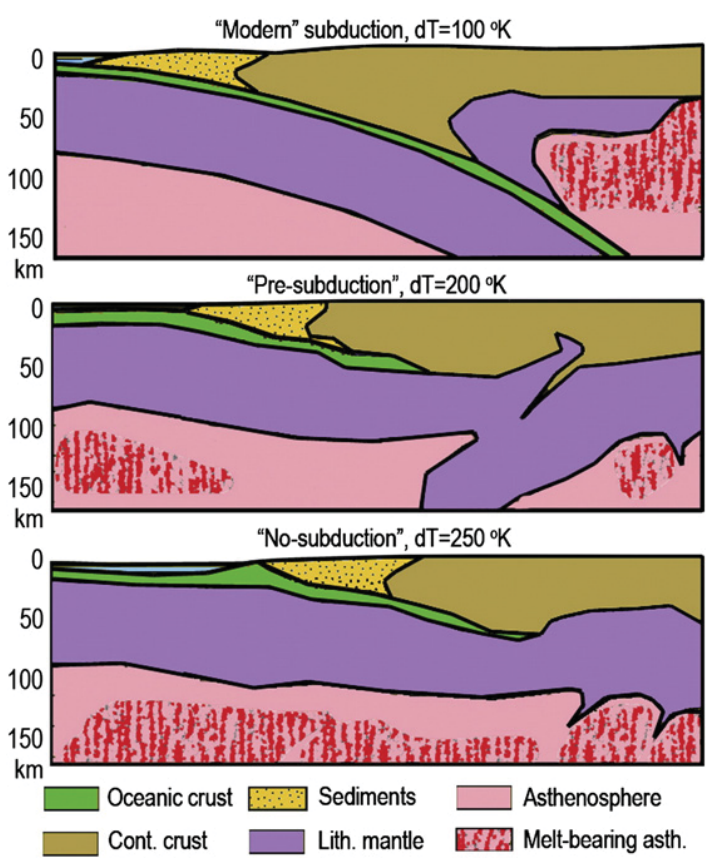

Fig. 9. Sketch illustrating three possible tectonic styles at convergent margins (based on numerical modeling of Sizova et al., 2010). At mantle temperature $\sim 250{ }^{\circ} \mathrm{C}$ higher than the present-day mantle, oceanic subduction does not develop (bottom figure). Mantle temperature $\sim 150-200{ }^{\circ} \mathrm{C}$ higher than the present-day mantle favors "pre-subduction" tectonic regime with shallow underthrusting of the oceanic plate under the continental plate (middle figure).

stresses produced due to the formation of sinking thermals exceed the intrinsic strength of the lid (the upper thermal boundary layer, or the lithosphere), the latter fails initiating subduction (Solomatov and Moresi, 1997). The convective viscous stresses depend on the vigor of mantle convection which is largely controlled by mantle temperature, whereas the resisting stresses are controlled by rheology of the overlying lid, which essentially depends on temperature and the presence of free water at the surface (Bird et al., 2008; O'Neill et al., 2007a). Since mantle temperatures and the concentration of heat producing elements are thought to be significantly different on the early Earth (Michaut and Jaupart, 2004; Nisbet and Fowler, 1983), the convection style on the early Earth could have also been different than today.

Numerical simulations examine the effect of high mantle temperatures on the style, and even on the possibility, of oceanic subduction in the Archean. In particular, due to increased mantle temperatures in the Archean, lithospheric stresses were lower, and could lead to episodicity of plate tectonics processes on the early Earth when rapid pulses of subduction were interspersed with periods of relative quiescence (O'Neill et al., 2007a). Other mantle convection simulations (Sizova et al., 2010) suggest that no subduction of oceanic plate could take place if mantle potential temperature (hypothetical temperatures of mantle adiabatically brought up to the surface without melting) was $250^{\circ} \mathrm{K}$ hotter than the present day mantle, whereas in case mantle temperature was only $\sim 150-200{ }^{\circ} \mathrm{C}$ above the present value, lithosphere deformation was characterized by "pre-subduction" tectonic regime with shallow underthrusting of the oceanic plate under the continental plate (Fig. 9). Thus, estimates of mantle potential temperatures in the Precambrian are critical for understanding of the style of oceanic subduction on the early Earth.

The best known temperature estimate is based on data for the Archean komatiites which was interpreted to indicate that the Archean mantle was at $1600-1800^{\circ} \mathrm{C}$ (Nisbet and Fowler, 1983), while potential temperature of the present-day mantle is commonly estimated to be between $1300{ }^{\circ} \mathrm{C}$ and $1450{ }^{\circ} \mathrm{C}$ (e.g. McKenzie et al., 2005). Early estimates of
Archean mantle temperatures have been questioned during the past decades. In particular, studies of MORB-like ophiolite suites and greenstone belts suggest that Archean mantle was at temperatures of $1430-1500^{\circ} \mathrm{C}$ (Abbott et al., 1994), while melting models for hydrous komatiites (Grove and Parman, 2004) and mantle convection models (Campbell and Griffiths, 1992) suggest that it could have been only $\sim 50^{\circ} \mathrm{C}$ hotter than the present mantle. In case the Archean mantle temperature was similar to the present day value, oceanic subduction could have started very early in the Earth's evolution. However, in case of high mantle temperatures in the Archean, no oceanic subduction existed on the Archean Earth, and the transition from "no subduction" to "pre-subduction" tectonic style has probably occurred at 3.2-2.5 Ga.

Even if oceanic subduction has operated already in the Archean, its geodynamic signature was significantly different from modern subduction (Abbott and Hoffman, 1984): (i) in contrast to steep postArchean subduction, Archean subduction was buoyant, flat, and shallow and (ii) melting occurred in the slab wedge rather than in the mantle wedge as in post-Archean tectonics. Secular variations in ridge length, plate velocities, and in the intensity of push-pull forces led to secular variations in the rate of material exchange between the lithosphere and the mantle in oceanic subduction zones. In particular, if Proterozoic plate velocities were slower than at present (Abbott and Menke, 1990), the lithosphere-mantle material exchange in the Archean-Paleoproterozoic could have been less vigorous than in Phanerozoic.

The oldest seismically imaged subduction zone is $\sim 2.69 \mathrm{Ga}$ (Calvert et al., 1995). It has been imaged by the LITHOPROBE seismic reflection studies in the Superior Province of the Canadian Shield as dipping reflectors extending $30 \mathrm{~km}$ into the mantle with the geometry similar to the reflectivity patterns in modern subduction zones and collisional sutures. There is no indisputable evidence for Archean subduction within the European continent. However, BABEL seismic profiles in the Baltic Sea and in the North Sea imaged several distinct dipping sub-Moho reflectors at the margins of the East European craton that extend 30-80 km into the mantle (Fig. 10) (Abramovitz et al., 1998; BABEL WG, 1990, 1993). These reflections dip at a $15^{\circ}$ to $35^{\circ}$ angle, are traced laterally over distances of up to $100 \mathrm{~km}$, and in two occurrences are accompanied by a sharp 5-7 km Moho offset. Their ages vary from Proterozoic (ca. 1.9 Ga in the northern part of the Bothnian Gulf and 1.6-1.4 Ga at the southern, Proterozoic, margins of the Baltic Shield) to Phanerozoic (ca. $440 \mathrm{Ma}$ for the reflector in the North Sea)

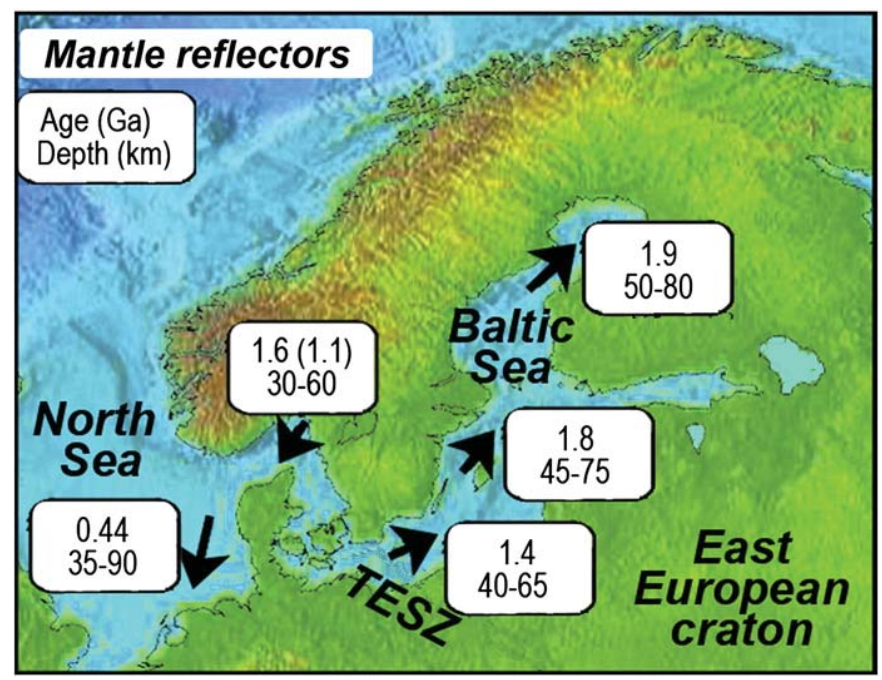

Fig. 10. Observations of subcrustal distinct dipping seismic reflectivity in the Baltic Shield (modified after Artemieva, 2011; Balling, 2000). Arrows show dip direction; the age and the depth range of subcrustal reflectivity is shown in boxes. These dipping seismic reflectors are interpreted as images of relict subduction zones and collisional sutures. TESZ $=$ Trans-European suture zone. 
and are constrained by the ages of known major tectonic events in the region.

\subsubsection{Modern oceanic subduction}

Lithosphere sinking in modern oceanic subduction zones is the most widespread and powerful process of both growth of the crust (see Section 2.2) and recycling of crustal/lithospheric material at active margins. Recent estimates indicate that $~ 80 \%$ of the thickness of the Ontong Java oceanic plateau has been subducted and recycled into the mantle if the past convergence rate between the plateau and the Solomon Island arc was the same as at present (Mann and Taira, 2004).

In modern subduction zones, basaltic oceanic crust of subducting slabs starts melting or transforms into denser eclogite phases at a relatively shallow depth. Thus oceanic subduction transports eclogite as well as serpentinite from the mantle wedge deep into the upper mantle. This process produces a large impedance-contrast boundary at slabmantle interface and an anisotropic boundary that are recognized in recent seismic surveys of the Cascadia subduction zone in western North America and Japan (Nikulin et al., 2009; Peacock, 2001). Eclogite addition to lithospheric mantle during oceanic subduction has been proposed to explain the presence of eclogites in cratonic kimberlites that are not in equilibrium with harzburgite (McGreggor and Manton, 1986). However, kimberlitic eclogites in cratonic settings can also be residues from the process of Archaean granitoid crust formation or crustal (lithosphere) delamination (Rollinson, 1997).

The bulk of the subducting oceanic lithospheric plate may reach, or even cross, the $660 \mathrm{~km}$ discontinuity, as indicated by seismic tomographic models (e.g. van der Hilst et al., 1997). Mantle flow and viscous drag may also have a strong effect on the penetration depth of slabs (Boutelier and Cruden, 2008). In some cases, the subducting plate may break, creating a slab window, that facilitates magmatism and promotes additions of new mantle material to the crust. This process is believed to operate along the Pacific coast of North America in Mesozoic and Cenozoic, where the subducting Farallon plate was detached and split into several microplates (Atwater and Stokes, 1998), that are imaged by seismic tomography models of the upper mantle of western USA (van der Lee and Nolet, 1997) and are reflected in wide-spread magmatism in the area (Breitsprecher et al., 2003).

\subsubsection{Continental collision and subduction}

Alike oceanic subduction, continental subduction is another efficient process of transporting lithospheric material back into the mantle. However, its initiation requires high stresses and commonly continental subduction is facilitated by a preceding oceanic subduction as it happened in several Phanerozoic orogens of Europe. In Cenozoic Europe, oceanic subduction processes are thought to be the forerunner and active carrier of the subducting continental plates in the Alps, Carpathians, Pyrenees, and beneath Iberia. Numerous regional P-wave and S-wave refraction and tomography models indicate the presence of several subduction zones in the Alpine-Mediterranean region that extend down to a depth of 200-250 km (e.g. Cavazza et al., 2004; Piromallo and Morelli, 2003). High-resolution teleseismic P-wave tomography of the Alps (Lippitsch et al., 2003) suggests the existence of two subduction zones: beneath the eastern Alps, the continental Adriatic lower lithosphere subducts northeastwards beneath the European plate, whereas beneath the western and central Alps, the continental European lower lithosphere steeply subducts southeastwards beneath the Adriatic microplate. Localized linear highvelocity blocks in the upper mantle interpreted as subducting slabs have been imaged by seismic tomography beneath the LigurianTuscany and southern Iberia (Blanco and Spakman, 1993).

A $30 \mathrm{~km}$ wide block extending down to a depth of ca. 80-100 km with $2 \%$ lower velocities, which has been imaged by regional P-wave tomography models beneath the central and eastern Pyrenees, has been interpreted as subduction of the lower crust of Iberia (Sibuet et al., 2004; Souriau and Granet, 1995); eclogitization of the lower crust during its subduction produced weak negative residual gravity anomalies observed in the Pyrenees (Vacher and Souriau, 2001). Similarly, a linear belt of positive residual gravity anomalies along the TESZ suggests the presence of an ancient subducting slab beneath the western margin of the EEC as indicated by a regional S-wave tomography model (Nolet and Zielhuis, 1994; Zielhuis and Nolet, 1994). However, there is no seismic sign of a subducting slab beneath the Caucasus (Artemieva et al., 2006).

In contrast to oceanic subduction, subducting continental plates do not reach the depth of subducting oceanic plates because of an early start of melting and a smaller slab pull. In the early days of plate tectonics, the process of continental subduction was not even considered to be possible because of buoyancy problems associated with low-density continental crust. Presently, about 20 cases of Phanerozoic continental subduction have been confirmed worldwide by the presence of ultrahigh-pressure metamorphic rocks (UHPM) near continent-continent collision zones, where rocks of the continental crust have been subjected to pressures of up to $5 \mathrm{GPa}$ (i.e. transported to a depth of more than $150 \mathrm{~km}$ ). Even depths as great as $300 \mathrm{~km}$ have been inferred for subduction of continental material from samples of garnet peridotite that show the presence of metamorphic microdiamond and coesite inclusions (Kaneko et al., 2000; Ye et al., 2000). In particular, UHPM rocks of the Kokchetav Massif of Kazakhstan indicate subduction of Precambrian crustal protoliths which, at around $530 \mathrm{Ma}$, were transported to depths of $\sim 200 \mathrm{~km}$ (pressures of $\sim 7 \mathrm{GPa}$ ). Subsequent exhumation of these UHPM rocks can occur by different tectonic mechanisms, for example by wedge extrusion (Boutelier et al., 2004; Kaneko et al., 2000).

There is no undisputable evidence for the operation of continental subduction in the early-mid Precambrian. Due to a greater buoyancy of the continental lithosphere in the Archean-Paleoproterozoic, subduction of oceanic lithosphere, but not of continental lithosphere, is a more likely process to operate on the early Earth. Seismic reflections in the cratonic mantle commonly interpreted as relict subduction zones within the continental lithosphere (BABEL WG, 1990; Warner et al., 1996) (Fig. 10) could have rather been formed by oceanic subduction during closure of paleooceans. Note, however, that in the Baltic Sea a dipping seismic reflector crosses the Moho and in the same place sub-Moho Vp velocities change from 7.8 to $8.2 \mathrm{~km} / \mathrm{s}$ over a distance of ca. $25 \mathrm{~km}$, suggesting the operation of continental subduction in Paleoproterozoic (Abramovitz et al., 1997).

\subsubsection{Recycling rate at subduction zones}

While oceanic slabs have a large variety of dip angles and penetration depths (Anderson, 2007), not much is known about the shape of subducting continental plates. The collision of the Indian and Asian plates provides the most powerful and the best studied example of the continental subduction (e.g. Kind et al., 2002; Molnar and Tapponier, 1975; Wittlinger et al., 2004). Seismic images suggest that, after the subduction of large parts of the Tethyan oceanic plate, the continental lithosphere of the Indian subcontinent has been (and still is) pushed below the Himalaya and Tibet down to a $200-250 \mathrm{~km}$ depth in the mantle (e.g. Huang et al., 2003). If the convergence rate (its part not absorbed by thrusting along the Himalayas front) has been constantly similar to the present-day rate of $\sim 5 \mathrm{~cm} /$ year, about $2500 \mathrm{~km}$ of the Indian plate with a lithospheric thickness of $\sim 200 \mathrm{~km}$ may have been recycled in the subduction zone beneath the Tibet over the past $\sim 50 \mathrm{My}$.

Despite this huge number, the recycling rate of the continental lithosphere is much smaller than of the oceanic lithosphere. The continental lithosphere is thicker, buoyant, and commonly tectonically protected from subduction zones due to its location within the continental interior. Recent geochemical constraints suggest that no more than $30 \%$ of the modern mass of the continents has subducted into the mantle during the entire Earth's history. Furthermore, about 50-70\% 
of the subducted continental material has been emplaced back either as magmatic products into the continental lithosphere or as metamorphic material into the lower crust (Coltice et al., 2000). In contrast, according to geophysical data, a volume of continental crust equal to its present-day volume could have been recycled since $2.5 \mathrm{Ga}$ in case recycling rates in modern subduction zones are representative of the past rates (Scholl and von Huene, 2007). Presently, the rate of crustal recycling at non-accreting margins is $\sim 1.3 \mathrm{~km}^{3} /$ year which is about an order of magnitude higher than at accreting margins (compare with Fig. 4b). The recycling rate of the entire lithospheric plate can be several times higher than for the crust but commonly it is not included into estimates of recycling rates.

Subduction of continental lithosphere, although less effective than oceanic subduction and more limited regionally, plays an important role in the chemical and mineralogical modification of the upper mantle. The amount of subducted crustal material depends on the stress regime and the rheology of the colliding lithospheric plates. Subducted crustal material may mobilize the asthenosphere and trigger magmatism as observed in Tibet (Mo et al., 2007), but mantle material is not always quickly returned to the surface. We discuss later the tectonic similarity between the modern Tibet and the Variscan Europe as proposed by different authors (Le Pichon et al., 1997; Menard and Molnar, 1988), and discuss whether subduction-related processes could produce Paleozoic regional intrusions of basaltic magmas into the lower crust of west/central Europe.

\subsection{Thermo-mechanical recycling of the lithosphere}

\subsubsection{Lithosphere delamination}

Gravitational (or Rayleigh-Taylor-type) instability, which develops at an interface between two viscous materials of different densities when the lighter material underlies the heavier material, is responsible for lithosphere delamination. The process which has long ago been proposed to explain the Cenozoic uplift of the Colorado Plateau (Bird, 1979) has recently been imaged seismically (Levander et al., 2011). Importantly, it is likely that lithosphere delamination always includes delamination of both the lower crust and the lithospheric mantle, for example due to viscous coupling between the crust and mantle as proposed for the on-going removal of the dense batholithic root beneath the southern Sierra Nevada mountains in California (Zandt et al., 2004). In some cases, lithosphere (crustal) delamination may result in magmatism and epeirogenesis (Kay and Kay, 1993) such as proposed for some parts of the Andes (McGlashan et al., 2008).

A density inversion that causes gravitational instability may have thermal or compositional origin, such as produced by pondering of hot mantle material beneath the lithospheric base, lithosphere thickening beneath orogenic belts, and phase transitions in the crust (Fig. 11, see below). Rheologically weak lithosphere and low convergence rate favor development of the Rayleigh-Taylor instability in collisional settings, where convergence is accommodated by pure shear thickening. As an orogen is formed, the entire lithosphere is thickened, and a cold and dense lithospheric root sticks down into the hotter asthenosphere, creating lateral temperature instability. It drives convective flow which can remove (delaminate) the lower portions of the thickened lithospheric mantle. Similarly, the presence of density inversion also causes delamination of negatively buoyant lithospheric material, which is swept into descending drips or blobs. To maintain the mass balance, hotter mantle material replaces delaminated lithosphere, causing adiabatic decompressional melting and triggering magmatism.

The efficiency of lithosphere delamination by Rayleigh-Taylor-type instability is controlled by lithosphere viscosity. Depending on the thickness of the lithospheric root, lithosphere delamination requires lower crustal viscosity between $10^{20}$ to $10^{23} \mathrm{~Pa}$ s if viscosity of the upper crust is $10^{23} \mathrm{Pas}$ (Schott and Schmeling, 1998). Numerical
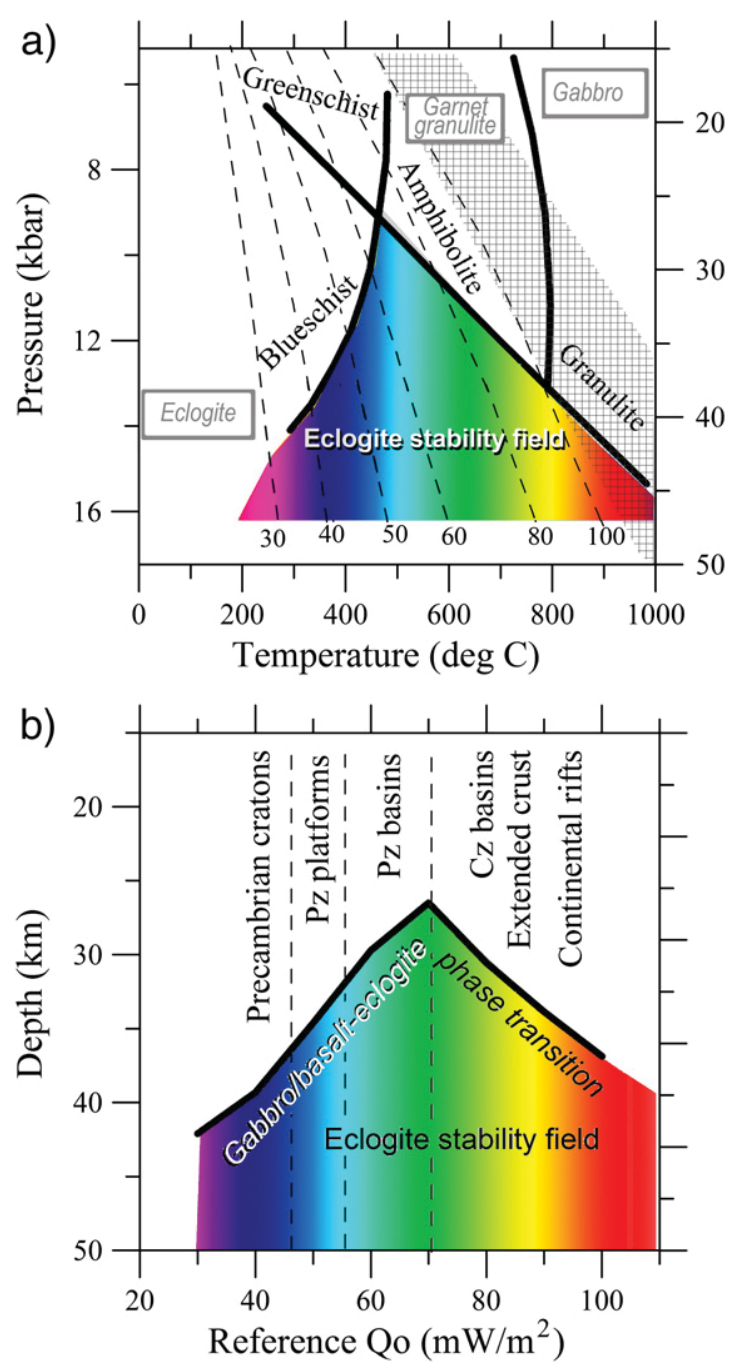

Fig. 11. Gabbro/basalt-eclogite phase transitions in the crustal rocks. Rainbow shadingeclogite stability field, colors refer to lithospheric temperatures (purple for cold, red for hot). Pressure-depth conversion is made assuming crustal density of $2.90 \mathrm{~g} / \mathrm{cm}^{3}$. (a) Bold black lines-phase diagram (after Spear, 1993). Shaded area and gray boxesextrapolated stability fields of eclogite, garnet granulite, and pyroxene granulite-gabbro based on experimental data for the quartz tholeiite composition (Ringwood and Green, 1966). Thin dashed lines-typical continental reference geotherms (Pollack and Chapman, 1977); numbers-surface heat flow in $\mathrm{mW} / \mathrm{m}^{2}$. (b) Depth to gabbro/basalt-eclogite phase transition (thick gray line) in different continental settings plotted versus continental reference geotherms labeled in heat flow values (after Artemieva, 2011). Tectonic provinces are marked on the top in accordance with typical heat flow values. Gabbro/basalt-eclogite phase transition limits crustal thickness to $40-45 \mathrm{~km}$ in cold stable platforms and to $\sim 30 \mathrm{~km}$ in Phanerozoic basins.

modeling of the development of convective instability associated with mechanical thickening of cold, dense lithosphere beneath mountain belts indicates that only the lower $50-60 \%$ of the lithosphere may be delaminated in case of dry olivine rheology but more than $80 \%$ of the lithosphere in case of wet olivine rheology (Houseman and Molnar, 1997). Removal of the lithospheric root in mountain belts built by crustal thickening adds potential energy to the lithosphere and causes collapse of orogens by normal faulting and horizontal crustal extension. Commonly this process starts within $\sim 30$ My after the end of the crustal thickening.

Lithosphere delamination is proposed to drive the Cenozoic tectonic evolution of the Colorado Plateau (Bird, 1979; Levander et al., 2011), the Sierra Nevada (Harig et al., 2008), the southern Puna plateau of the Andes (Kay and Kay, 1993), Tibet and Himalaya (England and Houseman, 1989; Turner et al., 1996). In Europe, lithosphere delamination can play an important role in Cenozoic geodynamics of 
the Vrancea zone in the Carpathians and the Alboran Sea in western Mediterranean (Houseman and Molnar, 1997). The presence of, roughly cylindrical in shape, drip-structures between $\sim 60$ and $300 \mathrm{~km}$ depth with high seismic velocities is imaged beneath both regions and is interpreted, although not univocally, as delaminated lithosphere (Calvert et al., 2000; Koulakov et al., 2010; Wortel and Spakman, 2000). The process may have also played an important role in the evolution of the Variscan lithosphere (see Section 3).

\subsubsection{Delamination of the lower crust: geochemical evidence}

Average major element composition of the continental crust (see Section 2.2) is directly related to crust-mantle material exchange processes. In particular, composition of the upper crust corresponds to only 14\% partial melting of average new basaltic crust (Hawkesworth and Kemp, 2006a), whereas typically the upper crust makes $\sim 25-35 \%$ of the volume of the continental crust. This misbalance implies that a significant amount of the lower crust (with the composition of a new continental crust), from which the upper crustal layer was produced, is missing and was recycled into the mantle. The residence time of elements in the lower crust can be $\sim 5$ times shorter than those in the upper crust (Hawkesworth and Kemp, 2006b).

The mechanism of lower crustal recycling may be gravitational instability of the missing lower crustal portions that originally could extend down to a $100 \mathrm{~km}$ depth as required by volume balance. Elevated P-T conditions typical for depths of 50-100 km favor phase transitions that produce heavy minerals, such as garnet, and thus promote recycling of the lower crustal material into the mantle (Kay and Kay, 1991). Delamination of lower crustal material should be more dramatic in those tectonic settings where crustal growth is most rapid, that is at convergent margins.

\subsubsection{Delamination of the lower crust: geophysical perspective}

Gravitational instability develops when continental lithosphere is in unstable mechanical equilibrium because one of its upper layers becomes denser and heavier then the underlying layer. Experimental studies indicate that throughout large regions of the normal continental crust eclogite is more stable than gabbro and garnet granulite (Ringwood and Green, 1966). Phase transition of gabbro/basalt to eclogite in a deep mafic crust can be responsible for delamination of the lower crust (and in some cases, even of the upper crust, Di Luzio et al., 2009) since it can produce a significant density inversion (densities and Vp seismic velocities of gabbro/basalt and eclogite at the lithostatic pressure and temperatures typical of the lower crust are $\rho \sim 2850-3000 \mathrm{~kg} / \mathrm{m}^{3}, \quad \mathrm{Vp} \sim 6.2-7.0 \mathrm{~km} / \mathrm{s}$ and $\rho \sim 3500 \mathrm{~kg} / \mathrm{m}^{3}$, Vp 7.6-8.1 km/s, respectively (Christensen and Mooney, 1995)). Since the transition from gabbro [plagioclase + pyroxene \pm olivine \pm spinel] to eclogite [garnet + pyroxene \pm quartz] occurs through the garnet granulite [garnet + pyroxene $(s)+$ plagioclase] (Fig. 11a), the increase in density and seismic velocity from gabbro to eclogite (caused by an increase in the proportion of garnet and a decrease in the proportion of plagioclase with a pressure increase) is uniformly smeared throughout the garnet granulite transition interval (with $\rho \sim 3150 \mathrm{~kg} / \mathrm{m}^{3}$ and $\mathrm{Vp} \sim 6.8-7.2 \mathrm{~km} / \mathrm{s}$ at lower crustal P-T conditions).

Given that eclogitic material is denser than the underlying mantle peridotite (density of the latter is $3300-3400 \mathrm{~kg} / \mathrm{m}^{3}$ ), the densified lower crust starts sinking, for example by crustal "dripping" into the mantle (Gögüs and Pysklywec, 2008), when a significant amount of eclogite is formed. Thus, delamination of the lower crust limits the thickness of the (petrological) continental crust by the depth where the lower layer transforms into dense eclogite- or garnet-pyroxenite facies.

Gabbro/basalt-eclogite phase transition typically starts at depths 30-45 km (Mengel and Kern, 1992) with significant regional depth variations due to a strong temperature-dependence of the reaction (Fig. 11). However, the actual P-T stability field of the system at low temperatures is unknown because the rate of gabbro/basalt- eclogite transformation is very slow and also strongly temperaturedependent. For this reason, laboratory experiments have been made at temperatures T $>800-1000{ }^{\circ} \mathrm{C}$ (Ito and Kennedy, 1971; Ringwood and Green, 1966), and then extrapolated to lower temperatures. Although the real rate of the transition is unknown, it is sensitive to both temperature and the presence of fluids, so that even trace amounts of water may lead to rapid eclogitization (Austrheim et al., 1997), such as expected in subducting slabs where metamorphic transformation of the basaltic and gabbroic oceanic crust to eclogite occurs on the order of $10^{6}-10^{8}$ years, that is at distances of $10-100 \mathrm{~km}$ along the slab for typical subduction rates (Ahrens and Schubert, 1975). The composition of basalts has some effect on the phase transition pressures and temperatures; for example experimental studies indicate a pressure difference of up to $5 \mathrm{kbar}$ for the gabbro-garnet granulite transition in alkali olivine basalts and tholeiite basalts (Ringwood and Green, 1966).

In cratonic regions with exceptionally cold lithospheric temperatures (Fig. 5), the basalt-eclogite transition is expected to occur only at depths $>40-45 \mathrm{~km}$ (Fig. 11b). These values are in a perfect agreement with global seismic observations that show that crustal thickness in Precambrian shields is limited to $\sim 50-55 \mathrm{~km}$ with an average thickness of $\sim 40-45 \mathrm{~km}$ : deeper crustal roots become gravitationally unstable with phase transition advance and are mechanically delaminated. In some cases, some eclogite material can still be present in the deeper parts of the crust, but it would be seismically indistinguishable from the mantle material (in particular, because not $100 \%$ of the lower crustal rocks transforms to eclogite). Due to the extreme slowness of the gabbro-eclogite phase transition at low temperatures, thick seismically-distinguishable metastable crustal roots may be occasionally preserved in cold and dry intracratonic environments, like in central Finland, where the crustal root extends down to 55-60 km, well into the eclogite stability field. Lower crustal xenoliths from the Kola Province of the Baltic shield confirm the presence of variably retrogressed and metasomatized eclogites at depths between 30 and $48 \mathrm{~km}$ (the deepest sampled depth) (Downes, 1993). Although it is unknown if gabbro can remain metastable for a billion years, the time scale of processes in Precambrian terranes, solid state diffusion cannot produce the transition in geologically meaningful times under low temperatures $\left(<600-800^{\circ} \mathrm{C}\right)$ and at anhydrous conditions that are thought to be typical of the cratonic lithosphere (Ahrens and Schubert, 1975).

At high crustal temperatures, typical for Phanerozoic regions, gabbro/basalt-eclogite phase transition requires time on the order of million years (Artyushkov, 1993). For this reason, mafic crustal roots deeper than $40-45 \mathrm{~km}$ in young mountain ranges are transitory, metastable features that are either being formed during on-going continental collision/subduction or existing as long as the age of the newly-formed crustal roots is younger than the time-scale of the gabbro-eclogite phase transition. Additionally, the timing of lower crustal eclogitization may be controlled not only by crossing of the phase transition depth, but rather by the time when fluids are introduced into the anhydrous system (Austrheim et al., 1997). In particular, crustal doubling without eclogitization may exist in collisional orogens with a dry crust such as proposed for the southernmost Tibet where low seismic $\mathrm{Vp}(\sim 6.3 \mathrm{~km} / \mathrm{s})$ in the underthrusting Indian crust do not indicate crustal eclogitization (Zhao et al., 1993).

Due to a peculiar shape of gabbro/basalt-eclogite phase transition on P-T diagram, metamorphism can start already at $~ 30 \mathrm{~km}$ depth in young platforms with moderate crustal temperatures, such as in the Variscan Europe (Fig. 11b). A surprisingly uniform thickness of 28-32 km typical of the European Variscan crust (see Section 3.2.4) is in a striking accord with the depth of eclogitization; yet other explanations for the thin Variscan crust are also plausible. In contrast, due to the shape of basalt stability field, young tectonic regions with high lithospheric temperatures may have stable lower crustal roots down to a $35-40 \mathrm{~km}$ depth. 


\subsubsection{Thermal and thermo-mechanical erosion}

Two other thermo-mechanical mechanisms to destroy (and delaminate) the lithosphere include (i) thermal erosion by mantle plumes or convection and (ii) thermo-mechanical erosion by stirring and friction (basal drag) associated with relative movement of the lithosphere over the underlying mantle (e.g., Artemieva and Mooney, 2002; Sleep, 2003). Similar to gravitational instability, the efficiency of these processes strongly depends on lithosphere rheology. Particular physical and chemical conditions required for preservation of 2.5-3.0 Ga old cratonic lithospheric roots that may extend down to at least $250-300 \mathrm{~km}$ depth (Artemieva and Mooney, 2001; Kustowski et al., 2008; Lévy et al., 2010) have been a subject of numerous studies. Numerical models of mantle convection indicate that the continental lithosphere can sustain against convective erosion if lithosphere viscosity is three orders of magnitude higher than that of the convective mantle (Lenardic and Moresi, 1999; Shapiro et al., 1999). Dry depleted composition of cratonic lithosphere as proposed by Pollack (1986) can provide the high viscosity contrast required for the cratonic lithosphere to maintain large equilibrium thickness (Doin et al., 1997). Thermo-mechanical erosion is thought to be the cause of the missing cratonic lithosphere beneath the North China craton (Fan et al., 2000). However, thermal erosion of the continental lithosphere contributes not only to recycling of crustal material into the mantle (Gao et al., 2004; Xu et al., 2004), but causes mafic magmatism which leads to crustal growth (Section 2.3).

\section{Peculiarities of crustal velocity structure in central and Western Europe}

\subsection{Making Paleozoic Europe}

To facilitate the following discussion, we start with a brief summary of the European tectonic evolution in the Paleozoic. The Caledonides form the oldest of the Paleozoic mountain belts in Europe (Fig. 12). After the closure of the Iapetus Ocean, a complex continent-continent triple plate collision (Baltica, Laurentia, and Avalonia) began in the Ordovician-Silurian time (McKerrow et al., 1991) (Fig. 13a). Large parts of west-central Europe, including southern Great Britain, the southern North Sea, and parts of northern Germany (the German-Polish Caledonides) are thought to be remnants of East Avalonia (Thybo et al., 2002) (Figs. 12, 14). The Caledonian continent-continent-collision, that lasted until 400-390 Ma, was accompanied by significant continental subduction as indicated by seismic data and the presence of numerous eclogites and ultrahigh pressure (UHP) rocks in Norway (Boutelier et al., 2004); some of these rocks were exhumed from a depth of more than $100 \mathrm{~km}$ (Johnston et al., 2007). The collision resulted in the Caledonian-Appalachian Orogeny as a result of which the Caledonian foldbelt was formed in western Europe and East Greenland and the Appalachian orogen was formed in eastern North America (Fig. 14).

The Variscan Orogen is a broad, 500 to $1000 \mathrm{~km}$ wide, mountain belt which stretches NE-SW across most of west-central Europe for about $3000 \mathrm{~km}$ and runs from Portugal and Spain to Poland and England (Fig. 15a). It was formed mainly between 430 and $280 \mathrm{Ma}$ as a result of the closure of the Rheic Ocean and the subsequent collision of the Gondwana and Laurasian continents (Fig. 13b). At around $400 \mathrm{Ma}$ Avalonia collided with Baltica (Fennoscandia and Denmark)/ Laurentia (North America, Greenland and northern Britain), forming the new supercontinent Laurasia (Lliboutry, 1999; McKerrow et al., 1991; Tanner and Meissner, 1996).

Although it is clear that oceanic and, perhaps, continental subductions played a key role at the initial stages of the formation of the Variscan orogen, how the convergence in the Variscan orogeny really took place is much debated. It is unknown if it resulted in the formation of huge plateaus and high mountain ranges or only in relatively small mountain belts (Franke, 2006; Oncken, 1998). Strong seismic anisotropy in the lithosphere and some mantle xenoliths indicate a complicated pattern in the closure of oceanic domains and the consequent formation of the Variscan orogen and the associated subduction zones (Babuška et al., 2002; Christensen et al., 2001; Downes, 1993; Fuchs and Wedepohl, 1983; Plenefisch et al., 2000; Wilson et al., 2004). The total crustal shortening during the Variscan orogeny exceeds $600 \mathrm{~km}$. The terranes of Proterozoic to Carboniferous ages, including the Armorican, Iberian, Bohemian, Ardennes, and Massif Central (Fig. 15b) were deformed and partly metamorphosed. Large volumes of granitoides have been emplaced between 370 and 280 Ma (Matte, 1986); a few eclogitic rocks were found in the Saxothuringian sub-terrane (Franke, 1994). The present-day Variscan structures are represented by the Rhenohercynian, Saxothuringian and Moldanubian sub-terranes, separated by subparallel NE-SWstriking sutures (Fig. 15a). The sub-terranes have distinctly different lithospheric structure which is discussed in the next section.

\subsection{Crustal thickness in Europe}

We next review the major characteristics of the Paleozoic crust of western Europe to discuss how it could have been formed and which of the crust-mantle material exchange processes played the dominant role in its structural evolution. A detailed review of crustal structure of Europe is outside the scope of the present study. Recent summaries can be found in Pavlenkova (1996), Ziegler and Dèzes (2006), Artemieva (2007), Tesauro et al. (2008), Artemieva and Thybo (2012). The general tectonic evolution and the present-day structure of the European lithosphere is summarized in Blundell et al. (1992) and Artemieva et al. (2006). Here we would like to emphasize only few points related to the present discussion, with an emphasis on the Paleozoic crust.

Typical continental crust has an average thickness of ca. $40 \mathrm{~km}$ (Christensen and Mooney, 1995). Although this number produced by worldwide averaging over tectonic provinces with diverse tectonic origin should not necessarily be meaningful, it provides some reference frame for global comparisons. In general, any continental crust significantly thinner or thicker than $40 \mathrm{~km}$ is usually considered as "anomalous". In this section we demonstrate that most of the continental crust in Europe is "anomalous", either in terms of comparisons with a global average of ca. $40 \mathrm{~km}$, or with expectations coming from comparisons with tectonic analogues of the same ages, or both. In particular, continental crust with a $40 \mathrm{~km}$ thickness is largely absent in Europe (Fig. 16).

\subsubsection{Crustal roots in young collisional orogens}

Deep crustal roots are commonly present beneath young collisional orogens worldwide. In Europe they have been seismically imaged beneath the Alps, the Carpathians, and the Pyrenees where they are parts of subducting continental slabs (Artemieva et al., 2006 and references therein). The formation of these orogenic belts and associated subduction zones is related to the convergence of the Eurasian and African plates which resulted in the collision of the Adriatic and the Iberian terranes with the Variscan continent, producing the main uplift of the Alpine belt at $\sim 23 \mathrm{Ma}$ (Castellarin and Cantelli, 2000; Schmid et al., 1996). Although the pre-orogenic history of the Alps and the Pyrenees is different, the deep seismic structure looks similar and both mountain belts have developed deep crustal roots, extending down to 55-60 km (Behm et al., 2007; Lippitsch et al., 2003; Pfiffner, 1990; Willingshofer and Cloetingh, 2003).

Beneath the Alpine mountain belt, the lower crust is felsic (with low P-wave seismic velocities) and seismically laminated, apparently as a heritage of the subducted Variscan crust (see below) (Figs. 17a, 18). The downward curvature of the lower crust towards the center of the mountain belt has been interpreted as an indicator that its age is older than the last orogenesis (TRANSALP Working Group, 2002). In counter play with downward material transport by subduction 


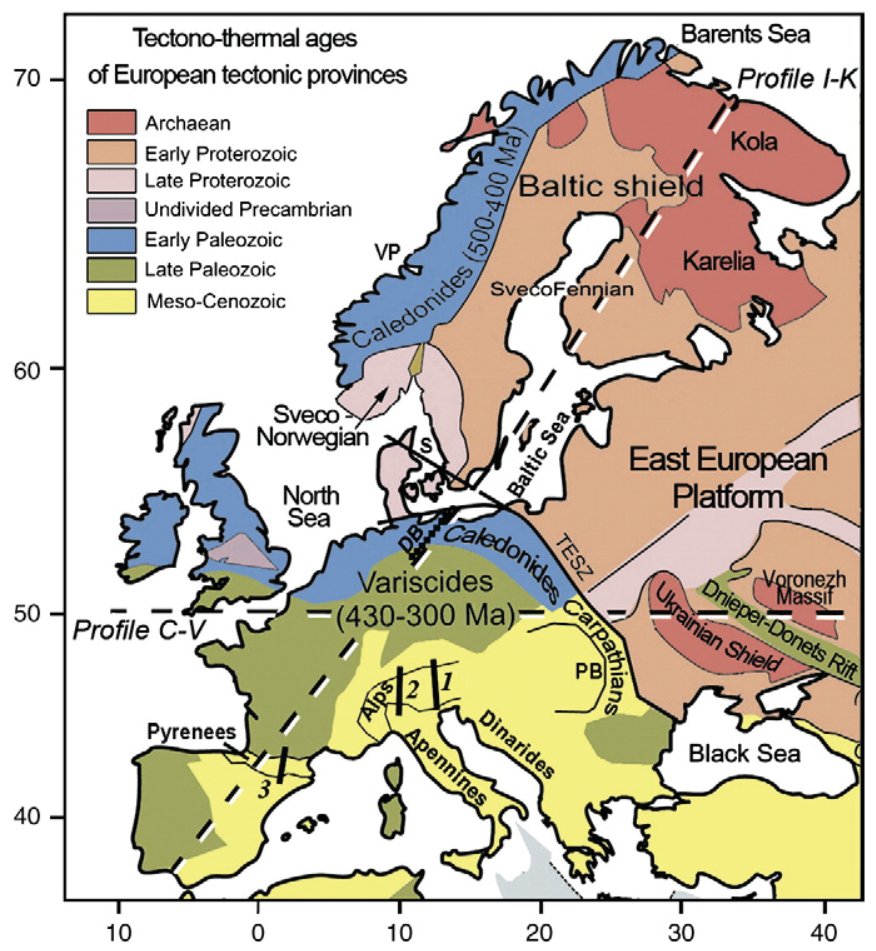

Fig. 12. Tectonic map of Europe (modified after Artemieva et al., 2006). Dashed lines-crustal cross-sections discussed in Fig. 19 (profile C-V follows a $50 \mathrm{~N}$ latitude from the Atlantic margin (Cornwell) to the Voronezh massif; profile I-K extends from the Iberian massif to the Kola province). Black diamonds-DEKORP/Basin profile (see Fig. 19e). Black thin linesseismic profiles discussed in Fig. 18 (1-TRANSALP, 2-Swiss, 3-ECORS). TESZ = Trans-European Suture Zone, VP = Voring Plateau, PB = Pannonian Basin, $\mathrm{S}=\mathrm{Skagerrak}$ area.

processes, magmatic activity in the mountain belts provides some upward material transport as well. The famous Ivrea body in northern Italy is an intrusive mafic complex with P-velocities of more than $7.4 \mathrm{~km} / \mathrm{s}$. The body reaches the surface where it is surrounded by "hybrid" rocks which have apparently assimilated some crustal material during their ascend. The composition of the magmas suggests they originated in the upper mantle with perhaps some input from the lowermost crust (Sinigoi et al., 1991; Voshage et al., 1990).
In the Carpathians, the origin of which is also, at least in part, associated with the African-Eurasian plate collision so that some authors consider them to be an eastward extension of the Alps (Cloetingh et al., 2004), the subduction-related orogenic crustal root is less pronounced than beneath the Alps and the Pyrenees with Moho at 39-43 km depth (Sroda et al., 2006). Today the Carpathians display a wide range of strong crust-mantle interaction processes, which include a complex interplay between the eastward extrusion of the

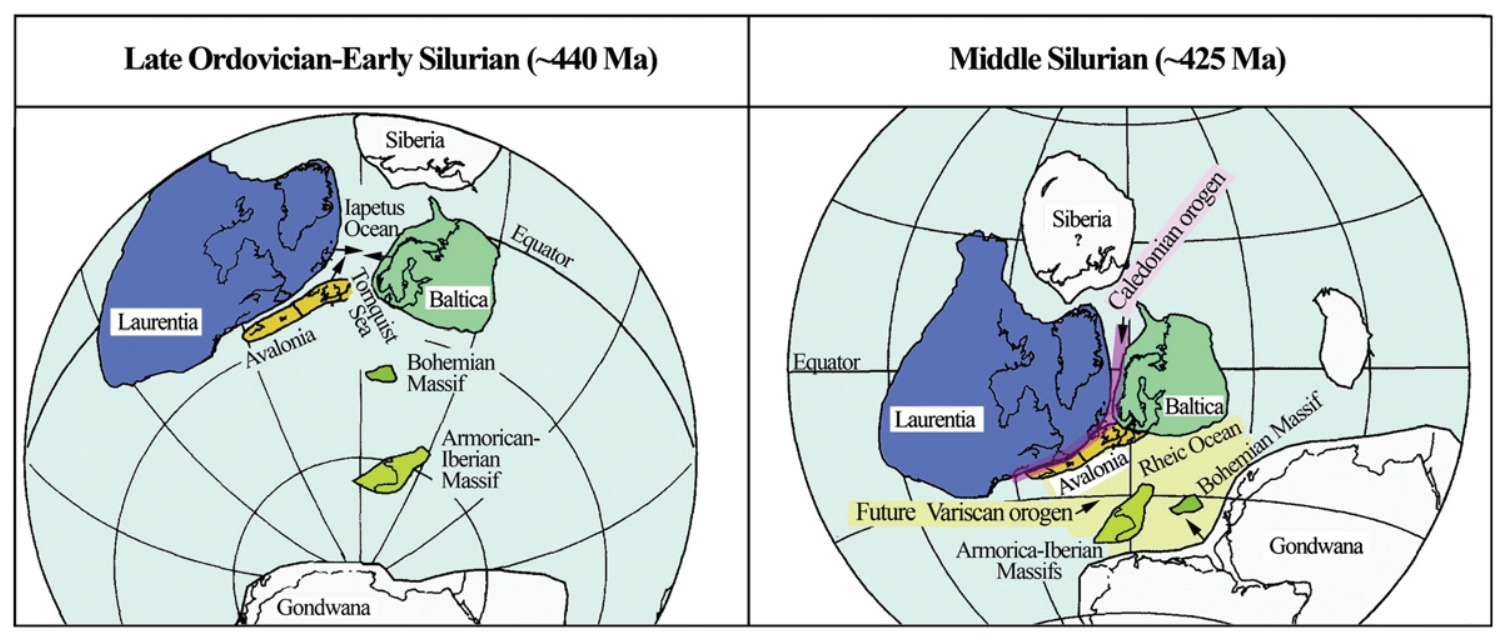

Fig. 13. Sketch illustrating Paleozoic assemblage of Laurasia and the formation of the Caledonian and the Variscan orogens (after Torsvik et al., 1996). 


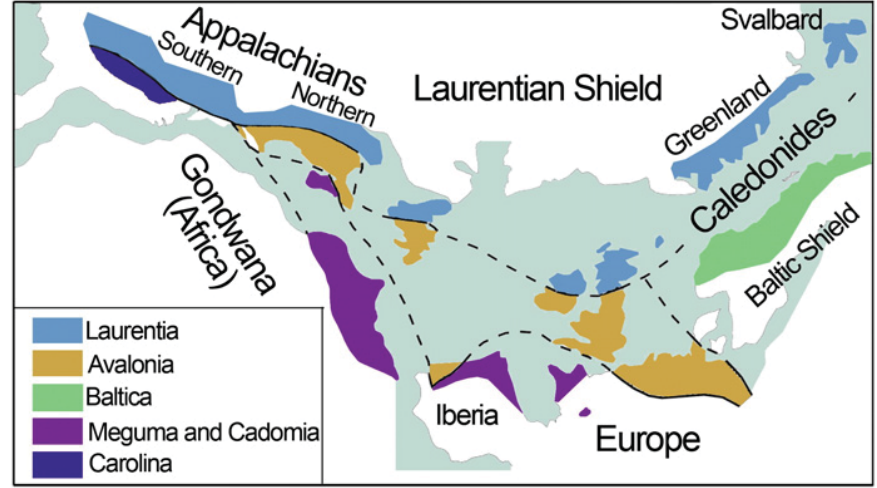

Fig. 14. The Appalachian-Caledonian belt, shown in a Pangea fit (after Cocks et al., 1997; McNamara et al., 2001).

Alps, various steep subduction segments and an asthenospheric upwelling beneath the Pannonian basin, below which some remnants of slabs are also observed (Dando et al., 2011).

Similar to the Carpathians, there is no clear seismic evidence for the presence (or the depth extent) of the crustal roots beneath the Dinarides, the Apennines, and the Caucasus although compressional tectonics and high topography suggest their presence. Beneath the Apennines the crust is apparently very thin $(30-35 \mathrm{~km})$, while beneath the Dinarides is can be $40-45 \mathrm{~km}$ thick. The deep crustal structure beneath the Caucasus is unknown due to the lack of seismic data, but the presence of the subducting slab with associated crustal root is suspected from a strong negative gravity anomaly.

\subsubsection{Cratonic crustal roots}

Several unusual crustal structures with well preserved crustal roots extending deeper than $50 \mathrm{~km}$ and locally reaching 55-60 km are documented in the cratonic parts of Europe (Figs. 16, 19a, c). While the presence of a deep crustal root at the Archean-Svecofennian suture in the Baltic Shield is well known (e.g. Korja and Heikkinen, 2005; Korja et al., 2009), it is not broadly acknowledged that similar crustal roots, down to a 55-60 km depth, are also present beneath some terranes of the Volga-Uralian sub-craton and the Ukrainian shield (e.g. Trofimov, 2006). The age of these crustal roots can be as old as Paleoproterozoic and their origin remains speculative
(Artemieva et al., 2006; Artemieva and Thybo, 2008). However, it is intriguing if such deep crustal roots extending down into the eclogite stability field can be preserved for more than a billion years. As discussed in Section 2.5.3, in the cold and dry cratonic lower crust metamorphic reactions can be very slow because of a critical dependence of the rate of gabbro/basalt-eclogite phase transition on temperature and fluid regime, but lack of experimental data leaves the question open, if gabbro can remain metastable for a billion years.

\subsubsection{Crustal roots in Paleozoic orogens: Uralides}

By analogy with modern zones of continent-continent collision, deep crustal roots extending down to more than $50 \mathrm{~km}$ should be expected to be formed in the Paleozoic orogens as well. In particular, the Urals orogen has preserved a thick crustal root until present (Fig. 20c). The Uralides orogeny took place in the Palaeozoic (at 450-250 Ma) and the orogen was formed by accretion of series of island arcs, volcanic complexes and fragments of microcontinents to the eastern edge of the East European craton during the collision of the European and the Kazakhstan plates starting in the Early Ordovician-Carboniferous time (Sengör et al., 1993; Zonenshain et al., 1990). Although much of the topographic elevation is lost (the modern topography of the Urals came into existence only during the Tertiary-Quaternary (Morozov, 2001)), the orogen has a pronounced, more than $50 \mathrm{~km}$ thick, mafic crustal root with very high average crustal velocities (Berzin et al., 1996; Juhlin et al., 1998), reaching down to $65 \mathrm{~km}$ in the Polar and in the Southern Urals (Carbonell et al., 1996; Druzhinin et al., 1990). The presence of the crustal root is considered as an evidence of missing postorogenic extension (Steer et al., 1998).

In the southern part of the orogen, along the URSEIS seismic profile, lower crustal velocities of more than $7.8 \mathrm{~km} / \mathrm{s}$ have been observed; they transform gradually to velocities of ca. $8.0 \mathrm{~km} / \mathrm{s}$ (Echtler et al., 1996) interpreted as evidence for eclogitic crustal root. The survival of the deep crustal root below the depth of gabbro/basalt-eclogite phase transition since Paleozoic (i.e. for several hundred million years) raises questions of its mechanical stability. Southern Urals, in the part where a deep crustal root is observed, is characterized by anomalously low surface heat flow (ca. $25 \mathrm{~mW} / \mathrm{m}^{2}$, Kukkonen et al., 1997). Although, various reasons for the heat flow anomaly have been proposed (e.g. paleoclimatic signal, low crustal heat production anomaly, groundwater circulation), one cannot rule out that a part of the anomaly has a deep origin and that the lower crustal temperature is very low, thus providing long-term mechanical stability of the crustal root. In particular, thermal models with a low crustal heat a)

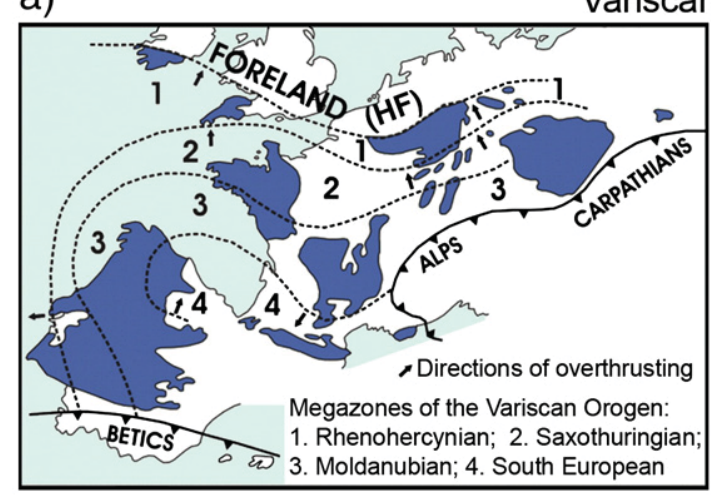

Variscan Massifs

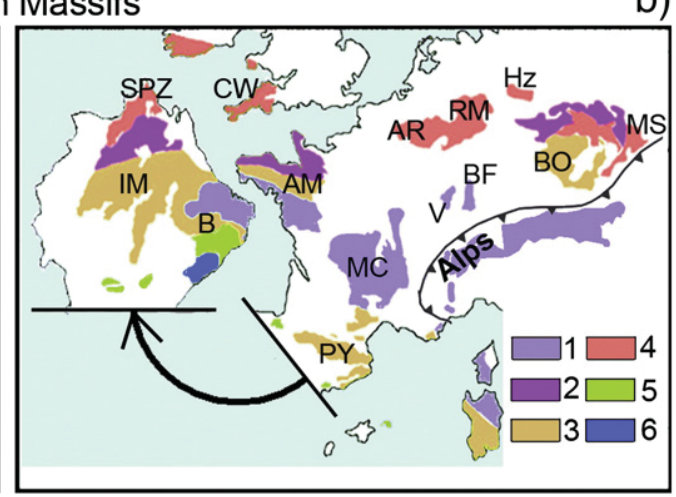

Fig. 15. (a) Variscan massifs (in blue) and megazones of the Variscan orogen (after Bromley and Holl, 1986). HF = Hercynian Front. (b) Map of Variscan massifs; massifs with similar geological features are shown by the same colors. The Iberian Peninsula is rotated to its Paleozoic position (modified after Martinez Catalan, 1990). 1-allochthonous terranes of various origins including the continental margin of Gondwana, non-Gondwana domains and oceanic crust; 2-6-allochthonous or parallochthonous domains of the Gondwana realm; 2-Saxothuringian zone; 3-Central Armorican and Central Iberian zone, the Pyrenees; 4-Moravo-Silesian and Rhenohercynian zones, SW England and Ireland, and the South Portuguese zone; 5-West-Asturian-Leonese zone; 6-Cantabrian zone. Abbreviations: AM = Armorican Massif; AR = Ardennes Massif; B = Brabant Massif; BF = Black Forest (Rhine Graben); BO = Bohemian Massif; CW = Cornwall; Hz = Harz Massif; IM = Iberian Massif; MC = Massif Central; MS = Moravo-Silesian Massif; PY = Pyrenees; RM = Rhenish Massif; SPZ = South Portuguese zone; $\mathrm{V}=$ Les Vosges (Rhine Graben). 


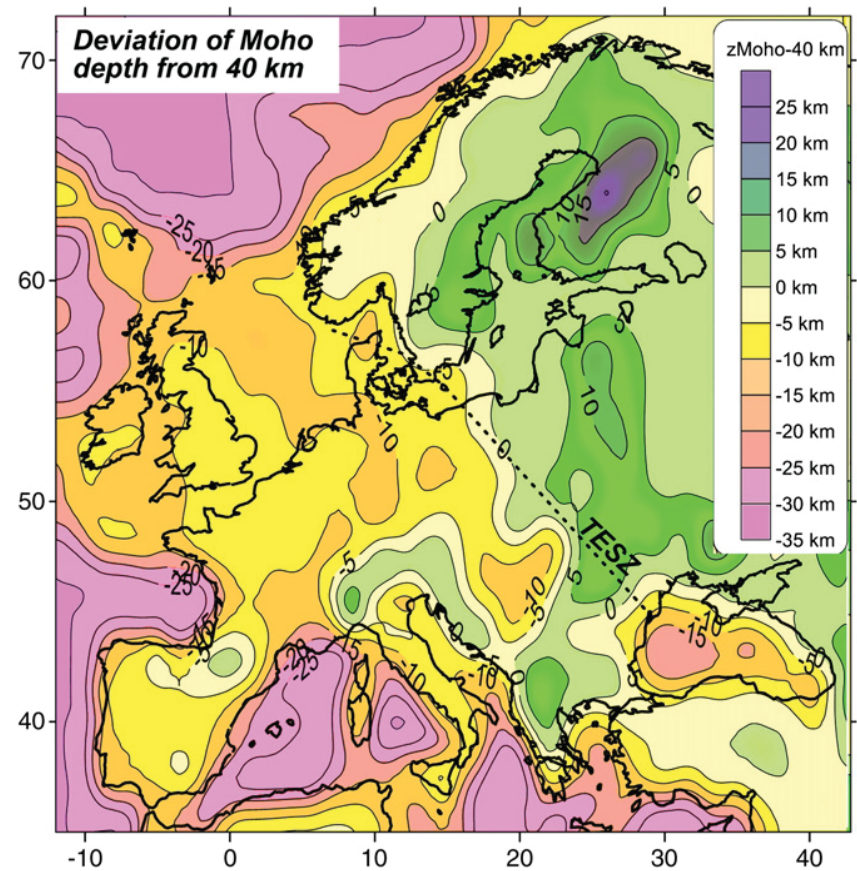

Fig. 16. Structure of the European crust shown as deviation of the Moho depth from $40 \mathrm{~km}$ depth. The map is based on a 5 deg $\times 5$ deg interpolation of all published seismic data smoothed with a low-pass filter. Data sources: Pavlenkova (1996), Ziegler and Dèzes (2006), Artemieva (2007), Kelly et al. (2007), Artemieva and Thybo (2012). Dashed line-the TESZ.

production in island arc complexes of the Uralian crust suggest Moho temperatures (at a depth of ca. $60 \mathrm{~km}$ ) of $550-600^{\circ} \mathrm{C}$ (Kukkonen et al., 1997). However, the presence of even trace amounts of water, which one can expect to be still present in paleo-subduction zones, would significantly accelerate the rate of gabbro/basalt-eclogite phase transition (Ahrens and Schubert, 1975; Austrheim et al., 1997).
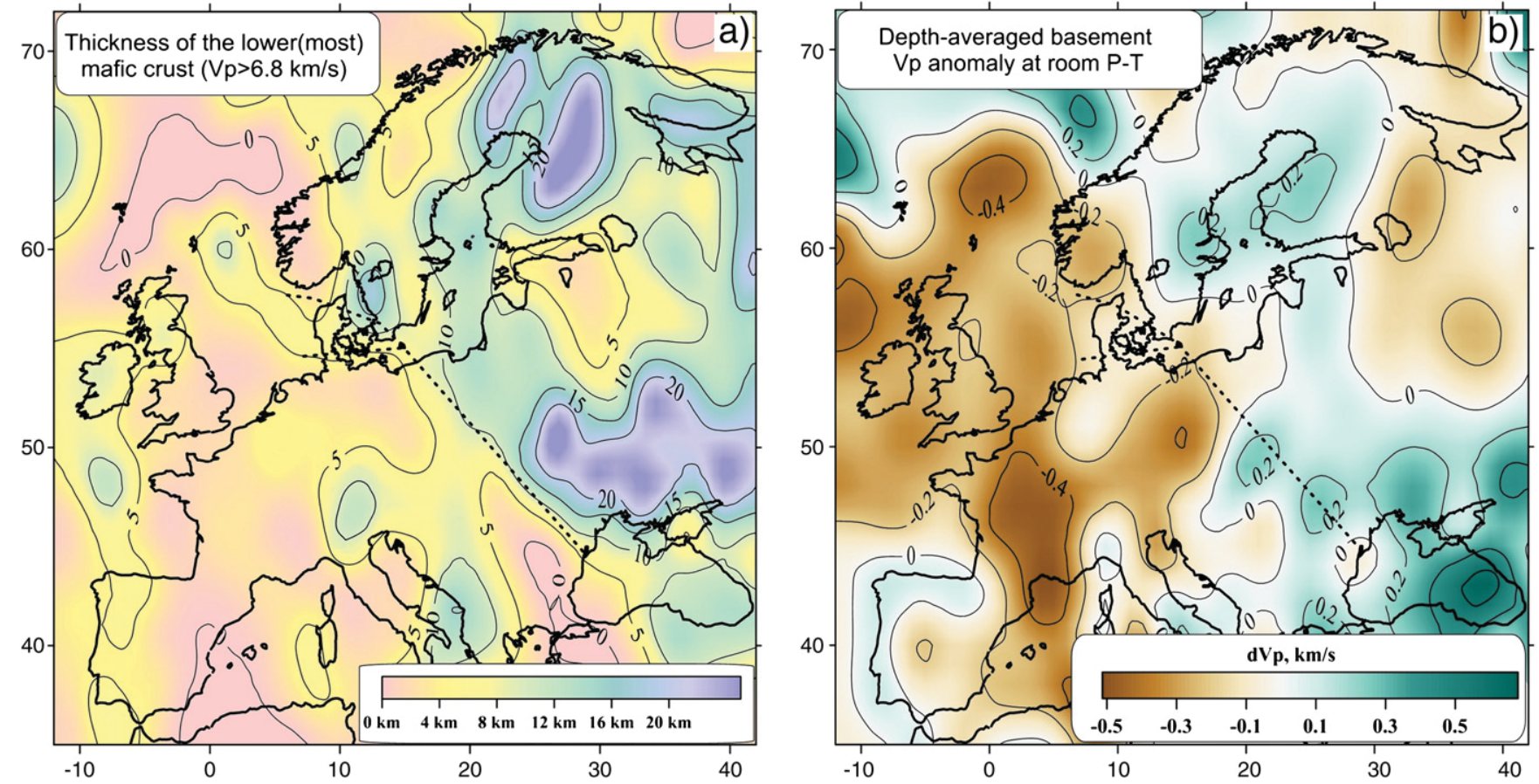

Fig. 17. Vp-velocity structure of the European crust. The map is based on a 5 deg $\times 5$ deg interpolation of all published seismic data; in case of multiple interpretations of the same data, more recent results were used. Data sources: Pavlenkova (1996), Ziegler and Dèzes (2006), Artemieva (2007), Kelly et al. (2007), Artemieva and Thybo (2012). Dashed linethe TESZ. (a) Thickness of the mafic lower crust (crustal layers with $\mathrm{Vp}>6.8 \mathrm{~km} / \mathrm{s}$ ); (b) variations in average Vp seismic velocities (recalculated to room P-T conditions) in the consolidated crust in Europe. Zero corresponds to average in situ $\mathrm{Vp}=6.6 \mathrm{~km} / \mathrm{s}$ in a region with a platform geotherm (surface heat flow $\sim 55 \mathrm{~mW} / \mathrm{m}^{2}$ ). The correction to lateral temperature variations is based on the regional thermal model (Artemieva, 2007) for $\partial \mathrm{Vp} / \partial \mathrm{T}=-0.39 \mathrm{e}-3 \mathrm{~m} / \mathrm{s} / \mathrm{K}$ (the value reported by Christensen and Mooney (1995) for granite and basalt). Dashed line-the TESZ. 

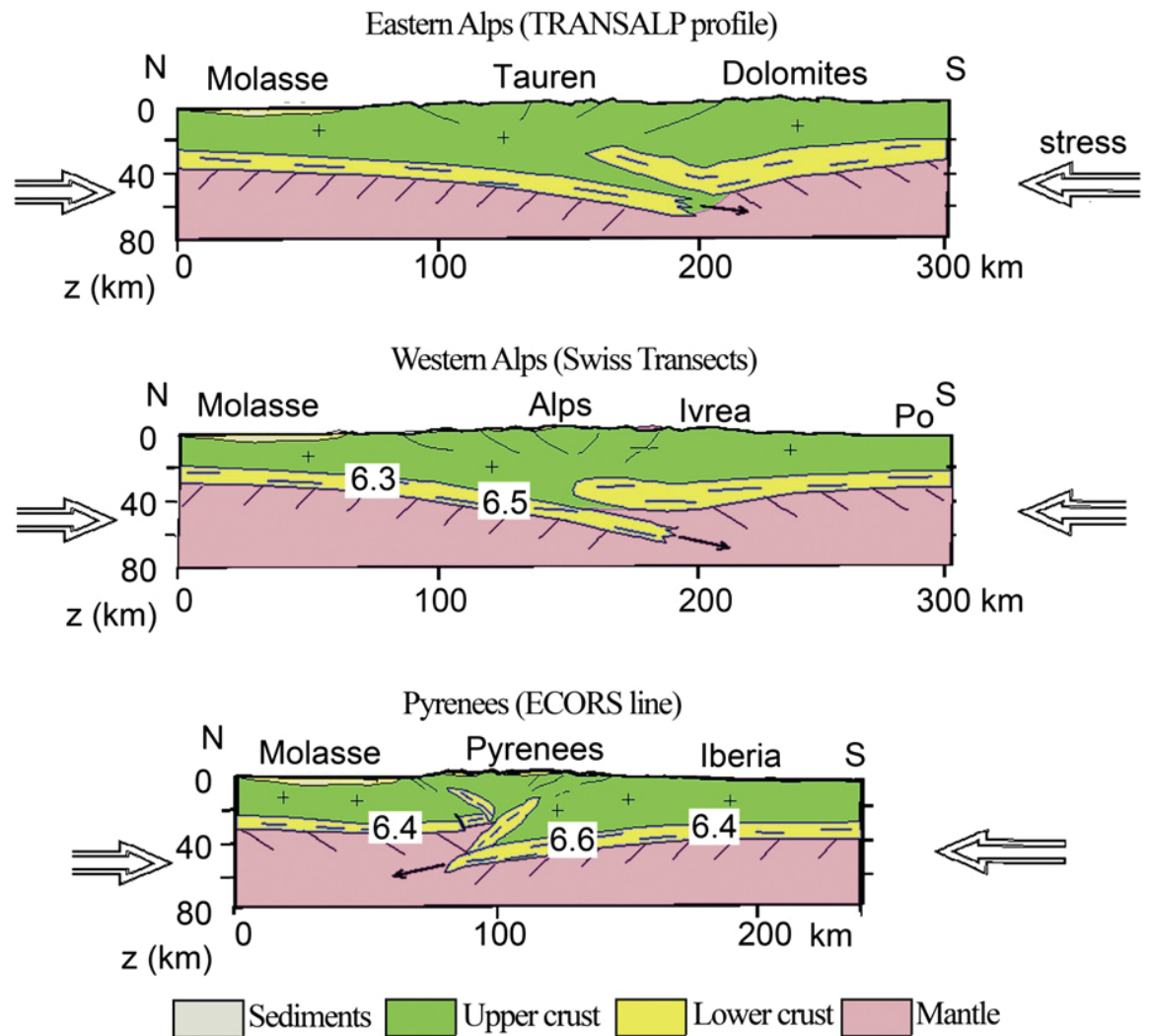

Fig. 18. Present subduction in the Alps and the Pyrenees (simplified from Choukroune, 1989; Gebrande et al., 2006; Pfiffner et al., 2001; Souriau and Pauchet, 1998; TRANSALP Working Group, 2002; Willingshofer and Cloetingh, 2003). Laminated lower crust (and lithospheric mantle) is partly broken, partly introduced into mantle. Profile locations are shown in Fig. 12.

\subsubsection{Missing crustal roots in Caledonides and Variscides}

Compared to most other Paleozoic mountains (the Caledonides, the main Appalachians, the Variscides), the Uralides are unique in preserving the crustal root (Fig. 20cd). Although, similar to other continent-continent collision zones, crustal roots should have been formed underneath the Caledonian and the Variscan mountain belts in the Paleozoic, at present they are absent in the Norwegian Caledonides, the Caledonides of Scotland and North America, and the Variscides (Clegg and England, 2003; Cook et al., 1988; Stratford et al., 2009) (Figs. 16, 19, 20). A local crustal root with intermediate velocities is still preserved only in the very south of the Appalachians (Hawman, 2008). However, in the Newfoundland Appalachians the crust is thin (Fig. 20d) and seismic data were interpreted as evidence for partial eclogitization (Chian et al., 1998). Since the Urals orogen was not easily accessible for geologic and geophysical studies to western researchers and international publications on its structure remained scarce until 1990-ies, it has long been believed that a thin crust such as in the Caledonides, Variscides, and the northern Appalachians (Behr and Heinrichs, 1987; Meissner, 1986; Nelson, 1992) is typical for all Paleozoic orogens.

3.2.4.1. European Caledonides. Today the crust in the Norwegian Caledonides shows no sign of the orogenic crustal root and gradually thickens eastwards towards the Baltic Shield from about $28 \mathrm{~km}$ at the coast of Norway (Ottemoeller and Michs, 2004) to ca. $40 \mathrm{~km}$ beneath the southern dome (Stratford et al., 2009). Similar crustal thickness, of about $36-40 \mathrm{~km}$, is typical for the northern Appalachians (Hughes and Luetgert, 1991) (Fig. 20d). In southern East Greenland, within the Caledonian deformation zone, crustal thickness calculated by receiver functions varies between 24 and $32 \mathrm{~km}$ (Dahl-Jensen et al., 2003; Kumar et al., 2007). Similar to the Newfoundland
Appalachians (Clowes et al., 2010), no crustal roots are known in the Irish and British Caledonides, where the crustal thickness is $30-35 \mathrm{~km}$ (see summary by Kelly et al., 2007) and reduces to less than $20 \mathrm{~km}$ at the Atlantic shelf area (Roberts et al., 2009).

The German-Polish Caledonides form a relatively narrow belt at the northern margin of the Variscan structure (Fig. 12). Toward the end of the Carboniferous, the northward Variscan compression initiated orthogonal extensional stresses and created numerous rifts and basins with magmatic intrusions in the vast area which extends from northern Germany and Denmark to the southern coasts of Norway and Sweden (Bayer et al., 1999; Marotta et al., 2001; Thybo, 1997; Ziegler and Cloetingh, 2004). The formation of these rifts and basins started long after the Caledonian orogeny had finished and the Variscan orogeny had started (Heermans et al., 2004). In the northern foreland of the Variscides the most prominent Paleozoic extensional structures are the Oslo Graben, the Skagerrak area, and the North German Basin. Huge amounts of mafic magmas have entered the stretched lower crust in all Paleozoic rifts and basins at the northern margins of the Caledonian-Variscan orogen, sometimes producing remarkable gravity highs as at the border between the Danish- and the North German Basins (Sandrin and Thybo, 2008). Seismic data from the northern edge of the former Caledonian orogeny in Denmark show high sub-Moho velocities interpreted as the presence of a possibly eclogitic material (Abramovitz et al., 1998).

In the North German Basin, quick subsidence began in the Latest Carboniferous-Earliest Permian, preceded by extensive faulting and magmatism, and followed by several tectonic events which led to formation of Meso-Cenozoic sub-basins (Heermans et al., 2004; Ziegler and Dèzes, 2006). Thickness of sediments in the North German Basin reaches $10 \mathrm{~km}$ and its sub-basins contain a thick (up to $9 \mathrm{~km}$ in thickness) layer of the Upper Permian (Zechstein) salt. Seismic 

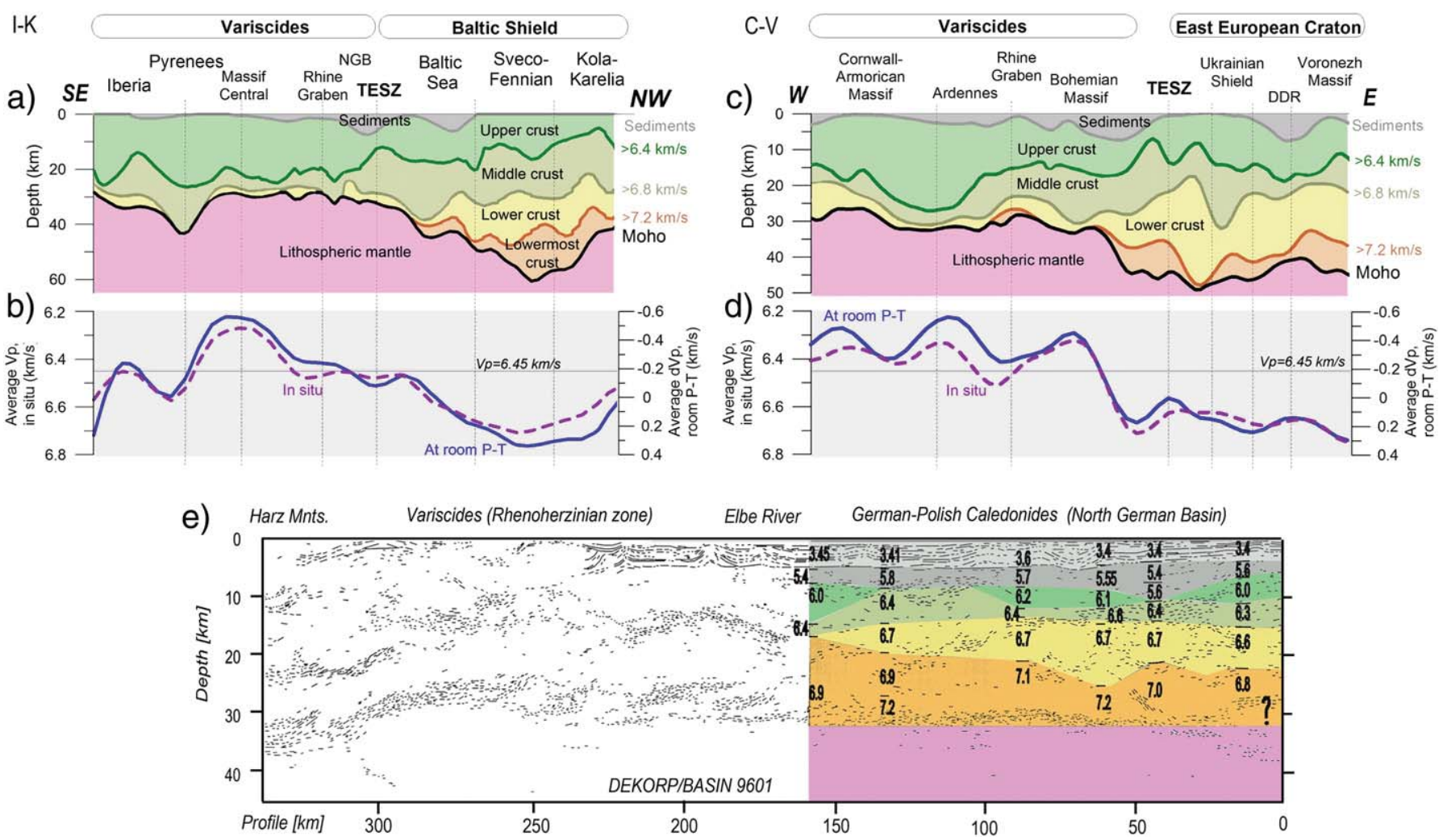

Fig. 19. (a-d) Two cross-sections through the European crust constrained by all available seismic data averaged within $600 \mathrm{~km}$-wide corridors along the profiles (the locations of the profiles are marked in Fig. 12). Upper plots (a, c) show the subdivision of the lithosphere into compositional layers as based on P-wave seismic velocities (Mengel et al., 1991; Wedepohl, 1995): granites and gneisses (upper crust) Vp<6.4-6.5 km/s; felsic granulites (middle crust) Vp 6.4-6.8 km/s; mafic granulites (lower crust) Vp 6.8-7.2 km/s; pyroxenites and eclogite (lowermost crust) 7.2-7.6 km/s; spinel lherzolites and harzburgites (lithospheric mantle) Vp $>7.8 \mathrm{~km} / \mathrm{s}$. For data sources see Pavlenkova (1996), Artemieva et al. (2006), Ziegler and Dèzes (2006), Artemieva (2007), Kelly et al. (2007), Artemieva and Thybo (2012). Lower plots (b, d) show variations in mean P-wave velocity in the basement of the European crust (i.e. the crust without the sediments) based on seismic data. Dashed lines refer to in situ conditions (as sampled by seismic methods) and reflect variations in both crustal composition and average crustal temperatures. Solid lines-Vp variations corrected for lateral temperature variations in the crust (based on Artemieva, 2003, 2006), which reflect variations in the average crustal composition and anisotropy (in case it is present). Zero corresponds to average in situ $\mathrm{Vp}=6.6 \mathrm{~km} / \mathrm{s}$ in a region with a platform geotherm (surface heat flow $\sim 55 \mathrm{~mW} / \mathrm{m}^{2}$ ). TESZ = Trans-European Suture Zone; DDR = Dnieper-Donets paleorift; NGB = North German basin. (e) P-wave seismic velocity structure of the European Variscides and Caledonides (North German Basin) along the profile DEKORP/BASIN 9601. Seismic velocities are derived from wide-angle seismic data and shown in relation to the line drawing of the seismic reflection data (based on Bayer et al., 1999). Profile location is shown in Fig. 12.

data indicate the presence of massive high-velocity mafic intrusions in the lower part of the crust and a flat and shallow (possibly new) Moho at a depth of $30-32 \mathrm{~km}$, as in the adjacent Variscan terranes (Bayer et al., 1995; Bilgili et al., 2007; Rabbel et al., 1995; Wilson et al., 2004) (Figs. 19, 20a).

3.2.4.2. Variscides. The crustal structure of the Variscan orogen is truly unusual.

(i) The crust in the Variscan terranes of Europe is surprisingly thin, ca. $28-32 \mathrm{~km}$ only (Figs. 16, 19ac, 20a). Only some of the Paleozoic massifs show slightly larger crustal thicknesses (up to $35 \mathrm{~km}$ ). In continental regions, similar crustal thickness is observed at present only in the recently extended regions, such as the Cenozoic Basin and Range province in western USA (Fig. 20b), where recent teleseismic receiver function studies indicate Moho depths variations from $29.5 \mathrm{~km}$ in the east to $36.5 \mathrm{~km}$ in the west; wide-angle refraction/reflection survey for the same region gives comparable Moho depths of 32-37 km (Gashawbeza et al., 2008). By comparison, the crust of the East European craton is typically ca. 15-20 km thicker (Fig. 16).

(ii) The Variscan crust has a rather uniform thickness with only small regional variations (Fig. 19a, c, e). An important characteristic of the present-day Variscan crust is lack of relationship between the crustal structure and pre-existing terrane boundaries. The Moho is sharp and subhorizontal over the entire western Europe, even where it crosses the major sutures of the Variscan orogen (Figs. 16, 19e).

(iii) The Variscan terranes have a significantly reduced thickness of the mafic crust, which commonly is $3-5 \mathrm{~km}$ thick as compared to $10-25 \mathrm{~km}$ thick mafic layer of the cratonic crust (Figs. 17a, 19). As a consequence, low average basement velocities are typical of the Variscan crust (Fig. 17b and Section 3.3).

(iv) A characteristic feature of the Variscan orogen is a widespread reflectivity in the lower crust (Fig. 19e and Section 4.1).

Such a crustal structure, with a thin crust, generally with a seismically laminated lower crust and a sharp subhorizontal Moho which ignores the pre-existing tectonic elements, is often interpreted as an indication that a large part of the lower crust, and probably of the lithospheric mantle, has been delaminated after the main compressional events took place in the Paleozoic orogenies. These processes are discussed in detail later.

The Trans-European Suture Zones (TESZ), one of the most important tectonic boundaries in Europe which separates the Variscan terranes and the German-Polish Caledonides from the Precambrian, mainly Archean-Paleoproterozoic in age, East-European craton (Fig. 11), marks a sharp change in the crustal structure from a thin and rather uniform crust of western and central Europe to a 45-50 km thick cratonic crust with the "classical" three-layered structure, including a highvelocity (mafic) lower crust (EUROBRIDGE SWG, 1999; Korja and 

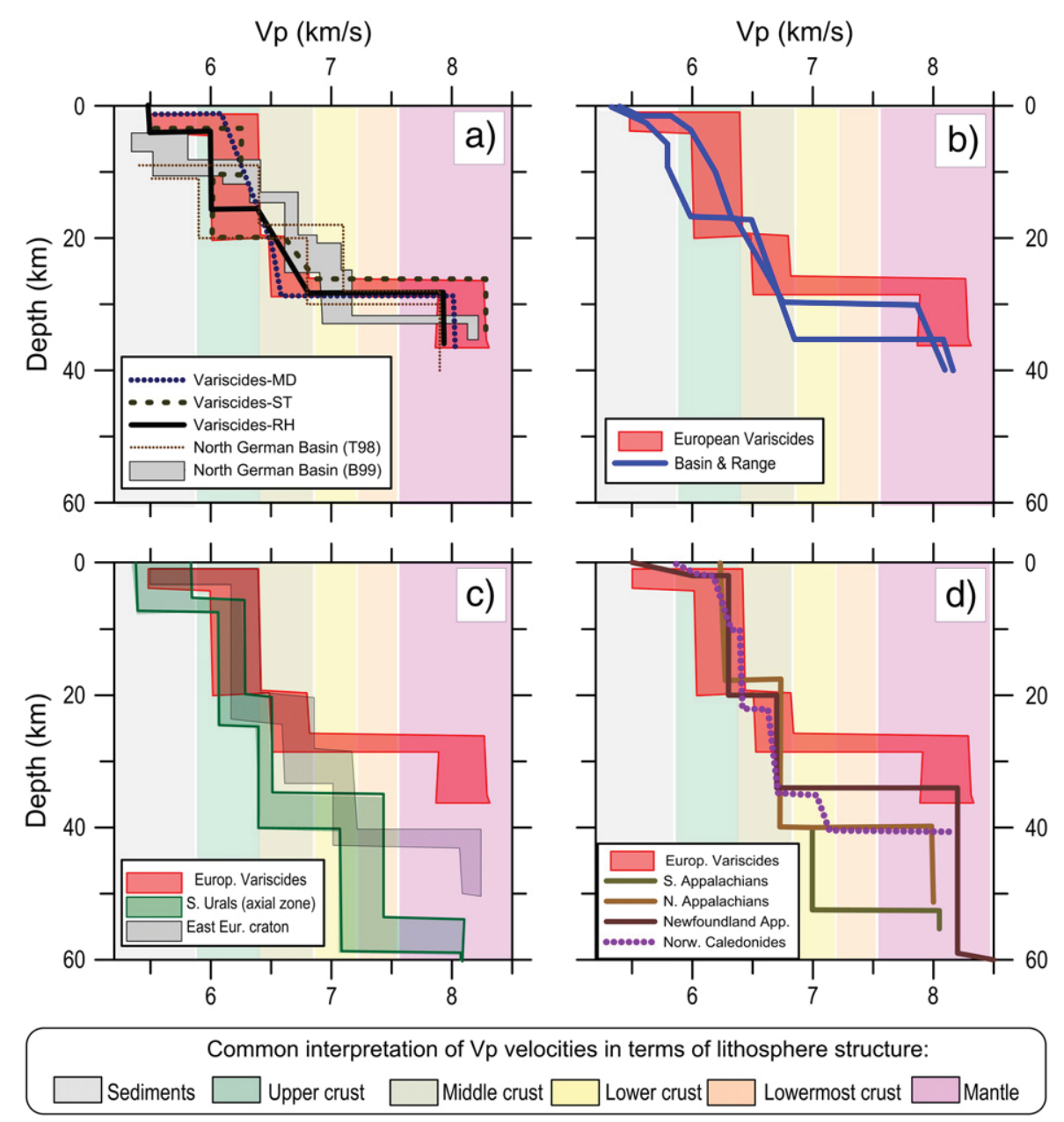

Fig. 20. Profiles of a typical 1-D P-wave velocity structure with depth extracted from seismic velocity models for the continental crust of Paleozoic Europe and North America: (a) for three Variscan sub-terranes of western Europe (RH = Rhenohercynian zone, ST = Saxothuringian zone, and MD = Moldanubian zone) (Blundell et al., 1992) and different parts of the North German Basin (Bayer et al., 1999; DEKORP-BASIN RG et al., 1999; Tryggvason et al., 1998); (c) for Southern Urals (the axial zone, Carbonell et al., 1996; Morozov, 2001); (d) for Caledonides of Southern Norway (Stratford et al., 2009); northern and southern Appalachians (Taylor, 1989b), and Newfoundland Appalachians (Clowes et al., 2010). Velocity-depth profiles for extensional crust of the Basin and Range Province (western USA, Lerch et al., 2007) and typical crust of the East European cratons are shown for a comparison (b-c). The velocity-depth range typical for the Variscan Europe is shown in (b-d) by red shading.

Heikkinen, 2005; Pavlenkova, 1996 and many others) (Figs. 19c, 20c). However, in intracratonic zones of paleoextension (Riphean to Devonian paleorifts within the craton interior) the crustal structure resembles the Variscan-Caledonian crust (Fig. 17a): Moho depth reduces to $35-40 \mathrm{~km}$ and becomes dominated by a thick $(>20 \mathrm{~km})$ upper crust, with the middle crust being almost absent and the lower crust significantly thinned (Artemieva, 2007; Kostyuchenko et al., 1999).

\subsubsection{Meso-Cenozoic rifts}

One of the most prominent Mesozoic rifts of Europe is the rift system of the North Sea, which includes the Viking Graben in the north and the Central Graben in the south. Both of them are deeply buried under thick Tertiary sediments. The formation of the North Sea rifts has probably begun at the late stages of the Caledonian orogeny, but the major phase was connected to Mesozoic rifting at the Atlantic passive continental margin (Ziegler, 1992). Mesozoic rifting, which began in Triassic-early Jurassic, continued for an unusually long time of ca. $175 \mathrm{Ma}$. The subsequent post-rift thermal subsidence, partly associated with delayed thermal reactions due to late metamorphic reactions in the uppermost mantle, occurred during the Tertiary (Vejbaek, 1990; Ziegler, 1992). A vast amount of data on the crustal structure of the North Sea (see e.g. summaries by Klemperer and Hobbs, 1991; Ziegler and Dèzes, 2006) indicates crustal thickness of ca. 25-30 km, which reduces to $24-26 \mathrm{~km}$ along the Viking Graben (central North Sea).
Alike European Caledonides, a large part of the Variscides has been reworked by Meso-Cenozoic events as a result of large relative movements of the Eurasian and African plates and tectono-magmatic activity in the Central European Rift System. The cause of Cenozoic volcanism in the latter (which includes the Rhinegraben, western Rhenish Massif and Massif (entral) is still much debated. The proposed mechanisms include plume-related active rifting, passive rifting in response to collisional processes in the Alps and Pyrenees, back-arc rifting, or slab pull associated with Alpine subduction. Similar to the rift system of the North Sea, the crust in the Central European Rift System is thin, 24 to 30 km (e.g. Ziegler and Dèzes, 2006) (Fig. 16).

\subsection{Seismic evidence for lower crustal delamination in the Variscides}

\subsubsection{Mean crustal velocity in western Europe}

Seismic velocity structure of the crust in continental Europe is highly heterogeneous due to variations in crustal structure, composition and in thermal state of the crust (Fig. 17); additionally some part of crustal velocity variations can be caused by anisotropy. The crust of the East European craton with mean basement velocities typically between 6.4 and $6.6 \mathrm{~km} / \mathrm{s}$ (Figs. 19c, 20c) provides a convenient regional reference frame for examining the anomalous structure of the crust of western Europe, since mean basement velocities of ca. $6.5 \mathrm{~km} / \mathrm{s}$ are statistically representative of stable continental crust (Christensen and Mooney, 1995). [By crustal basement we mean the consolidated 
crust, i.e. the crust without the sedimentary layer]. The discussion of the details of the velocity structure of the East European craton is outside the scope of the present review and can be found in Artemieva (2007).

The transition from the stable cratonic crust to Variscan and Caledonian crust of western Europe is marked by a sharp and pronounced contrast in mean basement velocity constrained by various seismic surveys (Fig. 19d). New seismic data from the Norwegian Caledonides indicate mean basement velocity of ca. $6.5-6.6 \mathrm{~km} / \mathrm{s}$ beneath most of the Norwegian mountains (Stratford et al., 2009). However, in their southern, most uplifted part, mean velocity is low $(6.3-6.4 \mathrm{~km} / \mathrm{s}$ ) suggesting that a large part of the lower crust, and probably of the lithospheric mantle, has been delaminated during or after the Paleozoic orogeny (Figs. 17ab, 20d). Recent and still on-going uplift of the southern Norwegian dome (Anell et al., 2009; Japsen and Chalmers, 2000) provides an indirect evidence for the timing (Neogene, and perhaps even Plio-Pleistocene) when the crustal root of the Norwegian Caledonides may have been lost.

Similar to the southern part of the Norwegian Caledonides, mean basement crustal velocity in the Irish and British Caledonides is 6.2-6.4 km/s (Kelly et al., 2007). Alike European Caledonides (no seismic data exist so far for the Caledonides of Greenland), low mean basement velocities (6.2-6.4 km/s) are typical for the Variscan crust of Europe. The Central European rift system which extends from Massif Central to the Central Graben of the North Sea has extremely low mean basement velocities $(<6.3 \mathrm{~km} / \mathrm{s})$ (Fig. 17b).

Due to highly variable crustal geotherms (owing to variations in crustal heat production, geodynamic regime, heat flow from the mantle, the presence of recent magmatism, Fig. 5), the contribution of temperature variations into seismic velocity variations recorded in seismic surveys can be significant. Average crustal temperatures in the continental crust of Europe may differ by up to $200{ }^{\circ} \mathrm{C}$ (Artemieva, 2007); note that the variation could have been much larger if it were not for a generally inverse correlation between the thermal regime of the crust and crustal thickness in Europe. When the effect of temperature variations is removed, mean P-wave velocities in the basement reflect primarily structural and compositional variations in the crust (Figs. 17b, 19b, d). For example, in the Pannonian Basin in situ seismic velocities in the crustal basement are similar to the Variscides; however, temperature-corrected Vp seismic velocity is ca. $0.2 \mathrm{~km} / \mathrm{s}$ higher than typical velocities in the Variscan basement, suggesting that Cenozoic magmatism controls the present-day velocity and density structure of the Pannonian crust.

The general patterns of the mean basement velocity variations are similar at in situ and at temperature-adjusted conditions, but the amplitudes of the anomalies are stronger in the latter case. As with in situ velocities, the effect of crustal anisotropy can also be present. However, we omit the latter from the discussion due to insufficient seismic data for many tectonic provinces of western Europe. Several regions can be mentioned due to distinct anomalies in crustal velocity structure. The mean velocity structure of the Variscides is apparently relatively homogeneous with a ca. $-0.4 \mathrm{~km} / \mathrm{s} \mathrm{Vp}$ anomaly as compared to the stable platform; similar low velocities are typical of the British-Irish Caledonides and southern Norway (Fig. 17b). The lowest mean basement velocities are determined for the Massif Central and the Atlantic shelf area. In contrast, very high mean velocities (with a $+0.3 \mathrm{~km} / \mathrm{s} \mathrm{Vp}$ anomaly) in the basement of the Voring Plateau at the Norwegian shelf can be associated with mafic intrusions in the lower crust (compare with Fig. 17a).

\subsubsection{Thickness of crustal layers}

Structure of the crust, represented by thicknesses of individual crustal layers, provides further insights into tectonic evolution of western Europe and explanations for mean basement velocity variations (Figs. 17, 19). There is a remarkable correlation between the thicknesses of the upper and lower crust and the mean basement velocity. In Paleozoic Europe, a belt of the thickest upper crust (20 km and more) extends from the Irish-British Caledonides through the Armorican Massif to Iberia; the lower crust in these regions is nearly absent (Fig. 17a). In contrast, the crust of the Norwegian Caledonides has a significant thickness of the middle-crustal layer, which explains its higher mean basement velocity than in the Variscan Europe. However, the lower crust is apparently absent beneath the southern Norwegian mountains as well (Stratford et al., 2009).

There is a striking difference between the stable platform crust of the East European craton and the Caledonian-Variscan crust of Europe, in particular in thicknesses of the middle and the lower crustal layers (Figs. 17a, 19ac): while on the platform the middle crust is more than $10 \mathrm{~km}$ in thickness and the lower crust is typically 8 to $12 \mathrm{~km}$ thick (with significant regional variations), in the CaledonianVariscan structures the middle crust is much thinner $(4-8 \mathrm{~km})$ and the lower crustal layer is largely absent or only few kilometers thick.

Lower crustal xenoliths from different Variscan locations in Germany indicate that the deep crust is much more felsic (anorthosites, felsic granulites, metagranitoids, high-grade metasediments) than expected in continental settings and mafic granulites, which are commonly believed to be the major component of the lower crust, make only a few kilometers thick layer above the Moho (Fig. 21). This observation provides additional evidence for post-Variscan delamination of the lower crust in the Paleozoic parts of Europe (Abramovitz et al., 1998; Aichroth et al., 1992).

\subsection{Structure of the Variscan lithospheric mantle}

\subsubsection{Delaminated lithosphere}

Despite the complicated tectonic evolution of the Variscides, their lithospheric structure is surprisingly simple and homogeneous, providing a strong argument that orogenic lithospheric structures did not survive since Paleozoic (Artemieva et al., 2006). As discussed in Sections 3.2-3.3, the sharp, subhorizontal Moho of the Variscides crosses pre-existing terrane boundaries (Franke, 2006; Meissner et al., 1986), indicating that these Paleozoic mountain belthas lost its former high-velocity lower crustal roots. It is difficult to imagine a geodynamic process which would remove only the lower crust without affecting the lithospheric mantle formed during the Paleozoic orogeny.

In support of lithosphere delamination scenario, seismic data indicate a rather uniform seismic velocity structure of the Variscan lithospheric mantle. Furthermore, dominating subhorizontal wide-angle reflectors are imaged in the upper $90 \mathrm{~km}$ of the Variscan lithosphere (Faber and Bamford, 1979; ILIHA DSS Group, 1993), although the resolution on these studies is relatively low (due to the $>3 \mathrm{~km}$ intervals between the seismic stations along the refraction profiles). These observations are interpreted as indicating that the Hercynian structures have not been preserved in the European lithospheric mantle and that the Paleozoic lithospheric mantle of the Variscides or its significant part has been lost.

An example of on-going lithosphere delamination is provided by seismic data from the Vrancea Zone in the eastern Carpathians. A prominent deep, near-vertical lithospheric slab with high seismic velocities down to a $300 \mathrm{~km}$ depth and with a strong mantle seismicity underlies the eastern Carpathians at the sharpest bend of the mountain belt (Koulakov et al., 2010). Whether the slab is oceanic or continental, and whether this high-velocity cylindrical anomaly represents a subducting slab or a delaminated lithosphere is hotly debated (Fillerup et al., 2010; Lorinczi and Houseman, 2009; Martin et al., 2006; Tondi et al., 2009).

\subsubsection{Is the Variscan lithospheric mantle partly preserved?}

Seismic data on Pn anisotropy and SKS shear wave splitting indicate that the Variscan lithospheric mantle is strongly anisotropic. Seismic anisotropy of 6.5 to $15 \%$ for $P$-wave velocities has been interpreted 


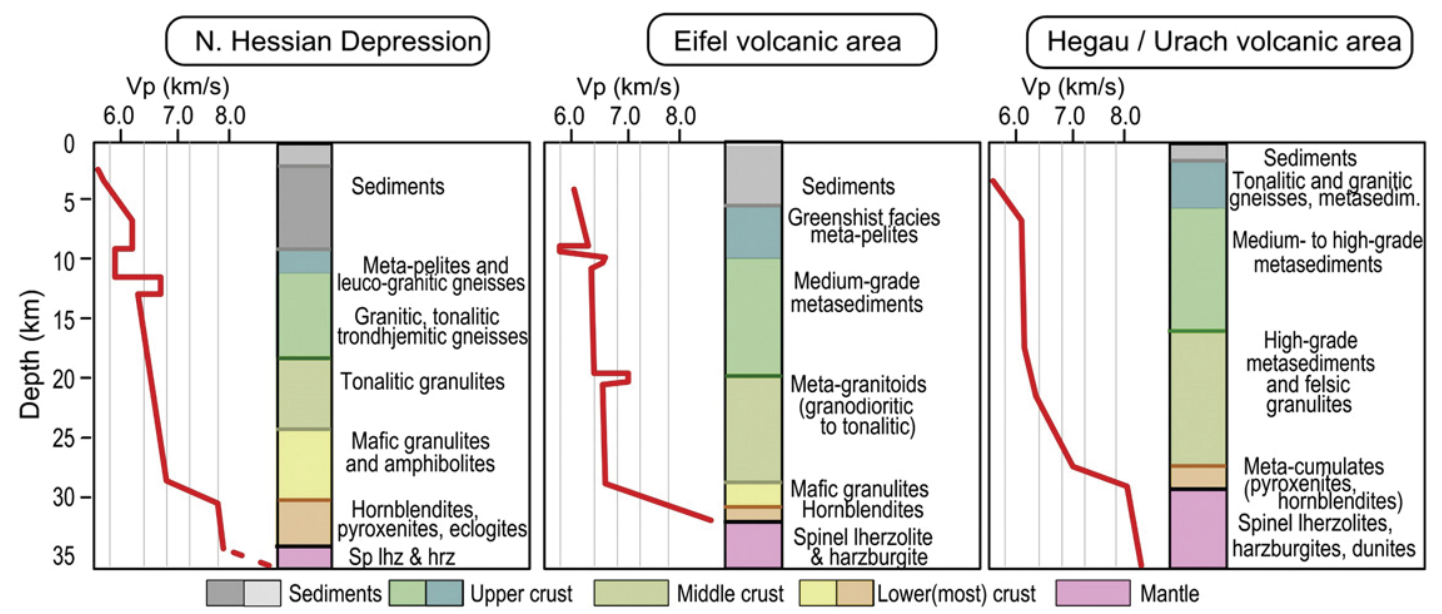

Fig. 21. Model profiles of crustal composition in three regions in Germany constrained by Vp seismic velocities (red lines) and crustal xenoliths (based on Downes, 1993; Mengel et al., 1991).

as evidence for paleosubduction zones associated with the closure of the oceanic domains and the consequent Hercynian orogeny (Plomerova et al., 1998). By the pattern of seismic anisotropy in the lithospheric mantle, the Variscides can be subdivided into two domains with NW- and SE-dipping anisotropic structures. The boundary between the two domains has a general SW-NE orientation and approximately corresponds to the suture between the Saxothuringian and Moldanubian terranes; the suture also corresponds to a ca. $40 \mathrm{~km}$ difference in lithospheric thickness and to a different depth of the electrical conductor in the mantle (Plomerova et al., 1998; Praus et al., 1990). NW- and SE-dipping anisotropic structures in the lithospheric mantle are interpreted as traces of two divergent systems of Paleozoic subduction zones with olivine orientations inherited from subducted ancient lithosphere (Babuška and Plomerová, 1992).

Studies of spinel lherzolite xenoliths from the Bohemian Massif (which sample the Variscan lithosphere down to a depth of ca. $70 \mathrm{~km}$ ) show that the Variscan lithospheric mantle (at least, in some locations) has a layered structure: the upper layer has a horizontal foliation whereas the lithospheric mantle below ca. $45 \mathrm{~km}$ depth has a vertical (or steeply dipping) layering (Christensen et al., 2001). A horizontal $a$-axis of mantle olivine in the lower lithospheric layer (between depths of 45 and $70 \mathrm{~km}$ ), with an approximately E-W strike, parallel to the observed fast shear wave direction, could have been inherited from the Variscan convergence.

Even more complicated patterns are observed in the upper mantle structure of the Armorican massif (north-western France) which has two distinct patterns of S-wave seismic anisotropy (Judenherc et al., 2002). The upper mantle at a $90-150 \mathrm{~km}$ depth has $+3 \%$ P-wave velocity anomaly in the southern domain and $-3 \%$ P-wave velocity anomaly in the northern domain. Furthermore, while the southern domain has a NW-SE orientation of $P n$ and SKS fast directions, which are parallel to the strike of the South Armorican shear zone and interpreted as orogen-related, SKS fast directions in the northern domain are not parallel to the strike of major Hercynian shear zones. This pattern of seismic anisotropy is interpreted to be formed during a pre-Hercynian subduction, when two parts of the Armorican massif were merged. Thus, in contrast to expectations, some parts of the Variscan and even pre-Variscan lithospheric mantle apparently are still preserved in the western Europe, at least within some of the Variscan massifs.

\section{Seismic reflections in the lithosphere of Western Europe}

Structural and compositional heterogeneities in the lithosphere produced by the processes of crust-mantle interaction are best detected by seismic reflection surveys (e.g. Meissner et al., 1991).
Especially strong reflections, caused by high impedance contrasts, occur from the Moho, from mafic/ultramafic sill-like intrusions in the sialic or intermediate lower crust (the seismic lamellae) (Meissner, 1986; Warner et al., 1996), and from fluid-solid interfaces (Stratford and Stern, 2004). Fluid-saturated shear zones in the lower crust that has experienced high-pressure metamorphism (eclogitization) may also have high reflection coefficients (Fountain et al., 1994). We next discuss seismic reflection observations in the crust and lithospheric mantle of western Europe and their geodynamic significance and relation to crust-mantle interaction processes.

\subsection{Reflections from the lower crust}

\subsubsection{Observations}

A characteristic feature of the crust in most areas of west-central Europe is the strongly reflective (laminated) lower crust, which has been documented by seismic reflection surveys in many countries (Figs. 19e, 22a). Dense reflections (lamellae) are widespread from the Faroe Islands in the north to the Alps and the Iberian Peninsula in the south, and from the continental boundary of the Mid-Atlantic ridge in the west to the TESZ in the east. They were intensively studied around Britain (by numerous BIRPS surveys), in Germany (DEKORP project), France (ECORS project), Iberia (IAM and ESCI projects), and Switzerland (see summaries by Meissner, 1986; Meissner and Kern, 2008; Meissner and Rabbel, 1999; Mooney and Meissner, 1992; Ziegler and Cloetingh, 2004). The only part of Phanerozoic Europe which is free from lower-crust reflectivity includes the terranes of East Avalonia in the North Sea (MONA LISA WG et al., 1997; Tanner and Meissner, 1996).

Worldwide, the most remarkable seismic lamellae are observed in extensional continental areas with thin crust and low mean basement velocities (Fig. 23), such as the Basin and Range Province in western USA (Prussen, 1991) and at passive margins. Some reflectivity is observed in young collisional orogens such as Central Tibet and the Alps (Ross et al., 2004) and in some parts of the Precambrian shields (e.g. Baltic and Canadian Shields) that have undergone Proterozoic orogenies, extension, and basin formation (BABEL WG, 1993; Kukkonen and Lahtinen, 2006; Prussen, 1991; Wu and Mereu, 1991), and not all of lower crustal reflectivity is associated with extension.

In contrast to west-central Europe, no significant lower crustal reflectivity has been observed in the thick and mafic lower crust of the East European craton, except for the Paleozoic Dnieper-Donbas rift (Maystrenko et al., 2003). In rifts and basins, strong extension and massif voluminous intrusions may create a "reflection-unfriendly" situation within the regional "reflection-friendly" lower crust, where a wide-spread, but moderate extension initiated mafic sills. An example 
a)

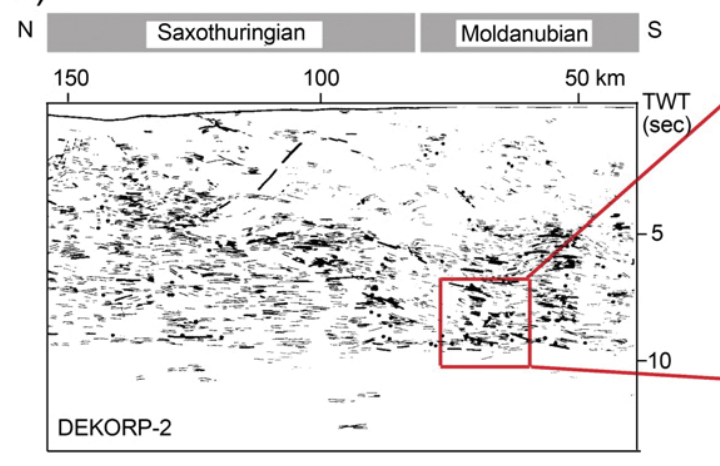

b)

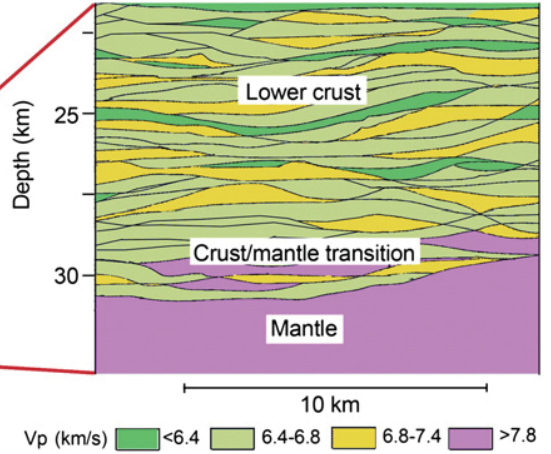

Fig. 22. Examples of seismic lamellae in the Variscan crust. (a) Line drawing of reflections from the migrated profile of DEKORP-2S. Thick lines-high quality reflections; vertical exaggeration 1.5 (after Behr and Heinrichs, 1987). (b) Sketch illustrating a possible interpretation of crustal reflectivity by high- and low-velocity lamellae in the lower crust (after Mooney and Meissner, 1992). Physical origin of seismic lamellae can be due to lithologic (mafic intrusions) and metamorphic layering.

of a "reflection-unfriendly" situation caused by massive magmatic intrusions is an African caldera where no reflections are observed within the volcanic complex, but many are observed outside it (Bauer et al., 2003). In contrast, "reflection-friendly" patterns are observed in some of the European rifts. For example, clear lamellae are observed in the lower crust of the Viking Graben but no reflections are seen in the crust of the surrounding regions (McBride et al., 2004); the thinned parts of the North Sea crust are strongly reflective within otherwise non-reflective crust (Thybo et al., 1998). It is interesting that some thin lamellae, possibly produced by ultramafic/piclogitic intrusions, are seen at the bottom of the mafic high-velocity $(\sim 7.2 \mathrm{~km} / \mathrm{s})$ lower crust in the North German Basin (Bayer et al., 1995, 1999) and in the Dnieper-Donets rift (Maystrenko et al., 2003).

Seismic lamellae are nearly always restricted to the continental lower crust. Only two examples of strong seismic reflectivity outside the lower crust are known at present. One of them (a "sill-like structure" which is $3-5 \mathrm{~km}$ thick and $175 \mathrm{~km}$ long) is located in the middle crust of the Variscan southern Spain (Simancas et al., 2003). The other structure (with numerous high-velocity sills) is observed in the upper crust of the south-western Baltic Shield down to a $15 \mathrm{~km}$ depth (Juhojuntti et al., 2001). By analogy with other (more isolated) upper crustal sills, this anomalous reflectivity structure, that crosses the Caledonian Deformation Front and the Precambrian TransScandinavian Igneous Belt, is interpreted to result from a Paleozoic extensional episode (Ferré et al., 2002).

\subsubsection{Interpretations}

The preferred subhorizontal layering of the intruding magmas in the low viscosity lower crust is caused by the development of extensional stresses (Mooney and Meissner, 1992; Petford et al., 2000). Moderate and long-time extension favors emplacement of multiple sills which create high impedance contrasts with the surrounding (mostly sialic) host rocks and produce the "lamellae". Clearly, as evidenced by crustal reflectivity, the widespread ascend and intrusion of mantle magmas into the lower crust is one of the important processes of an upward transport of mantle material into the crust. Melt sills associated with high crustal reflectivity are also observed in oceanic crusts on top of the Moho around rift axes and are reported for some prominent ophiolites (Canales et al., 2009; Korenaga and Kelemen, 1997; Singh et al., 2006; Zagorevski et al., 2006).

Observations of seismic reflectivity underline the key role of extension and the volume of intruded mafic magmas in producing crustal a)

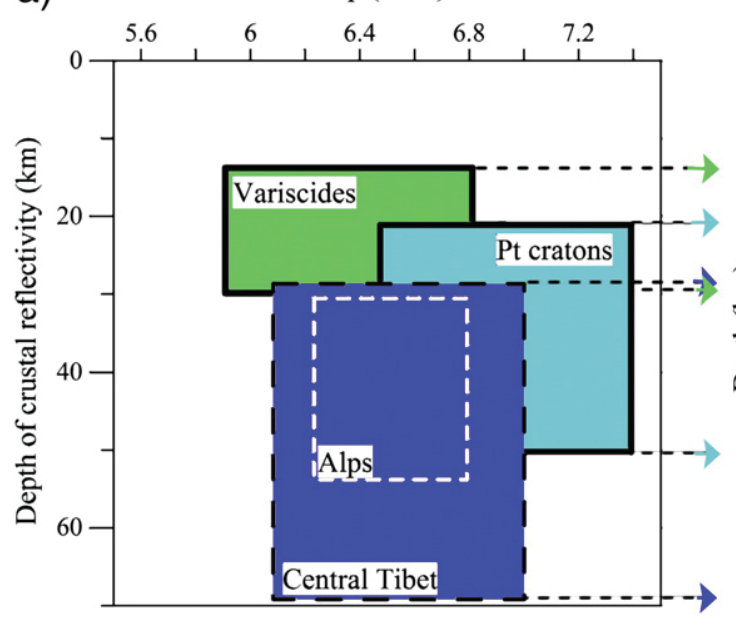

b) Temperature $\left({ }^{\circ} \mathrm{C}\right)$

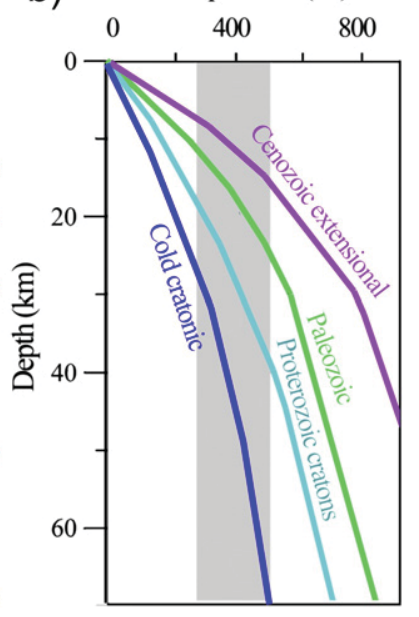

Fig. 23. (a) Seismic lamellae in the lower crust in various tectonic provinces where normal-incidence and wide-angle observations are available (based on compilation of Meissner et al., 2006). Four boxes refer to different tectonic settings: "Variscides" include both the Variscan European crust and Cenozoic crust of the Basin and Range province (USA); both tectonic provinces have undergone significant lithosphere extension; "Pt cratons" include seismic data from the Paleo-Mesoproterozoic structures of the Canadian and Baltic Shields; "Central Tibet" (only some selected measurements) and "Alps" are based on seismic data for two Cenozoic collisional structures. (b) Typical temperatures in the lithosphere of different continental tectonic structures (based on Artemieva and Mooney, 2001). Colors match the corresponding structures in plot (a). Cold lithospheric temperatures in the Tibet and the Alps are associated with subducting lithospheric slabs. Gray shading approximately marks the depths where seismic reflectivity is observed. As the plot illustrates, seismic reflectivity is commonly restricted to a depth with temperatures between 300 and $500{ }^{\circ} \mathrm{C}$. 
reflectivity. In case large-volume massive intrusions are emplaced during continental extension, they will form a totally new lower crust with no impedance contrast between the former host rock and the intruded magmas. Only when the volume of mafic-ultramafic intrusions (and the lithosphere extension) is moderate, can an alternation between the (low-velocity) host rock and the intruded layers develop (Fig. 22b).

Strong impedance contrasts and dominating horizontal layering of seismic lamellae have a striking similarity with reflectivity patterns produced by intruded mafic sills. Commonly, the thickness of an individual sill-layer in the lower crust is estimated to be $10 \mathrm{~m}$ to $100 \mathrm{~m}$ (Handy and Brun, 2004; Holliger and Levander, 1994; Meissner and Kern, 2008; Mooney and Meissner, 1992). Seismic studies in Canada allowed to recognize different scaling laws for sills, laccoliths and plutons, with sizes ranging from several $\mathrm{cm}$ to $600 \mathrm{~m}$ (Cruden and McCaffrey, 2001). These values are of the same order of magnitude as the estimates of sill size in the European crust based on seismic reflectivity (lamellae). A comparison of seismic data to synthetic data generated from a synthetic stochastic velocity model allows for estimates of geometry and seismic velocity contrast within high- and low-velocity lamellae in the lower crust. In particular, the Variscan crust can be modeled by a $400 \pm 300 \mathrm{~m}$ thick layers with a random velocity contrast of \pm 0.05 to $\pm 0.50 \mathrm{~km} / \mathrm{s}$ with respect to mean crustal velocity (e.g. Wenzel et al., 1987). A similar study based on the PASSCAL Basin and Range experiment (Holbrook, 1990) explains seismic data by a $300 \mathrm{~m}$ thick and ca. $1 \mathrm{~km}$ long high-velocity anomalies $(\mathrm{Vp} \sim 6.3 \mathrm{~km} / \mathrm{s}$ ) as compared to the background $\mathrm{Vp}$ velocity of $6.0 \mathrm{~km} / \mathrm{s}$ (Poppeliers, 2007). Greater thickness (400-600 m) of mafic sills in the lower crust has been reported for the Dnieper-Donets rift and the Baikal rift zone (Lyngsie et al., 2007; Thybo and Nielsen, 2009).

The depth at which lamellae develops is controlled by crustal rheology and, nearly always, a sialic/intermediate lower crust is the weakest part of the lithosphere (Burov and Watts, 2006; Handy and Brun, 2004; Meissner and Strehlau, 1982). The intruding magmas, however, may change the crustal rheology. Cooling magmas, which form subhorizontal sills connected by near-vertical (seismically invisible due to their orientation) feeding dykes, may form a threedimensional solid network (Meissner and Kern, 2008). In contrast to predictions of classical rheological models, this three-dimensional "corset" makes the lower crust rheologically strong, at least in areas of pronounced lamellae. This conclusion is supported by observations of undisturbed, continuous structure of seismic crustal lamellae across most of western/central Europe, below the Alpine and Pyrenees compressional orogens, and below several Mesozoic extensional basins around the British isles (Dyment et al., 1990). The presence of strikeslip earthquakes down to a $30 \mathrm{~km}$ depth north of the Alps (including occurrences in the laminated lower crust) further indicates that today the lower crust is rheologically strong (Meissner and Kern, 2008). A comparison of the depth range of crustal reflectivity with typical continental geotherms indicates that the reflectivity zone is limited by temperature of ca. $500{ }^{\circ} \mathrm{C}$ (Fig. 23b). This temperature approximately corresponds to the upper limit estimate for brittleductile transition temperatures in quartz and feldspar-rich rocks, typical of the continental crust.

It is worth mentioning that deep crustal reflectivity may have a multi-genetic origin. In particular, it can be caused not only by magmatic intrusions, but also by the presence of eclogite-facies rocks in the lower crust. In particular, high reflection coefficients (0.04-0.14) calculated for strongly foliated eclogite-facies rocks in a shear zone within the Norwegian Caledonides indicate that deep crustal seismic reflectors can be explained by the presence of eclogite-facies rocks in those portions of the crust that were subject to high-pressure conditions but did not experience high temperatures (Fountain et al. 1994). In addition to lithologic/igneous/metamorphic layering, crustal reflectivity can also be caused by the presence of shear zones (e.g. Austrheim et al., 1997; Mooney and Meissner, 1992).

\subsection{Reflections in the upper mantle}

Compared to the lower crust, the upper mantle usually lacks a coherent reflectivity. Although occasionally upper mantle reflections are observed (Yang, 2003), not all of them can be linked to the tectonic history of a special location (Asencio et al., 2003). Impedance contrasts are mostly positive (Warner et al., 1996) although some clear negative contrasts have been observed, for example, in a volcanic back-arc zone in New Zealand (Stratford and Stern, 2004).

Where isolated, often dipping, mantle reflectors are observed in the continental lithospheric mantle, they are related to past collisional and subduction processes. A spectacular reflectivity example is imaged by the URSEIS profile in the southern Urals (Knapp et al., 1996). While the uppermost mantle shows several dipping reflectors (apparently remnants of subduction zones), several strong, nearly sub-horizontal reflectors are observed at depths between $75 \mathrm{~km}$ and $175 \mathrm{~km}$. They can be associated with the continent-continent collision at the eastern edge of the East European craton but, because of the complex tectonic history of the Uralides orogen, any tectonic interpretation of mantle reflectivity should be made with caution.

Several locations in Europe with prominent sub-Moho reflections should be mentioned. One is the spectacular upper mantle reflectivity in northern Scotland, where two strong, sub-horizontal reflectors have been imaged by BIRPS near-vertical reflection surveys (Warner et al., 1996) and later confirmed by wide-angle and receiver function studies (Asencio et al., 2003). The reflectors have a positive polarity and apparently represent a pre-Caledonian subduction zone. Similarly, several dipping upper mantle reflections observed in the Baltic Shield (in the North Sea and the Baltic Sea) at depths of 30-90 km (Fig. 10) are interpreted as remnants of slabs subducted in the Proterozoic and Paleozoic (Abramovitz et al., 1997; Babel WG, 1990, 1993; Mona Lisa WG, 1997).

In contrast, no prominent mantle reflectors have been found below the Variscan terranes of western Europe (Figs. 19e, 22a), where reflectivity always terminates below the laminated lower crust, at the Moho, and even tests with reflection recording times up the $30 \mathrm{~s}$ did not show mantle reflectivity (Meissner, unpublished experiment). Delamination of the lowermost crust/lithospheric mantle in the postVariscan time together with high lithospheric temperatures and an intensive magmatism homogenized much of the upper mantle and destroyed the evidence of the previous tectonic processes. Possible location of former collisional zones can be constrained by several dipping reflectors that are present only in the rigid upper crust (Meissner and Bortfeld, 1990).

\section{How was the Variscan crust created?}

Several types of significantly different material exchange processes between the continental crust and the upper mantle have taken place in various tectonic units and at various time in Europe. Here we discuss some questions related to these interaction processes, concentrating on one of the largest and most problematic tectonic unit in Phanerozoic Europe, the Variscides.

\subsection{Major characteristics of the present-day Variscan lithosphere}

The characteristic and unusual features of the present-day lithosphere structure in Variscan Europe, which are described in detail earlier, can be summarized in the following:

(1) a thin (only $30 \mathrm{~km}$ ) continental crust;

(2) a flat and sharp Moho, which continues across major tectonic boundaries,

(3) the absence of a high-velocity lower crust,

(4) wide-spread seismic reflectivity (lamellae) in the lower crust with a sharp reflection Moho,

(5) general absence of upper mantle seismic reflectivity. 
Apparently, all these patterns are typical for the "extended" crust and are inter-related. For example, seismic refraction and reflection experiments demonstrate similar crustal features in the extended crust of the Basin and Range Province, western USA, where strong orogenic processes preceded the extension, as it was in the Paleozoic Variscides (Allmendinger et al., 1983, 1987; Gashawbeza et al., 2008; McCarthy and Thompson, 1988). Regional extension in the Basin and Range province is commonly explained by crustal "collapse"; the lower crustal flow further smoothed out crustal thickness variations caused by differential crustal extension and led to the creation of the anomalous crustal structure (McKenzie et al., 2000). Similar concepts supported by modeling (McKenzie, 1984) are favored for the Variscan area.

A characteristic feature of the extensional regime of the Basin and Range Province is the presence of metamorphic core complexes. The latter are surface exposures of middle and lower continental crust exhumed in association with largely amagmatic extension (Block and Royden, 1990). Typically metamorphic core complexes consist of an exposed high-grade metamorphic basement terrane and an unmetamorphosed cover, between which are low-angle detachment faults (mylonite shear zones) (Fig. 24a). Several metamorphic core complexes are recognized in Europe, e.g. in the Western and Central Carpathians and in the French Massif Central (Ciulavu et al., 2008; Echtler and Malavieille, 1990; Franke et al., 2011; Janák et al., 2001). The origin of the metamorphic core complex in the Massif Central is related to the collapse of the Variscan orogen at ca. 300 Ma when the compressional regime was followed by crustal extension, uplift, and denudation (Fig. 24b-d).

Clearly, today the Variscan crust of Europe appears to be more "extensional" than orogenic (Menard and Molnar, 1988). The Variscan orogenic roots were lost by oceanic and continental subduction, possibly supported by lithosphere delamination. In collisional orogens formed by closure of an ocean basin (such as the Paleozoic Variscides in Europe and the Tethyan Fold belt-Himalayas in Asia Minor-Central Asia) continental or arc subduction can develop in case of strong lithosphere rheology and high convergence rate. In contrast, if the lithosphere is weak and the convergence rate is low, the development of the Rayleigh-Taylor instability is a more likely scenario. In the former case, convergence is accommodated by internal deformation, while in the latter case by pure shear thickening. Extensional collapse of overthickened crust and the uppermost lithosphere (Menard and Molnar, 1988) and gravitational collapse caused by formation of eclogites (Le Pichon et al., 1997; Mengel and Kern, 1992) have been proposed as mechanisms responsible for the formation of thin crust in the European Variscides. Post-orogenic wrench tectonic and extension, probably initiated by the westward movement of Gondwana in the Permian, has transformed the Variscan orogen into a typical extensional structure (Matte, 1991; Menard and Molnar, 1988).

The post-orogenic extension in the Variscides is commonly explained by a stretching factor $\beta$ of 1.5 to 1.7 , assuming $45-50 \mathrm{~km}$
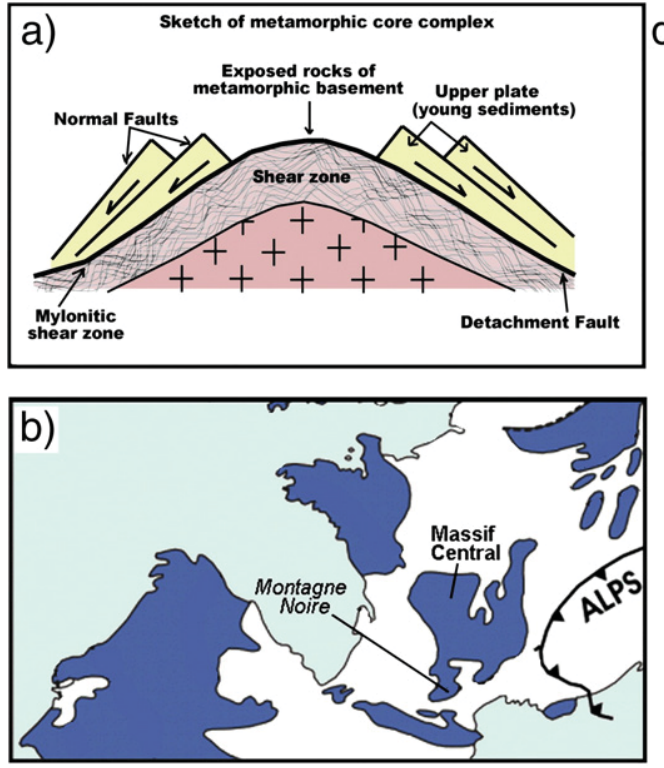

c)

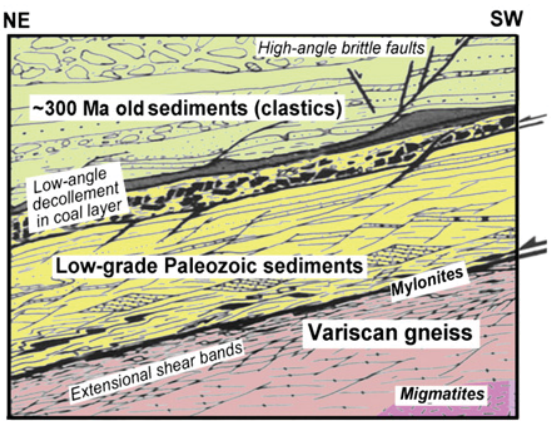

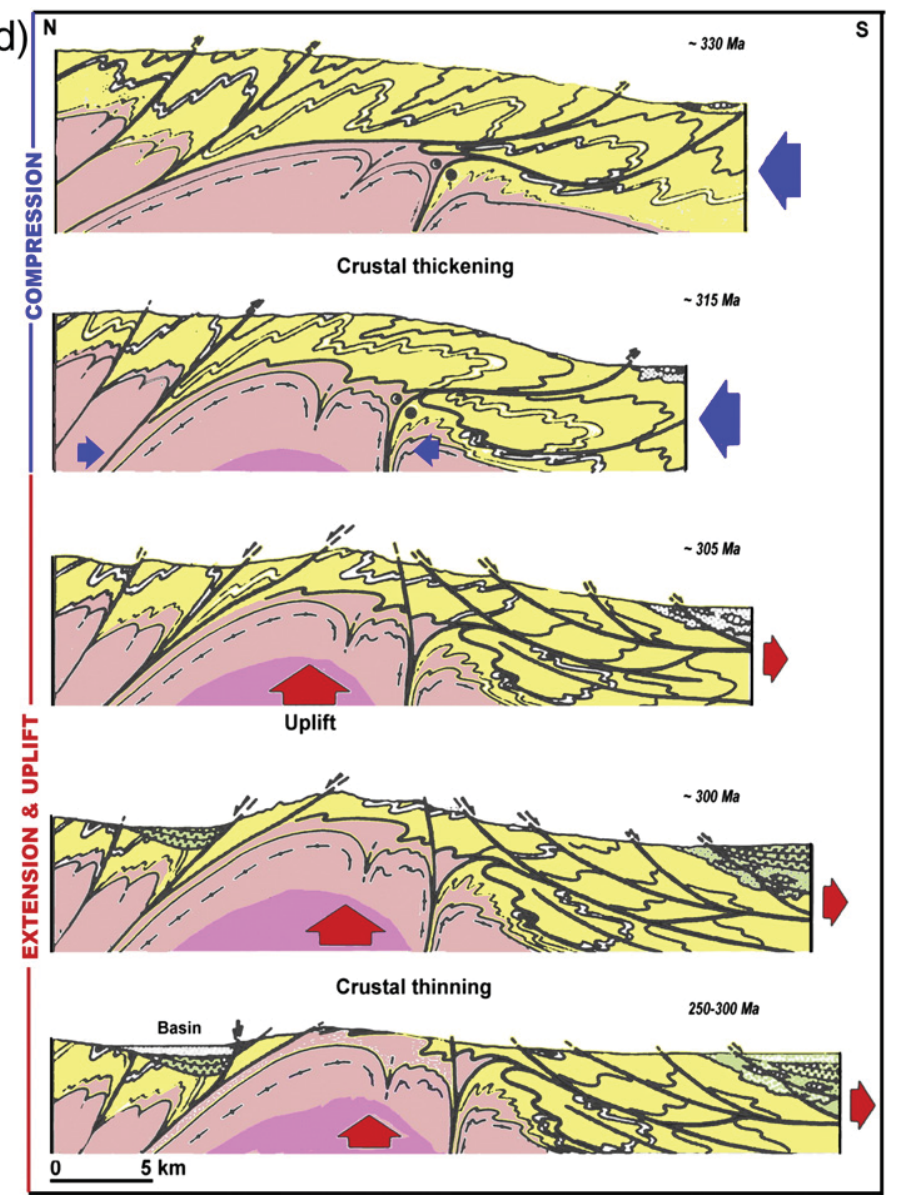

Fig. 24. Metamorphic core complexes (MCC), asymmetrical dome like structures, usually formed in regions of continental extension after gravitational collapse of thick crust. (a) Sketch (not to scale) illustrating the basic structure of a MCC, which consists of a metamorphic basement and an unmetamorphosed cover, separated by a decollement zone with mylonitic fabric. (b) Location of the Montagne Noire MCC in the southern Massif Central, France. (c) Sketch (not to scale) illustrating various deformation styles associated with the Late Carboniferous extensional tectonics in the Massif Central. (d) Evolutionary model for the various stages of Variscan deformation of the Montagne Noire MCC. Two upper plates refer to orogenic shortening, while three lower plates refer to late orogenic extensional tectonics and uplift of the thickened core zone. The latter is advanced by migmatization and anatectic granite emplacement. Development of Permian sedimentary basins (bottom plate) is controlled by high-angle normal faulting ((c-d) modified after Echtler and Malavieille, 1990). 
for the average thickness of the pre-extensional crust of the Variscan orogen and $30 \mathrm{~km}$ for its present-day thickness. Similar values of the $\beta$-factor are commonly estimated for extensional areas worldwide, including the Basin and Range Province (Gans, 1987). This simple stretching model allows for an additional 7-8 km of crustal thickening by mafic magmas. This value is certainly a large overestimation since the total thickness of mafic intrusions in the present-day Variscan lower crust does not exceed 1-2 km. Larger volumes of intrusions would have increased average seismic velocities, in contrast to seismic observations in the Variscides (Fig. 17b). However, possibly an equivalent of 7-8 km thick layer of mafic magmas is introduced not into the lower crust but accumulated below the Moho (underplated).

\subsection{Why is the mafic lower crust missing?}

Two scenarios can explain the absence of the crustal roots beneath the Paleozoic orogens on Europe and the missing mafic lower crust in extensional areas. They describe a possible sequence of crust-mantle material exchange mechanisms during or after main orogenic events and are directly applicable to the European Variscides.

According to a scenario originally proposed for the main Appalachians (Nelson, 1992) and for the Paleozoic orogens of Europe (Franke, 1992) and later examined numerically for the Variscan and the Himalayan orogenies (Schott and Schmeling, 1998), the crustal thinning occurs at the final stages of compression by subduction(s) and delamination of thickened, eclogitized lower crust and uppermost lithospheric mantle (Fig. 25). The presence of eclogites in lower crustal xenoliths from the Variscan Europe (Downes, 1993) suggests that this scenario is plausible. Post-orogenic extension initiates the rise of mantle magmas, produced by decompression melting of the upwelling asthenosphere. These rising asthenospheric (mafic-ultramafic) magmas replace delaminated lithosphere and form a new shallow upper mantle with a sharp and flat Moho, identical in both reflection and refraction seismics (Meissner and Bortfeld, 1990). Heat from the rising magma initiates melting of the sialic crust leading to the formation of granitic bodies in the crust (Fig. 7), widespread in Variscan Europe (Lliboutry, 1999; Oncken, 1994). Mafic-ultramafic magma that enters the crust forms sills in its lower, rheologically favorable, horizons. Thus formed lamellae and the new widespread flat and shallow Moho are present today below most (extensional) areas of westcentral Europe, including rifts and basins. High mantle temperatures during the extension phase have dissolved sharp structural and compositional boundaries in the lithospheric mantle so that no mantle reflectors exist at present. An indirect support for this scenario comes from the isotope data on the lower crustal xenoliths which indicate that the age of the lower crust beneath the Variscan terranes is often younger that the age of near-surface rocks. These results are interpreted as an evidence that magmatic intrusions and underplating during periods of subduction, rifting and orogenic collapse in the Variscides added a significant portion of the mafic lower crust to the base of the pre-existing crust (Downes, 1993).

An alternative scenario for the missing mafic lower crust beneath the Paleozoic orogens of western Europe has been proposed by Berthelsen (1998). In this model, the former mafic lower crust undergoes partial eclogitisation. A new seismic Moho is formed on top of the eclogite-facies layer which (being made of a mixture of basaltic and eclogitic rocks) can be seismically undistinguishable from the underlying mantle peridotite, whereas the "petrologic Moho" remains at the base of the eclogite-facies layer. Although this scenario may explain seismic observations of a thin, two-layered crust beneath the Variscides, it is difficult to imagine that large-scale lower crustal eclogitization was able to modify the crust of most of western Europe during a few hundred millions of years; tectonic analogues operating on such a scale are not well documented but similarities have been proposed for the Variscides, Tibet and the Andes (Le Pichon et al., 1997). Some anisotropy patterns observed within the Variscan terranes also cannot be easily explained by this mechanism (Section 4.2), and this scenario is in conflict with younger isotope ages of the lower crustal rocks than of the overlying rocks (Downes, 1993).

\subsection{Unanswered questions}

Both scenarios described in Section 5.2 provide mechanisms how the crust which formed during a large-scale Paleozoic orogeny may have lost or chemically changed its lower parts to become thin and uniform as it is seismically observed at present. It is, however, still a mystery what was the sequence of tectonic events that formed such a uniform "extensional" crust over the whole of western and central Europe. Apparently, only a combination of massive tectonic extensional stresses with an extensive, continent-scale, Variscan or/and post-Variscan heating event could possibly have created a uniform crust over such a huge area, and one has to acknowledge a widespread

\section{From compression to extension}

\section{Phase I: Compression and subduction}

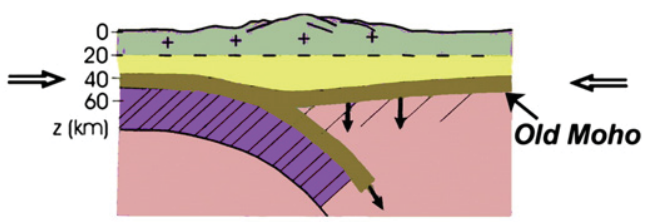

Phase III: Extension, uplift of mafic magmas

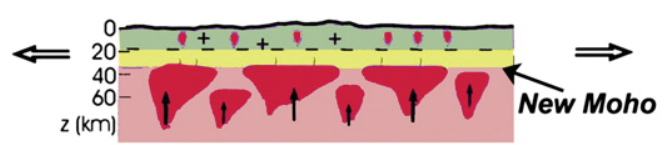

Phase II: Subduction and delamination, sinking of eclogite bodies

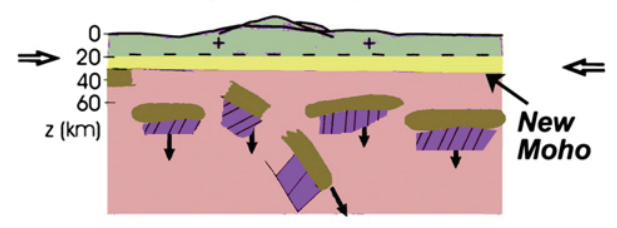

Phase IV: Extension, intrusion of dykes and sills into the lower crust

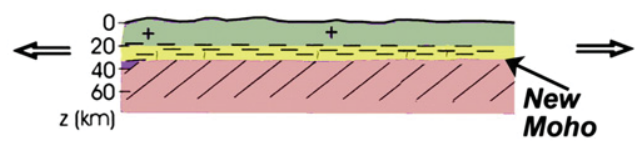

Fig. 25. Sketch illustrating the transition from compressional to extensional tectonic regime. (I) Tectonic compression leads to mountain building and subduction of lithospheric plate, enhanced by eclogitization of the lower crustal material. (II) As a result of delamination of thickened, eclogitized lower crust and uppermost lithospheric mantle, crustal thinning occurs at the final stages of compression. (III) Decompression melting of the upwelling asthenosphere during post-orogenic extension initiates the rise of mantle magmas, which replace delaminated lithosphere and form a new shallow upper mantle with a sharp and flat Moho. (IV) Crustal heating by rising magmas initiates its melting with the formation of granitic plutons (not shown), while mafic-ultramafic magmas that enter the lower crust form reflecting sills (seismic lamellae). 
large-scale material exchange processes between the crust and mantle of Europe.

Many more problems still remain to be explained for the Variscan lithosphere of Europe. Some of them are listed below.

(1) Wide-spread eclogitization of the Variscan lower crust is problematic. The timing of the eclogitization raises further questions. The situation in the North German Basin is especially challenging: major subsidence in the basin occurred in the Permo-Triassic when more than $10 \mathrm{~km}$ of sediments were accumulated there (Fig. 20a). Given that the present Moho is at ca. $30 \mathrm{~km}$ depth, it means that the thickness of the crystalline crust was reduced to less than $20 \mathrm{~km}$, that is by more than 30\%. Furthermore, a ca. $10-\mathrm{km}$ thick high-velocity layer with P-wave velocity of $6.9-7.5 \mathrm{~km} / \mathrm{s}$ has been detected in the lower crust north of the Elbe river in an area of ca. $150 \times 180 \mathrm{~km}$ by a network of deep seismic refraction profiles in Northern Germany (Rabbel et al., 1995). It is difficult to imagine that a significant portion of the lower crust could have been eclogitized during the last few hundred million years even though the rate of the eclogitization process is not well constrained.

We thus suspect that the formation of the shallow Moho is relatively recent and it occurred when rising (probably piclogitic) magmas achieved gravitational equilibrium. This hypothesis is in accord with an explanation of the origin of the high-velocity lower crustal body beneath the North German Basin by infiltration of mafic magmas during the extensional stage (Rabbel et al., 1995), although greenshist facies to amphibolite facies metamorphism of the lower crust was also proposed as a possible mechanism (Brink, 2005). Anderson (2007) argues that lithosphere heating may cause a "Yo-Yo" tectonics giving rise to eclogitic blobs and their mixing with peridotite to form "piclogite". Major element composition of these piclogites is intermediate between dunites and basalts but with a larger basalt fraction than peridotites, so that their P-velocity is ca. $8 \mathrm{~km} / \mathrm{s}$ (e.g. Given and Helmberger, 1981). These piclogites are likely to be a main component of rising asthenospheric material that forms the new Moho, the new upper mantle and also mafic intrusions into the lower crust. Their possible presence, seismically undetectable, however should have a strong effect on crustal/lithospheric buoyancy.

(2) The sequence of tectonic processes described above (Fig. 25), from compression to extension, is not the only way to create extensional continental crust. Heterogeneous seismic velocity structure of Phanerozoic Europe (Fig. 17b), although to a large extent due to significant lateral temperature variations, suggests that some remnants of delaminated and subducted lithosphere can still be present in the upper mantle of the Variscides (Bijwaard and Spakman, 2000; Piromallo and Morelli, 2003). In particular, mantle Vp/Vs velocity models (that are weakly sensitive to regional temperature variations in the mantle but are more sensitive to compositional variations) indicate significant compositional heterogeneity in the upper mantle of the Variscides down to at least $200 \mathrm{~km}$ depth (e.g. Artemieva, 2009; Artemieva et al., 2006), although sharp structural and compositional boundaries in the mantle (as evidenced by the absence of mantle seismic reflections) may have been eliminated by very high (homogenizing) temperatures during lithosphere extension.

(3) The sequence of the formation of granites and seismic lamellae in the crust poses another problem. There are no definite signs for the generation of granites inside the lamellae of the lower crust, and one has to assume that the mafic sills were formed after granitic plutons, at least in those areas where granitic intrusions are present and seismic lamellae have a very regular pattern.
The regularity of the lamellae raises another question. Surprisingly, the lamellae do not show any preference (or systematic variation) regarding their depth distribution and intensity within the lower crust. Since the lowermost layer is the hottest part of the crust and its viscosity should be the lowest, it should facilitate intrusions of magmas leading to an increase of seismic reflectivity. Surprisingly, the regular depth pattern of lamellae, which indicates a similar density and thickness of intruding sills, suggests a constant lower crustal viscosity.

(4) A special problem for the Variscan orogeny is the question whether the colliding Paleozoic terranes that formed most of the western-central European crust (Figs. 13-15) had a "shield-like" three-layer pre-collisional crust. One cannot exclude the possibility that the terranes that came from the northern rim of Gondwanaland were possibly already "extensional" and the mafic lower crust was already absent there. Such an assumption could provide an additional explanation for the absence of a thick mafic lower crust in west-central Europe and for the timing of post-Variscan tectonic processes in Europe, reducing the role of crustal eclogitization in the formation of the present-day crust.

\section{Conclusions}

Global interaction processes between crust and mantle, many of which are manifestations of plate tectonic processes, have determined the development of the crustal structure of the Earth. A comparison of the ratio of crust-to-mantle volume on the terrestrial planets suggests that plate tectonic processes, together with crustal eclogitization, may be important in limiting the total thickness and total volume of the crust. On Earth, crustal volume is effectively controlled by subduction (oceanic or continental) and delamination which recycle crustal (lithospheric) material into the mantle and reduce its volume. Working in the opposite direction, magmatic intrusions, underplating and exhumation create new crust and can increase the volume of the existing crust. Consequently, crustal thickness may be reduced during magmo-tectonic events, given that magmatism is nearly always associated with lithosphere extension.

Crustal structure as revealed by seismic data preserves the record of past tectonic processes responsible for its formation and structural and chemical modification. The role of material exchange processes in shaping the structure of the continental crust is illustrated using the European continent as an example, with focus on the structure of the present-day crust of the Variscan terranes the origin of which is still highly debated. This crust, created as a result of large-scale Caledonian and Variscan orogenies, did not preserve orogenic crustal roots but instead has all present-day characteristics of the extended continental crust. Understanding the origin of the anomalous "extensional" crust in the European Variscides requires understanding:

(i) the origin of flat Moho, thin crust, and low lower crustal velocities;

(ii) the origin of lower crustal reflectivity (lamellae) in the European Variscides and absence of mantle reflectivity in most of Europe;

(iii) the role of basalt/gabbro-eclogite phase transition in limiting crustal thickness worldwide, including depth-temperature variations for this transition in different tectonic provinces of Europe and conditions for a long-time preservation of thick crustal roots beneath stable continental interior;

(iv) the links between crustal recycling, mafic magmatism, sills and crustal underplating, and their effects on crustal rheology.

We conclude that there are several possible scenarios of the postVariscan evolution of the crust of western-central Europe which leave the open questions that still await to be answered. 


\section{Acknowledgments}

Two anonymous reviews and comments of $\mathrm{H}$. Thybo to the early version of the manuscript are appreciated. The study is supported by FNU-Denmark grant to IMA.

\section{References}

Abbott, D.H., Hoffman, S.E., 1984. Archean plate tectonics revisited 1: Heat flow, spreading rate, and the age of subducting oceanic lithosphere, and their effects on the origin and evolution of continents. Tectonics 3, 429-448.

Abbott, D., Menke, W., 1990. Length of the global plate boundary at $2.4 \mathrm{Ga}$. Geology 18 , 58-61.

Abbott, D., Burgess, L., Longhi, J., Smith, W., 1994. An empirical thermal history of the Earth's upper mantle. Journal of Geophysical Research 99 (B7), 13835-13850.

Abramovitz, T., Berthelsen, A., Thybo, H., 1997. Proterozoic sutures and terranes in the southeastern Baltic Shield interpreted from BABEL deep seismic data. Tectonophysics 270, 259-277.

Abramovitz, T., Thybo, H., MONA LISA Working Group, 1998. Seismic structure acros the Caledonian Deformation Front along MONA LISA profile 1 in the southeastern North Sea. Tectonophysics 288, 153-176.

Ahrens, T.J., Schubert, G., 1975. Gabbro-eclogite reaction-rate and its geophysical significance. Reviews of Geophysics and Space Physics 13, 383-400.

Aichroth, B., Prodehl, C., Thybo, H., 1992. Crustal structure along the central segment of the EGT from seismic-refraction studies. Tectonophysics 207, 43-64.

Allègre, C.J., 1982. Chemical geodynamics. Tectonophysics 81, 109-132.

Allmendinger, R.W., Sharp, J.W., Vontish, D., Serpa, L., Brown, L., Kaufman, S., Oliver, J. Smith, R.B., 1983. Cenozoic and Mesozoic structure of the eastern Basin and Range province from COCORP seismic reflection data. Geology 11, 532-536.

Allmendinger, R.W., Hauge, T.A., Hauser, E.C., Potter, C.J., Oliver, J., 1987. Tectonic heredity and the layered lower crust in the Basin and Range Province. Geological Society Special Publication 28, 223-246.

Anderson, D.L., 2007. New Theory of the Earth. Cambridge University Press. 379 pp.

Anderson, F.S., Smrekar, S.E., 2006. Global mapping of crustal and lithospheric thickness on Venus. Journal of Geophysical Research 111, E08006. doi:10.1029/ 2004JE002395.

Anell, I., Thybo, H., Artemieva, I.M., 2009. Cenozoic uplift and subsidence in the North Atlantic region: geological evidence revisited. Tectonophysics 474, 78-105.

Armstrong, R.L., 1981. Radiogenic isotopes: the case for crustal recycling on a nearsteady-state no-continental growth Earth. Philosophical Transactions of the Royal Society of London, Series A: Mathematical, Physical and Engineering Sciences 301, 443-472.

Artemieva, I.M., 2003. Lithospheric structure, composition, and thermal regime of the East European craton: implications for the subsidence of the Russian Platform. Earth and Planetary Science Letters 213, 429-444.

Artemieva, I.M., 2006. Global $1^{\circ} \times 1^{\circ}$ thermal model TC 1 for the continental lithosphere: implications for lithosphere secular evolution. Tectonophysics 416, 245-277.

Artemieva, I.M., 2007. Dynamic topography of the East European Craton: shedding light upon the lithospheric structure, composition and mantle dynamics. Global Planetary Change 58, 411-434.

Artemieva, I.M., 2009. The continental lithosphere: reconciling thermal, seismic, and petrologic data. Lithos 109, 23-46.

Artemieva, I.M., 2011. The lithosphere: An Interdisciplinary Approach. Cambridge University Press. $794 \mathrm{pp}$.

Artemieva, I.M., Mooney, W.D., 2001. Thermal structure and evolution of Precambrian lithosphere: a global study. Journal of Geophysical Research 106, 16387-16414.

Artemieva, I.M., Mooney, W.D., 2002. On the relation between cratonic lithosphere thickness, plate motions, and basal drag. Tectonophysics 358, 211-231.

Artemieva, I.M., Thybo, H., 2008. Deep Norden: Highlights of the lithospheric structure of Northern Europe, Iceland, and Greenland. Episodes 31 (1), 98-106.

Artemieva I.M., Thybo H., 2012. Crustal structure of Europe, Greenland, and the North Atlantic region: Synthesis and analysis. In: Artemieva I.M., L. Brown, B. Kennett, H. Thybo (Eds.), Moho: 100 years after Andrija Mohorovičić. Tectonophysics Special Issue (in submission)

Artemieva, I.M., Thybo, H., Kaban, M.K., 2006. Deep Europe today: geophysical synthesis of the upper mantle structure and lithospheric processes over 3.5 Ga. Geological Society of London, Memoirs 32, 11-41.

Artyushkov, E.V., 1993. Physical Geotectonics. Nauka, Moscow. 455 pp.

Asencio, E., Knapp, J.H., Owens, T.J., Helfrich, G., 2003. Mapping fine-scale heterogeneities with the continental mantle lithosphere beneath Scotland: combining activeand passive-source seismology. Geology 6, 477-480.

Ashwal, L.D., 2010. The temporality of anorthosites. The Canadian Mineralogist 48, 711-728.

Atwater, T., Stokes, J., 1998. Pacific North America plate tectonics of the Neogene southwestern United States: an update. International Geology Review 40, 375-402.

Austrheim, H., Erambert, M., Engvik, A.K., 1997. Processing of crust in the root of the Caledonian continental collision zone: the role of eclogitization. Tectonophysics 273, 129-153.

BABEL Working Group, 1990. Evidence for early Proterozoic plate tectonics from seismic reflection profiles in the Baltic Shield. Nature 348, 34-38.

BABEL Working Group, 1993. Deep seismic reflection/refraction interpretation of crustal structure along BABEL profiles A and B in the southern Baltic Sea. Geophysical Journal International 112, 243-325.
Babuška, V., Plomerová, J., 1992. The lithosphere in central Europe-seismological and petrological aspects. Tectonophysics 207, 141-163.

Babuška, V., Plomerová, J., Vecsey, L., Granet, M., Achauer, U., 2002. Seismic anisotropy of the French Massif Central and predisposition of Cenozoic rifting and volcanism by Variscan suture hidden in the mantle lithosphere. Tectonics 21 (4), 11-1-11-20.

Balling, N., 2000. Deep seismic reflection evidence for ancient subduction and collision zones within the continental lithosphere of northwestern Europe. Tectonophysics 329, 269-300.

Barth, M., McDonough, W.F., Rudnick, R.L., 2000. Tracking the budget of Nb and Ta in the continental crust. Chemical Geology 165, 197-213.

Bauer, K., Trumbull, R.B., Victor, T., 2003. Geophysical images and a crustal model of intrusive structures beneath the Messum ring complex in Nabimia. Earth and Planetary Science Letters 216, 65-80.

Bayer, U., Scheck, M., Hauf, Y., 1995. Structural evolution of the Northeast German Basin during Early Permian to Keuper-volumetric analysis of sediment accumulation. Terra Nostra 95, 80-89.

Bayer, U., Scheck, M., Rabbel, W., Krawczyk, C.M., Götze, H.-J., Stiller, M., Beilecke, Th. Marotta, A.-M., Barrio-Alvers, L., Kuder, J., 1999. An integrated study of the NE German Basin. Tectonophysics 314, 285-307.

Beck, S.L., 2002. The nature of orogenic crust in the central Andes. Journal of Geophysical Research 107 art. No. 2230.

Behm, M., Bruckl, E., Chwatal, W., Thybo, H., 2007. Application of stacking and inversion techniques to three-dimensional wide-angle reflection and refraction seismic data of the Eastern Alps. Geophysical Journal International 170, 275-298.

Behr, H.J., Heinrichs, T., 1987. Geological interpretation of DEKORP 2-S: a deep seismic reflection profile across the Saxothuringian and possible implications for the Late Variscan structural evolution of Central Europe. Tectonophysics 142, 173-202.

Belousova, E.A., Kostitsyn, Y.A., Griffin, W.L., Begg, G.C., O'Reilly, S.Y., Pearson, N.J., 2010. The growth of the continental crust: constraints from zircon Hf-isotope data. Lithos 119, 457-466.

Bercovici, D., Ricard, Y., Richards, M.A., 2000. The relation between mantle dynamics and plate tectonics: a primer. In: Richards, M.A., Gordon, R., van der Hilst, R. (Eds.), History and Dynamics of Global Plate Motions. : Geophys. Monogr., 121. American Geophysical Union, Washington, DC, pp. 5-46.

Berthelsen, A., 1998. The Tornquist Zone northwest of the Carpathians: an intraplate pseudosuture. GFF 120, 223-230.

Berzin, R., Oncken, O., Knapp, J.H., Perez-Estaun, J.H., Hismatulin, A., Yunusov, N., Lipilin, A., 1996. Orogenic evolution of the Ural Mountains: results from an integrated experiment. Science 274, 220-221.

Bijwaard, H., Spakman, W., 2000. Non-linear global P-wave tomography by iterated linearized inversion. Geophysical Journal International 141, 71-82.

Bilgili, F., Götze, H.J., Pasteka, R., Schmict, S., Hackney, R., 2007. Intrusion versus Inversiona 3D density model of the southern rim of the Northwest German Basin. International Journal of Earth Sciences (Geologische Rundschau). doi:10.1007/s00631-007-0257-y.

Bird, P., 1979. Continental delamination and the Colorado Plateau. Journal of Geophysical Research 84, 7561-7571.

Bird, P., Liu, Z., Rucker, W.K., 2008. Stresses that drive the plates from below: definitions, computational path, model optimization, and error analysis. Journal of Geophysical Research B 113, 11406. doi:10.1029/2007JB005460.

Blanco, M.J., Spakman, W., 1993. The P-wave velocity structure of the mantle below the Iberian Peninsula: evidence for subducted lithosphere below southern Spain. Tectonophysics 221, 13-34.

Block, L., Royden, L., 1990. Core complex geometries and regional scale flow in the lower crust. Tectonics 9, 557-567.

Blundell, D., Freeman, R., Mueller, S. (Eds.), 1992. A Continent Revealed. The European Geotraverse. Cambridge University Press. 275 pp.

Bourdon, B., Touboul, M., Caro, G., et al., 2008. Early differentiation of the Earth and the 2228 Moon. Philosophical Transactions of the Royal Society A 366 (1883), 4105-4128.

Boutelier, D.A., Cruden, A., 2008. Impact of regional mantle flow on subducting plate geometry and interplate stress: insights from physical modelling. Geophysical Journal International 174, 719-732.

Boutelier, D., Chemenda, A., Jorand, C., 2004. Continental subduction and exhumation of high-pressure rocks: insight from thermo-mechanical laboratory modeling. Earth and Planetary Science Letters 222, 209-216.

Boyet, M., Carlson, R.W., 2005. ${ }^{142} \mathrm{Nd}$ evidence for early (4.53 Ga) global differentiation of the silicate Earth. Science 309, 576-581.

Breitsprecher, K., Thorkelson, D.J., Groome, W.G., et al., 2003. Geochemical confirmation of the Kula-Farallon slab window beneath the Pacific Northwest in Eocene time. Geology 31, 351-354.

Brink, H.--., 2005. The evolution of the North German Basin and the metamorphism of the lower crust. International Journal of Earth Sciences (Geologische Rundschau) 94, 1103-1116.

Bromley, A.V., Holl, C.J., 1986. Mineral Processing at a Crossroads. Kluwer Acad. Publ.

Burov, E.B., Watts, A.B., 2006. The long-term strength of continental lithosphere: "jelly sandwich" or "crème brûlée"? GSA Today 16, 1. doi:10.1130/10525173(2006) 016

Calvert, A.J., Sawyer, E.W., Davis, W.J., Ludden, J.N., 1995. Archean subduction inferred from seismic images of a mantle suture in the Superior province. Nature 375, 670-674.

Calvert, A., Sandvol, E., Seber, D., et al., 2000. Geodynamic evolution of the lithosphere and upper mantle beneath the Alboran region of the western Mediterranean: constraints from travel time tomography. Journal of Geophysical Research 105, 10871-10898.

Campbell, I.H., Griffiths, R.W., 1992. The changing nature of mantle hotspots through time: implications for the chemical evolution of the mantle. Journal of Geology 92, 497-523. 
Canales, J.P., Nedinovi, M.R., Kent, G.M., Carbotte, S.M., Detrik, R.S., 2009. Seismic reflection images of a near-axis melt sill within the lower crust at the Juan de Fuca ridge. Nature 460, 89-93.

Canup, R., 2004. Simulation of a late lunar-forming impact. Icarus 168, 433-456.

Carbonell, R., Perez-Estaun, A., Gallart, J., Diaz, J., Kashubin, S., Mechie, J., Stadtlander, R., Schulze, A., Knapp, J.H., Morozov, A., 1996. A crustal root beneath the Urals: wideangle seismic evidence. Science 274, 222-224.

Carlson, R., 2011. Geodynamic Controls on the Chemical Structure of the Mantle. IUGG Prog. and Abstr., Melbourne, Abstract \# 2776.

Carlson, R.W., Lugmair, G.W., 1988. The age of ferroan anorthosite 60025: oldest crust on a young Moon. Earth and Planetary Science Letters 90, 119-130.

Caro, G., Bourdon, B., 2010. Non-chondritic Sm/Nd ratio in the terrestrial planets: consequences for the geochemical evolution of the mantle-crust system. Geochimica et Cosmochimica Acta 74, 3333-3349.

Castellarin, A., Cantelli, L., 2000. Neo-Alpine evolution of the Southern Eastern Alps. Journal of Geodynamics 30, 251-274.

Catling, D.C., 2004. On Earth, as it is on Mars? Nature 429, 707-708.

Cavazza, W., Roure, F., Spakman, W., Stampfli, G.M., Ziegler, P.A. (Eds.), 2004. The TRANSMED Atlas-The Mediterranean Region from Crust to Mantle. Springer, Berlin, Heidelberg. 141 pp. and CD-ROM.

Cawood, P.A., Kröner, A., Pisarevsky, S., 2006. Precambrian plate tectonics: criteria and evidence. GSA Today 16 (7), 4-11.

Chian, D., Marillier, F., Hall, J., Quinlan, G., 1998. An improved velocity model for the crust and upper mantle along the central mobile belt of the Newfoundland Appalachian orogen and its offshore extension. Canadian Journal of Earth Sciences 35, 1238-1251.

Choukroune, P., 1989. The ECORS Pyrenean deep seismic profile reflection data and the overall structure of an orogenic belt. Tectonics 8, 23-39.

Christensen, N.I., Mooney, W.D., 1995. Seismic velocity structure and composition of the continental crust: a global view. Journal of Geophysical Research 100,9761-9788.

Christensen, N.I., Medaris, L.G., Wang, H.F., Jelinek, E., 2001. Depth variation of seismic anisotropy and petrology in central European lithosphere: a tectonothermal synthesis from spinel lherzolite. Journal of Geophysical Research 106, 645-664.

Ciulavu, M., Mählmann, R.F., Schmid, S.M., Hofmann, H., Seghedi, A., Frey, M., 2008. Metamorphic evolution of a very low- to low-grade metamorphic core complex (Danubian window) in the South Carpathians. Geological Society of London, Special Publications 298, 281-315. doi:10.1144/SP298.14.

Clark, P.E., 2007. Dynamic Planet: Mercury in the Context of its Environment. Springer, New York. 219 pp.

Clegg, B., England, R., 2003. Velocity structure of the UK continental shelf from a compilation of wide-angle and refraction data. Geological Magazine 140 (4), 453-467.

Clemens, J.D., 2006. Melting of the continental crust: fluid regimes, melting reactions, and source-rock fertility. In: Brown, M., Rushmer, T. (Eds.), Evolution and Differentiation of the Continental Crust. Cambridge Univ. Press, pp. 296-330.

Cloetingh, S.A.P.L., Burov, E., Matenco, L., 2004. Thermo-mechanical controls on the mode of continental collision in the SE Carpathians (Romania). Earth and Planetary Science Letters 218, 57-76

Clowes, R.M., White, D.J., Hajnal, Z., 2010. Mantle heterogeneities and their significance: results from Lithoprobe seismic reflection and refraction-wide-angle reflection studies. Canadian Journal of Earth Sciences 47, 409-443.

Cocks, L.R.M., McKerrow, W.S., van Staal, C.R., 1997. The margins of Avalonia. Geological Magazine 134, 627-636.

Coldwell, B., Clemens, J., Petford, N., 2011. Deep crustal melting in the Peruvian Andes: felsic magma generation during delamination and uplift. Lithos 125, 272-286.

Coltice, N., Albarede, F., Gillet, P., 2000. K-40-Ar-40 constraints on recycling continental crust into the mantle. Science $288,845-847$

Condie, K.C., 1994. Greenstones through time. In: Condie, K.C. (Ed.), Archean Crustal Evolution. Elsevier, Netherlands, pp. 85-120.

Condie, K.C., 1998. Episodic continental growth and supercontinents: a mantle avalanche connection? Earth and Planetary Science Letters 163, 97-108.

Condie, K.C., 2004. Supercontinents and superplume events: distinguishing signals in the geologic record. Physics of the Earth and Planetary Interiors 146, 319-332.

Condie, K.C., Pease, V. (Eds.), 2008. When did plate tectonics begin on planet Earth? Geological Society of America Memoirs, Sp. Paper, 440. 313 pp.

Connerney, J.E.P., Acuña, M.H., Wasilewski, P.J., Ness, N.F., Rème, H., Mazelle, C., Vignes, D., Lin, R.P., Mitchell, D.L., Cloutier, P.A., 1999. Magnetic lineation in the ancient crust of Mars. Science 284, 794-798.

Cook, F.A., Matthews, D.H., Jacob, A.W.B., 1988. Geophysics of the Caledonian-Appalachian Orogen. Geological Society of London, Special Publications 38, 21-33.

Cruden, A.R., McCaffrey, K.J.W., 2001. Growth of plutons by floor subsidence: implications for rates of emplacement, intrusion spacing and melt-extraction mechanisms. Physics and Chemistry of the Earth, Part A 26, 303-315.

Dahl-Jensen, T., Larsen, T.B., Woelbern, I., et al., 2003. Depth to Moho in Greenland: receiver-function analysis suggests two Proterozoic blocks in Greenland. Earth and Planetary Science Letters 205, 379-393.

Dando, B.D.E., Stuart, G.W., Houseman, G.A., et al., 2011. Teleseismic tomography of the mantle in the Carpathian-Pannonian region of central Europe. Geophysical Journal International 186, 11-31.

Dauphas, N., Cates, N.L., Mojzsis, S.J., et al., 2007. Identification of chemical sedimentary protoliths using iron isotopes in the $>3750$ Ma Nuvvuagittuq supracrustal belt, Canada. Earth and Planetary Science Letters 254, 358-376.

Davies, G.F., 1999. Dynamic Earth. Cambridge Univ. Press, Cambridge. 458 pp.

Davies, G., 2011. Dynamical Geochemistry of the Mantle. IUGG Prog. and Abstr., Melbourne, Abstract \# 3020.

de Saint Blanquat, M., Horsman, E., Habert, G., et al., 2011. Multiscale magmatic cyclicity, duration of pluton construction, and the paradoxical relationship between tectonism and plutonism in continental arcs. Tectonophysics 500, 20-33.
De Wit, M.J., 1998. On Archean granites, greenstones, cratons and tectonics: does the evidence demand a verdict? Precambrian Research 91, 181-226.

DEKORP-BASIN Research Group, et al., 1999. The deep crustal structure of the Northeast German basin: new DEKORP-Basin'96 deep-profiling results. Geology 27, $55-58$

Dewey, J.F., 2007. The secular evolution of plate tectonics and the continental crust: an outline. In: Hatcher, R.D., et al. (Ed.), 4-D framework of continental crust: GSA Mem., 200, pp. 1-7.

Dewey, J.F., Windley, B.F., 1981. Growth and differentiation of the continental crust. Philosophical Transactions of the Royal Society of London-Series A 301, 189-206.

Di Luzio, E., Mele, G., Tiberti, M.M., Cavinato, G.P., Parotto, M., 2009. Moho deepenin and shallow upper crustal delamination beneath the central Apennines. Earth and Planetary Science Letters 280, 1-12.

Doin, M.-P., Fleitout, L., Christensen, U., 1997. Mantle convection and stability of depleted and undepleted continental lithosphere. Journal of Geophysical Research 102, 2771-2787.

Douce, A.E.P., 1999. What do experiments tell us about the relative contributions of crust and mantle to the origin of granitic magmas? Geological Society of London, Special Publications 168, 55-75.

Downes, H., 1993. The nature of the lower continental crust of Europe: petrological and geochemical evidence from xenoliths. Physics of the Earth and Planetary Interiors 79, 195-218

Druzhinin, V.S., Egorkin, A.V., Kashubin, S.N., 1990. New data on the deep structure of the Urals and adjacent regions from DSS studies. Doklady Akademii Nauk SSSR 315 (5), 1086-1090 (in Russian).

Dyment, J., Sibuet, J.C., Pinet, B., 1990. Deep structure of the Celtic Sea : a discussion on the formation of basins. Tectonophysics $173,435-444$.

Ebinger, C.J., Sleep, N.H., 1998. Cenozoic magmatism throughout east Africa resulting from impact of a single plume. Nature 395, 788-791.

Echtler, H., Malavieille, J., 1990. Extensional tectonics, basement uplift and StephanoPermian collapse basin in a late Variscan metamorphic core complex (Montagne Noire, Southern Massif Central). Tectonophysics 177, 125-138.

Echtler, H.P., Stiller, M., Steinhoff, F., Krawczyk, C., Suleimanov, A., Spiridonov, V., Knapp, J.H., Menshikov, Y., Alvarez-Marrón, J., Yunusov, N., 1996. Preserved collisional crustal structure of the southern Urals revealed by Vibroseis profiling. Science 274, 224-226

Eggler, D.H., Meen, J.K., Welt, F., Dudas, F.O., Furlong, K.P., McCallum, M.E., Carlson, R.W. 1988. Tectonomagmatism of the Wyomimg Province. Cenozoic volcanism in the Southern Rocky Mountains revisited. A tribute to Rudy C. Epis. Part 3: Colorado School of Mines Quarterly, vol. 83, pp. 25-40. No. 2

England, P.C., Houseman, G.A., 1989. Extension during continental convergence with application to the Tibetan Plateau. Journal of Geophysical Research 94, 17561-17579.

EUROBRIDGE Seismic Working Group, 1999. Seismic velocity structure across Fennoscandia-Sarmatia suture of the East European craton beneath the EUROBRIDGE profile through Lithuania and Belarus. Tectonophysics 134, 193-217.

Faber, S., Bamford, D., 1979. Lithospheric structural contrasts across the Caledonides of Northern Britain. Tectonophysics 56, 17-30.

Fan, W.M., Zhang, H.F., Baker, J., et al., 2000. On and off the North China Craton: where is the Archaean keel? Journal of Petrology 41, 933-950.

Ferré, E.C., Bordaries, C., Marsh, J.S., 2002. Magma flow inferred from AMS fabrics in a layered mafic sill, Insizwa, South Africa. Tectonophysics 354, 1-23.

Fillerup, M.A., Knapp, J.H., Knapp, C.C., et al., 2010. Mantle earthquakes in the absence of subduction? Continental delamination in the Romanian Carpathians. Lithosphere 2, 333-340.

Fischer, K.M., 2002. Flow and fabric deep down. Nature 415, 745-749.

Foster, A., Nimmo, F., 1996. Comparisons betweeen the rift systems of East Africa, Earth and Beta Regio, Venus. Earth and Planetary Science Letters 143, 183-195.

Fountain, D.M., Boundy, T.M., Austrheim, H., Rey, P., 1994. Eclogite-facies shear zonesdeep-crustal reflectors. Tectonophysics 232, 411-424

Franke, W., 1992. Phanerozoic structures and events in Central Europe. In: Blundell, D. (Ed.), A Continent Revealed: The European Geotraverse, vol. 1. Cambridge University Press, Reading, MA, pp. 164-180.

Franke, W., 1994. Exhumierung von Eklogiten im Saxothuringikum. Orogene Prozesse (Terra Nostra) 3/94, 38.

Franke, W., 2006. The Variscan orogen in Central Europe: construction and collapse. Geological Society of London, Memoirs 32, 333-343.

Franke, W., Doublier, M.P., Klama, K., Potel, S., Wemmer, K., 2011. Hot metamorphic core complex in a cold foreland. International Journal of Earth Sciences (Geologische Rundschau) 100, 753-785

Frankel, C., 1996. Volcanoes of the Solar System. Cambridge University Press, Cambridge, New York.

Fuchs, K., Wedepohl, K.H., 1983. Relation of geophysical and petrological models of upper mantle structure of the Rhenish massif. In: fuchs, K., von Gehlen, K., Mälzer, H., Murawski, H., Semmel, a. (Eds.), Plateau uplift-the Rhenish Shield-A Case History. Springer, Berlin-Heidelberg, pp. 352-363.

Gans, P.B., 1987. An open-system, 2-layer crustal stretching model for the eastern Great Basin. Tectonics 6, 1-12.

Gao, S., Rudnick, R.L., Yuan, H.-L., Liu, X.-M., Liu, Y.-S., Xu, W.-L., Ling, W.-L., Ayers, J., Wang, X.-C., Wang, Q.-H., 2004. Recycling lower continental crust in the North China craton. Nature 432, 892-897.

Gashawbeza, E.M., Klemperer, S.L., Wilson, C.K., et al., 2008. Nature of the crust beneath northwest Basin and Range province from teleseismic receiver function data. Journal of Geophysical Research 113, B10 Article Number: B10308.

Gebrande, H., Castellarin, A., Lüschen, E., Millahn, K., Neubauer, F., Nicolich, R. (Eds.), 2006. TRANSALP - a transect through a young collisional orogen. Tectonophysics Special Issue, 414. 282 pp. 
Gerya, T.V., Burg, J.P., 2007. Intrusion of ultramafic magmatic bodies into the continental crust: numerical simulation. Physics of the Earth and Planetary Interiors 160 , 124-142.

Given, I., Helmberger, D., 1981. Upper mantle structure of northwestern Eurasia. Journal of Geophysical Research 85, 7183-7194.

Gögüs, H.O., Pysklywec, R.N., 2008. Near-surface diagnostic of dripping or delaminating lithosphere. Journal of Geophysical Research 113, B11404. doi:10.1029/2007JB005123.

Green, D.H., Ringwood, A.E., 1967. An experimental investigation of the gabbro to eclogite transformation and its petrological applications. Geochimica et Cosmochimica Acta 31, 767-833.

Greenhagen, B.T., Lucey, P.G., Wyatt, M.B., et al., 2010. Global silicate mineralogy of the moon from the diviner lunar radiometer. Science 329, 1507-1509.

Griffin, W.L., Zhang, A., O'Reilly, S.Y., Ryan, C.G., 1998. Phanerozoic evolution of the lithosphere beneath the Sino-Korean craton. In: Flower, M.F.J., Chung, S.L., Lo, C.H., Lee, T.Y. (Eds.), Mantle dynamics and plate interactions in East Asia: AGU Geodynam. Ser., 27, pp. 107-126.

Grove, T.L., Parman, S.W., 2004. Thermal evolution of the Earth as recorded by komatiites. Earth and Planetary Science Letters 219, 173-187.

Gudkova, T.V., Zharkov, V.N., 2004. Mars: interior structure and excitation of free oscillations. Physics of the Earth and Planetary Interiors 142, 1-22.

Guo, Z., Wilson, M., Liu, J., 2007. Post-collisional adakites in south Tibet: products of partial melting of subduction-modified lower crust. Lithos 96, 205-224.

Handy, M.R., Brun, J.P., 2004. Seismicity, structure and strength of the lithosphere. Earth and Planetary Science Letters 223, 427-441.

Harig, C., Molnar, P., Houseman, G.A., 2008. Rayleigh-Taylor instability under a shear stress free top boundary condition and its relevance to removal of mantle lithosphere from beneath the Sierra Nevada. Tectonics 27, TC6019. doi:10.1029/2007TC002241.

Harper, C.L., Nyquist, L.E., Bansal, B., Wiesmann, H., Shih, C.-Y., 1995. Rapid accretion and early differentiation of Mars indicated by ${ }^{142 \mathrm{Nd}} /{ }^{144} \mathrm{Nd}$ in SNC meteorites. Science 267, 213-217.

Harrison, T.M., Blichert-Toft, J., Muller, W., Albarede, F., Holden, P., Mojzsis, S.J., 2005. Heterogeneous Hadean hafnium: evidence of continental crust at 4.4 to $4.5 \mathrm{Ga}$. Science 310, 1947-1950.

Hart, S.R., Zindler, A., 1986. In search of a bulk-Earth composition. Chemical Geology 57, 247-267.

Hatcher, R.D., Carlson, M.P., McBride, J.H., et al. (Eds.), 4-D framework of continental crust. Geological Society of America Memoirs 200, 653 pp.

Hawkesworth, C.J., Kemp, A.I.S., 2006a. Evolution of the continental crust. Nature 443 811-817.

Hawkesworth, C.J., Kemp, A.I.S., 2006b. The differentiation and rates of generation of the continental crust. Chemical Geology 226, 134-143.

Hawman, R.B., 2008. Crustal thickness variations across the Blue Ridge mountains, southern Appalachians: An alternative procedure for migrating wide-angle reflection data. Bulletin of the Seismological Society of America 98, 469-475. doi:10.1785/0120070027.

He, Y., Li, S., Hoefs, J., et al., 2011. Post-collisional granitoids from the Dabie orogen: new evidence for partial melting of a thickened continental crust. Geochimica et Cosmochimica Acta 75, 3815-3838.

Heermans, M., Faleide, J.I., Larsen, B.T., 2004. Late Carboniferous-Permian of NW Europe: an introduction to a new regional map. In: Wilson, M., Neumann, E.-R., Davies, G.R., Timmerman, M.J., Heeremans, M., Larsen, B.T. (Eds.), Permo-Carboniferous Magmatism and Rifting in Europe: Geological Society, London, Special Publications, 223, pp. 75-88.

Herrick, R., 1994. Resurfacing history of Venus. Geology 22, 703-706.

Hoernle, K., Abt, D.L., Fischer, K.M., et al., 2008. Arc-parallel flow in the mantle wedge beneath Costa Rica and Nicaragua. Nature 451, 1094-1097.

Hoffman, P.F., 1989. Speculations on Laurentia's first gigayear (2.0 to $1.0 \mathrm{Ga}$ ). Geology $17,135-138$.

Hofmann, A.W., Jochum, K.P., Seufert, M., White, W.M., 1986. Nb and Pb in oceanic basalts: new constraints on mantle evolution. Earth and Planetary Science Letters 79 33-45.

Holbrook, W.S., 1990. The crustal structure of the northwestern Basin and Range Province, Nevada, from wide-angle seismic data. Journal of Geophysical Research 95, 21 843-21 869.

Holliger, K., Levander, A., 1994. Lower crustal reflectivity modeled by rheological controls on mafic intrusions. Geology 22 (4), 367-370.

Houseman, G.A., Molnar, P., 1997. Gravitational (Rayleigh-Taylor) instability of a layer with non-linear viscosity and convective thinning of continental lithosphere. Geophysical Journal International 128, 125-150.

Huang, Z., Su, W., Peng, Y., Zheng, Y., Li, H., 2003. Rayleigh wave tomography of China and adjacent regions. Journal of Geophysical Research 108 (B2), 2073.

Hughes, S., Luetgert, J.H., 1991. Crustal structure of the western New-England Appalachians and the Adirondack Mountains. Journal of Geophysical Research 96, 16471-16494.

Huppert, H.E., Sparks, R.S.J., 1988. The generation of granitic magmas by intrusion of basalt into continental crust. Journal of Petrology 29, 599-624.

Iizuka, T., Nakai, S., Sahoo, Y.V., et al., 2010. The tungsten isotopic composition of Eoarchean rocks: implications for early silicate differentiation and core-mantle interaction on Earth. Earth and Planetary Science Letters 291, 189-200.

Iliha, DSS Group, 1993. A deep seismic sounding investigation of lithospheric heterogeneity and anisotropy beneath the Iberian Peninsula. Tectonophysics 221, 35-51.

Ito, K., Kennedy, G.C., 1971. An experimental study of the basalt-garnet granuliteeclogite transformation. AGU Geophysical Monograph 14, 303-314.

Jackson, M.J., Carlson, R.W., Kurz, M.D., Kempton, P.D., Francis, D., Blusztajn, J., 2010. Evidence for the survival of the oldest terrestrial mantle reservoir. Nature 466 853-858.
Janák, M., Plašienka, D., Frey, M., Cosca, M., Schmidt, S.Th., Lupták, B., Méres, Š., 2001. Cretaceous evolution of a metamorphic core complex, the Veporic unit, Western Carpathians (Slovakia): P-T conditions and in situ 40Ar/39Ar UV laser probe dating of metapelites. Journal of Metamorphic Geology 19, 197-216.

Japsen, P., Chalmers, J.A., 2000. Neogene uplift and tectonics around the North Atlantic: overview. Global and Planetary Change 24, 165-173.

Jeanloz, R., Mitchell, D.L., Sprague, A.L., de Pater, I., 1995. Evidence for a basalt-free surface on mercury and implications for internal heat. Science 268, 1455-1457.

Johnston, S.M., Hacker, B.R., Anderson, T.B., 2007. Exhuming Norwegian ultrahighpressure rocks: overprinting extensional structures and the role of the NordfjordSogn detachment zone. Tectonics 26, TC5001. doi:10.1029/2005TC001933.

Judenherc, S., Granet, M., Brun, J.-P., Poupinet, G., Plomerová, J., Mocquet, A., Achauer, U., 2002. Images of lithospheric heterogeneities in the Armorican segment of the Hercynian Range in France. Tectonophysics 358, 121-134.

Juhlin, C. Friberg, M., Echtler, H., Hismatulin, T., Rybalka, A., Green, A., Ansorge, J., 1998 Crustal structure of the middle Urals: results from the ESRU experiments. Tectonics $17,710-725$

Juhojuntti, N., Juhlin, C., Dyrelius, D., 2001. Crustal reflectivity underneath the Central Scandinavian Caledonides. Tectonophysics 334, 191-210.

Kaban, M.K., Schwintzer, P., Artemieva, I.M., Mooney, W.D., 2003. Density of continental roots: compositional and thermal effects. Earth and Planetary Science Letters 209, 53-69.

Kaneko, Y., Maruyama, S., Terabayashi, M., et al., 2000. Geology of the Kokchetav UHPHP metamorphic belt, Northern Kazakhstan. Island Arc 9, 264-283.

Kay, R.W., Kay, S.M., 1991. Creation and destruction of lower continental crust. Geologische Rundschau 80, 259-278.

Kay, R.W., Kay, M.S., 1993. Delamination and delamination magmatism. Tectonophysics 218, 177-189.

Kay, R.W., Kay, M.S., Arculus, R.J., 1992. Magma genesis and crustal processing. In: Fountain, D.M., Arculus, R., Kay, R.W. (Eds.), Continental lower crust. Dev. in Geotecton., 23. Elsevier, pp. 423-447.

Kelly, A., England, R.W., Maguire, P.K.H., 2007. A crustal seismic velocity model for the UK, Ireland and surrounding seas. Geophysical Journal International 171, 1172-1184.

Kemp, A.I.S., Hawkesworth, C.J., 2003. Granitic perspectives on the generation and secular evolution of the continental crust. In: Rudnick, R.L. (Ed.), Treatise on Geochemistry. The Crust, vol. 3. Elsevier-Pergamon, Oxford, pp. 349-410.

Kind, R., Yuan, X., Saul, J., et al., 2002. Seismic images of crust and upper mantle beneath Tibet: evidence for Eurasian plate subduction. Science 298, 1219-1221.

King, S.D., Anderson, D.L., 1995. An alternative mechanism of flood basalt formation. Earth and Planetary Science Letters 136, 269-279.

Kleine, T., Münker, C., Mezger, K., Palme, H., 2002. Rapid accretion and early core formation on asteroids and the terrestrial planets from Hf-W chronometry. Nature 418, 952-955.

Kleine, T., Palme, H., Mezger, K., Halliday, A.N., 2005. Hf-W chronometry of Lunar metals and the age and early differentiation of the Moon. Science 310 (5754), $1671-1674$

Klemperer, S., Hobbs, R., 1991. The BIRPS Atlas: Deep Seismic Reflection Profiles around the British Isles. Cambridge University Press, Cambridge, UK.

Knapp, J.H., Steer, D.N., Brown, L.D., Berzin, R., Suleimanov, A., Stiller, M., Luschen, E., Brown, D.L., Bulgakov, N., Kashubin, S.N., Rybalka, A.V., 1996. Lithosphere-scale seismic image of the Southern Urals from explosion-source reflection profiling. Science $274,226-228$.

Korenaga, J., Jordan, T., 2002. On the state of sublithospheric upper mantle beneath a supercontinent. Geophysical Journal International 149, 179-189.

Korenaga, J., Kelemen, P.B., 1997. Origin of gabbro sills in the Moho transition zone of the Oman ophiolite: implication for magma transport in the oceanic lower crust Journal of Geophysical Research 102, 27729-27749.

Korja, A., Heikkinen, P., 2005. The accretionary Svecofennian orogen-insight from the BABEL profiles. Precambrian Research 136, 241-268.

Korja, A., Hyönen, T., Tira, T., Heikkinen, P., 2009. Examining three-dimensional crusta heterogeneity in Finland. EOS. Transactions of the American Geophysical Union 90 (15), 129-130.

Kostyuchenko, S.L., Egorkin, A.V., Solodilov, L.N., 1999. Structure and genetic mechanisms of the Precambrian rifts of the East-European Platform in Russia by integrated study of seismic, gravity, and magnetic data. Tectonophysics 313, 9-28.

Koulakov, I., Zaharia, B., Enescu, B., et al., 2010. Delamination or slab detachment beneath Vrancea? New arguments from local earthquake tomography. Geochemistry, Geophysics, Geosystems 11 Article Number: Q03002.

Kukkonen, I.T., Lahtinen, R. (Eds.), 2006. Finish reflection experiment FIRE 2001-2005: Geol. Survey of Finland, Sp. Paper, 43. Espoo, 247 pp.

Kukkonen, I.T., Golovanova, I.V., Khachay, Yu.V., Druzhinin, V.S., Kasarev, A.M., Schapov, V.A., 1997. Low geothermal heat flow of the Urals fold belt-implications of low heat production, fluid circulation or paleoclimate? Tectonophysics 276, 63-85.

Kumar, P., Kind, R., Priestley, K., Dahl-Jensen, T., 2007. Crustal structure of Iceland and Greenland from receiver function studies. Journal of Geophysical Research 112 B03301. doi:10.1029/2005JB003991.

Kustowski, B., Ekstrom, G., Dziewonski, A.M., 2008. The shear-wave velocity structure in the upper mantle beneath Eurasia. Geophysical Journal International 174, 978-992.

Le Bas, M.J., 1987. Ultra-alkaline magmatism with or without rifting. Tectonophysics $143,75-84$.

Le Pichon, X., Henry, P., Goffe, B., 1997. Uplift of Tibet: From eclogites to granulitesimplications for the Andean Plateau and the Variscan belt. Tectonophysics 273 , 57-76.

Lee, D.-C., Halliday, A.N., 1995. Hafnium-tungsten chronometry and the timing of terrestrial core formation. Nature $378,771-774$ 
Lenardic, A., Moresi, L.N., 1999. Some thoughts on the stability of cratonic lithosphere: effects of buoyancy and viscosity. Journal of Geophysical Research 104, 12747-12759.

Lenardic, A., Nimmo, F., Moresi, L., 2004. Growth of the hemispheric dichotomy and the cessation of plate tectonics on Mars. Journal of Geophysical Research 109. doi:10.1029/2003JE002172.

Lerch, D.W., Glen, J.M.G., Ponce, D.A., et al., 2007. Crustal structure of the northwestern Basin and Range Province and its transition to unextended volcanic plateaus. Geochemistry, Geophysics, Geosystems 8 Article Number: Q02011.

Levander, A., Schmandt, B., Miller, M.S., Liu, K., Karlstrom, K.E., Crow, R.S., Lee, C.-T.A., Humphreys, E.D., 2011. Continuing Colorado plateau uplift by delamination-style convective lithospheric downwelling. Nature 472, 461-465.

Lévy, F., Jaupart, C., Mareschal, J.-C., Bienfait, G., Limare, A., 2010. Low heat flux and large variations of lithospheric thickness in the Canadian Shield. Journal of Geophysical Research 115, B06404. doi:10.1029/2009JB006470.

Lewis, J.S., 1988. Origin and composition of Mercury. In: Vilas, F., et al. (Ed.), Mercury. Univ. Ariz. Press, Tuscon, Az, pp. 651-666.

Lippitsch, R., Kissling, E., Ansorge, J., 2003. Upper mantle structure beneath the Alpine orogen from high-resolution teleseismic tomography. Journal of Geophysical Research 108 (B8), 2376. doi:10.1029/ 2002JB002016.

Lissauer, J.J., 1997. It's not easy to make the Moon. Nature 389, 327-328.

Lliboutry, L., 1999. Quantitative Geophysics and Geology. Springer-Praxis Books, Springer, Heidelberg. $480 \mathrm{pp}$.

Lorinczi, P., Houseman, G.A., 2009. Lithospheric gravitational instability beneath the Southeast Carpathians. Tectonophysics 474, 322-336.

Lucey, P., Korotev, R.L., Gillis, J.J., et al., 2006. Understanding the lunar surface and space-Moon interactions. Reviews in Mineralogy and Geochemistry 60, 83-219.

Lustrino, M., Wilson, M., 2007. The circum-Mediterranean anorogenic Cenozoic igneous province. Earth Science Reviews 81, 1-65.

Lyngsie, S.B., Thybo, H., Lang, R., 2007. Rifting and lower crustal reflectivity: a case study of the intracratonic Dnieper-Donets rift zone, Ukraine. Journal of Geophysical Research 112, B12402. doi:10.1029/2006JB004795.

Mackwell, S.J., Zimmerman, M.E., Kohlstedt, D.L., 1998. High-temperature deformation of dry diabase with application to tectonics on Venus. Journal of Geophysical Research 103, 975-984.

Large Igneous Provinces: Continental, Oceanic, and Planetary Flood Volcanism. In: Mahoney, J.J., Coffin, M.F. (Eds.), American Geophysical Union, Geophysical Monograph Series, $100.438 \mathrm{pp}$.

Mann, P., Taira, A., 2004. Global tectonic significance of the Solomon Islands and the Ontong Java Plateau convergent zone. Tectonophysics 389, 137-190.

Marotta, A.M., Bayer, U., Scheck-Wenderoth, M., Thybo, H., 2001. The stress filed below the NE German Basin: effects induced by the Alpine collision. Geophysical Journal International 144, F8-F12.

Martin, M., Wenzel, F., the CALIXTO working group, 2006. Geophysical and petrological modelling of the structure and composition of the crust and upper mantle in complex geodynamic settings: the Tyrrhenian Sea and surroundings. Earth Science Reviews $80.265,1-46$

Martinez Catalan, J.R., 1990. A non-cylindrical model for the northwest Iberian allochthonous terranes and their equivalents in the Hercynian belt of Western Europe. Tectonophysics 179, 253-272.

Matte, P., 1986. Tectonics and plate tectonics model for the Variscan Belt of Europe. Tectonophysics 126, 329-374.

Matte, P., 1991. Accretionary history and crustal evolution of the Variscan belt in Western Europe. Tectonophysics 196, 309-337.

Maystrenko, Y., Stovba, S., Stephenson, R., Bayer, U., Menyoli, E., Gajewski, D., Huebscher, C., Rabbel, W., Saintot, A., Starostenko, V., Thybo, H., Tolkunov, A., 2003. Crustal-scale pop-up structure in cratonic lithosphere: DOBRE deep seismic reflection study of the Donbas fold belt, Ukraine. Geology 31, U732-U733.

McBride, J.M., White, R.S., Smallwood, J.R., England, R.W., 2004. Must magmatic intrusion in the lower crust produce reflectivity? Tectonophysics 388, 271-297.

McCarthy, J., Thompson, G.A., 1988. Seismic imaging of extended crust with emphasis on the western United States. Geological Society of America Bulletin 100, 1361-1374.

McCulloch, M.T., Bennett, V.C., 1994. Progressive growth of the Earth's continental crust and depleted mantle: geochemical constraints. Geochimica et Cosmochimica Acta 58 (21), 4717-4738.

McCulloch, M.T., Bennett, V.C. 1998. Early differentiation of the Earth: an isotopic perspective. In: Jackson, I. (Ed.), The Earth's Mantle: Composition, Structure, and Evolution. Cambridge Univ. Press, pp. 127-158.

McDonough, W.F., Sun, S.S., 1995. The composition of the Earth. Chemical Geology 120, 223-253.

McGlashan, N., Brown, L., Kay, S., 2008. Crustal thickness in the central Andes from teleseismically recorded depth phase precursors. Geophysical Journal International $175,1013-1022$.

McGreggor, I.D., Manton, W.I., 1986. Roberts Victor Eclogites: ancient oceanic crust. Journal of Geophysical Research 91, 14063-14079.

McKenzie, D., 1984. A possible mechanism for epeirogenic uplift. Nature 307, 616-618.

McKenzie, D., Bickle, M.J., 1988. The volume of and composition of melt generated by extension of the lithosphere. Journal of Petrology 29, 625-679.

McKenzie, D., Nimmo, F., Jackson, J.A., Gans, P.B., Miller, E.L., 2000. Characteristics and consequences of flow in the lower crust. Journal of Geophysical Research 105, 11029-11046.

McKenzie, D., Jackson, J., Priestley, K., 2005. Thermal structure of oceanic and continental lithosphere. Earth and Planetary Science Letters 233, 337-349.

McKerrow, W.S., Dewey, J.F., Scotese, C.R., 1991. The Ordovician and Silurian development of the Iapetus Ocean. Spec. Papers in Palaeontology, No. 44, pp. 165-178.
McLennan, S.M., Taylor, S.R., 1982. Geochemical constraints on the growth of the continental crust. Journal of Geology 90, 347-361.

McNamara, A.K., Niocaill, C.M., van der Pluijm, B.A., Van der Voo, R., 2001. West African proximity of the Avalon terrane in the latest Precambrian. GSA Bulletin 113, $1161-1170$

Meissner, R., 1986. The continental crust. : Int. Geophys. Series, vol. 34. Academic Press, INC, Orlando. $425 \mathrm{pp}$

Meissner, R., Bortfeld, R.K., 1990. DEKORP Atlas. Springer Verlag, Berlin, Heidelberg. 80 pp.

Meissner, R., Kern, H., 2008. Earthquakes and strength in the laminated lower crustcan they be explained by the "Corset model" ? Tectonophysics 448, 49-59.

Meissner, R., Rabbel, W., 1999. Nature of crustal reflectivity along the DEKORP profiles in Germany in comparison with reflection patterns from different tectonic units worldwide: A review. Pure and Applied Geophysics 156, 7-28.

Meissner, R., Strehlau, J., 1982. Limits of stresses in continental crusts and their relation to the depth-frequency distribution of shallow earthquakes. Tectonics 1, 73-89.

Meissner, R., Wever, Th., Durbaum, H.J., 1986. The Variscan crust from a geophysical point of view: reflection seismics. In: Freeman, R., Mueller, St., Giese, P. (Eds.) Proc. 3rd EGT Workshop: The Central Segment. ESF, Strasbourg, pp. 93-98.

Meissner, R., Brown, L., Durbaum, H.-J., Franke, W., Fuchs, K., Seifert, F. (Eds.), 1991. Continental lithosphere: deep seismic reflections: AGU, Geodynam. Ser., 22. 450 pp.

Meissner, R., Rabbel, W., Kern, H., 2006. Seismic lamination and anisotropy of the lower continental crust. Tectonophysics 416, 81-99.

Menard, G., Molnar, P., 1988. Collapse of a Hercynian Tibetan plateau into a late Paleozoic European Basin and range province. Nature 334, 235-237.

Mengel, K., Kern, H., 1992. Evolution of the petrological and seismic Moho implications for the continental crust-mantle boundary. Terra Nova 4, 109-116.

Mengel, K., Sachs, P.M., Stosch, H.G., Woeruer, G., Look, G., 1991. Crustal xenoliths from Cenozoic volcanic fields of West Germany: implications for structure and composition of the continental crust. Tectonophysics 195, 271-289.

Michaut, C., Jaupart, C., 2004. Nonequilibrium temperatures and cooling rates in thick continental lithosphere. Geophysical Research Letters 31, L24602.

Mo, X.X., Hou, Z.Q., Niu, Y.L., et al., 2007. Mantle contributions to crustal thickening during continental collision: evidence from Cenozoic igneous rocks in southern Tibet. Lithos 96, 225-242.

Molnar, P.H., Tapponier, P., 1975. Cenozoic tectonics of Asia: effects of continental collision. Science 189, 144-154.

MONA LISA Working Group, 1997. MONA LISA: Deep seismic investigations of the lithosphere in the southeastern North Sea. Tectonophysics 269, 1-19.

Mooney, W.D., Meissner, R., 1992. Multigenetic origin of crustal reflectivity: a review of seismic reflection profiling. In: Fountain, D.M., Arculus, R., Kay, R.W. (Eds.), Continental lower crust. Dev. in Geotecton., 23. Elsevier, pp. 201-268.

Moresi, L., Solomatov, V., 1998. Mantle convection with a brittle lithosphere: thoughts on the global tectonic styles of the Earth and Venus. Geophysical Journal International 133, 669-682.

Morozov, A.F. (Ed.), 2001. Deep structure and geodynamics of the southern Urals (the URALSEIS project). Ministry of Natural Resources of Russia, Tver. $286 \mathrm{pp}$

Murphy, M.A., Yin, A., Harrison, T.M., Durr, S.B., Chen, Z., Ryerson, F.J., Kidd, W.S.F. Wang, X., Zhou, X., 1997. Significant crustal shorting in south-central Tibet prior to the Indo-Asian collision. Geology 25, 719-722.

Nelson, K.D., 1992. Are crustal thickness variations in old mountain belts like the Appalachians a consequence of lithospheric delamination? Geology 20, 498-502.

Neumann, G.A., Zuber, M.T., Wieczorek, M.A., et al., 2004. Crustal structure of Mars from gravity and topography. Journal of Geophysical Research 109 (E8) doi:10.1029/2004JE002262 Article Number: E08002.

Nikulin, A., Levin, V., Park, J., 2009. Receiver function study of the Cascadia megathrust: evidence for localized serpentinization. Geochemistry, Geophysics, Geosystems 10 Article Number: Q07004.

Nilsson, M.K.M., Soderlund, U., Ernst, R.E., et al., 2010. Precise U-Pb baddeleyite ages of mafic dykes and intrusions in southern West Greenland and implications for a possible reconstruction with the Superior craton. Precambrian Research 183, 399-415.

Nimmo, F., McKenzie, D., 1998. Volcanism and tectonics on Venus. Annual Review of Earth and Planetary Sciences 26, 23-51.

Nimmo, F. Stevenson, D.J., 2000. Influence of early plate tectonics on the thermal evolution and magnetic field of Mars. Journal of Geophysical Research 105, 11969-11980. Nisbet, E.G., Fowler, C.M.R., 1983. Model for Archean plate tectonics. Geology 11, 376-379.

Nolet, G., Zielhuis, A., 1994. Low S velocities under the Tornquist-Teisseyre zone: evidence from water injection into the transition zone by subduction. Journal of Geophysical Research 99, 15813-15820.

O'Neill, H.S.C., Palme, H., 1998. Composition of the Silicate Earth: implications for accretion and core formation. In: Jackson, I. (Ed.), The Earth's Mantle: Composition, Structure, and Evolution. Cambridge Univ. Press, pp. 3-125.

Olsson, J.R., Soderlund, U, Klausen, M.B, Ernst, RE, 2010. U-Pb baddeleyite ages linking major Archean dyke swarms to volcanic-rift forming events in the Kaapvaal craton (South Africa), and a precise age for the Bushveld Complex. Precambrian Research 183, 490-500.

Oncken, O., 1994. The rise and fall of an orogen-fundamental aspects of the European Variscides and constraints. Terra Nostra: Orogene Prozesse. DFG-Schwerpunkt, p. 128.

Oncken, O., 1998. Orogenic mass transfer and reflection seismic patterns-evidence from DEKORP sections across the European Variscides (central Germany). Tectonophysics 286, 47-61.

O'Neill, C., Jellinek, A.M., Lenardic, A., 2007a. Conditions for the onset of plate tectonics on terrestrial planets and moons. Earth and Planetary Science Letters 261 20-32.

O'Neill, C., Lenardic, A., Moresi, L., Torsvik, T.H., Lee, C.-T.A., 2007b. Episodic Precambrian subduction. Earth and Planetary Science Letters 262, 552-562. 
Ottemoeller, L., Michs, V., 2004. The crustal structure of Norway from inversion of teleseismic receiver studies. Journal of Seismology 7 (1), 35-48.

Pavlenkova, N.I., 1996. Crust and upper mantle structure in northern Eurasia from seismic data. Advances in Geophysics 37, 1-133.

Peacock, S.M., 2001. Are the lower planes of double seismic zones caused by serpentine dehydration in subducting oceanic mantle? Geology 29, 299-302.

Petford, N., Cruden, A.R., McCaffrey, K.J.W., et al., 2000. Granite magma formation, transport and emplacement in the Earth's crust. Nature 408,669-673.

Pfiffner, O.A., 1990. Crustal shortening of the Alps along the EGT profile. In: Freemann, R., et al. (Ed.), The European Geotraverse: Integrative Studies. ESF, Strasbourg, pp. 255-262.

Pfiffner, O.A., Schlunegger, F., Buiter, S.J.H., 2001. The Swiss Alps and their periphera foreland basin: stratigraphic response to deep crustal processes. Tectonics 21 doi:10.1029/2002TC001465 Article Number: 1054.

Piromallo, C., Morelli, A., 2003. P-wave tomography of the mantle under the AlpineMediterranean area. Journal of Geophysical Research 108 (B2) art. no. 2065.

Plenefisch, T., Klinge, K., Kind, R., 2000. Upper mantle anisotropy at the transition zone of the Saxothuringicum and Moldanubicum in southeast Germany revealed by shear wave splitting. Geophysical Journal International 144, 309-319.

Plomerova, J., Babushka, V., Sileny, J., Horalek, J., 1998. Seismic anisotropy and velocity variations in the mantle beneath the Saxothuringicum-Moldanubicum contact in central Europe. Pure and Applied Geophysics 151, 365-394.

Pollack, H.K.N., 1986. Cratonization and the thermal evolution of the mantle. Earth and Planetary Science Letters 80, 175-182.

Pollack, H.N., Chapman, D.S., 1977. On the regional variation of heat flow, geotherms and lithospheric thickness. Tectonophysics 38, 279-296.

Poppeliers, C., 2007. Estimating vertical stochastic scale parameters from seismic reflection data: deconvolution with non-white reflectivity. Geophysical Journal International 168, 769-778.

Praus, O., Pecová, J., Petr, V., Babuška, V., Plomerová, J., 1990. Magnetotelluric and seismological determination of lithosphere-asthenosphere transition in Central Europe. Physics of the Earth and Planetary Interiors 60, 212-228.

Pritchard, M.E., Stevenson, D.J., 2000. Thermal aspects of a lunar origin by giant impact. In: Canup, R., Righter, K. (Eds.), Origin of the Earth and Moon. Univ. of Arizona Press, Tucson, pp. 179-196.

Prussen, E., 1991. The reflection Moho along the COCORP Northwest US-Transect: continental lithosphere: deep seismic reflections. AGU Geodynamics Series 22, 315-322.

Rabbel, W., Forste, K., Schulze, A., et al., 1995. A high-velocity layer in the lower crust of the North German Basin. Terra Nova 7, 327-337.

Reymer, A.P.S., Schubert, G., 1984. Phanerozoic addition rates to the continental crust. Tectonics 3, 63-77.

Ringwood, A.E., Green, D.H., 1966. An experimental investigation of the gabbroeclogite transformation and some geophysical implications. Tectonophysics 3, 383-427.

Ritter, J.R.R., Christensen, U.R. (Eds.), 2007. Mantle Plumes-A multidisciplinary Approach. Springer Verlag, Heidelberg. 502 pp.

Roberts, A.W., White, R.S., Christie, P.A.F., 2009. Imaging igneous rocks on the North At lantic rifted continental margin. Geophysical Journal International 179, 1024-1038.

Robinson, M.S., Murchie, S.L., Blewett, D.T., Domingue, D.L., Hawkins, S.E., Head, J.W Holsclaw, G.M., McClintock, W.E., McCoy, T.J., McNutt, R.L., Prockter, L.M., Solomon, S.C., Watters, T.R., 2008. Reflectance and color variations on Mercury: regolith processes and compositional heterogeneity. Science 321, 66-69.

Rollinson, H., 1997. Eclogite xenoliths in west African kimberlites as residues from $\mathrm{Ar}-$ chaean granitoid crust formation. Nature 389, 173-177.

Ross, A.R., Brown, L.D., Pannonont, P., Nelson, K.D., Haines, S., Wenjin, C., Jingru, G., 2004. Deep reflection surveying in Central Tibet: lower crustal layering and crustal flow. Geophysical Journal International 156, 115-128.

Rothery, D., Marinangeli, L., Anand, M., et al., 2010. Mercury's surface and composition to be studied by BepiColombo. Planetary and Space Science 58, 21-39.

Rubie, D.C., 1990. Role of kinetics in the formation and preservation of eclogites. In: Carswell, D.A. (Ed.), Eclogite Facies Rocks. Blackie, Glasgow, pp. 111-140.

Rudnick, R.L., 1995. Making continental crust. Nature 378, 571-578.

Rudnick, R.L. (Ed.), 2003. The Crust Treatise on Geochemistry, vol. 3. Elsevier-Pergamon, Oxford.

Ryder, G., 2003. Bombardment of the Hadean Earth: wholesome or deleterious? Astrobiology 3, 3-6.

Salters, V.J.M., Stracke, A., 2004. Composition of the depleted mantle. Geochemistry, Geophysics, Geosystems 5. doi:10.1029/2003GC000597 Article Number: 005004

Sandrin, A., Thybo, H., 2008. Deep seismic investigation of crustal extensional structures in the Danish Basin. Geophysical Journal International 173, 623-641.

Schmid, S.M., Pfiffner, O.A., Froitzheim, N., Schoenborn, G., Kissling, E., 1996. Geophysicalgeological transect and tectonic evolution of the Swiss-Italian Alps. Tectonics 15 1036-1064.

Scholl, D.W., von Huene, R., 2007. Crustal recycling at modern subduction zones applied to the past-issues of growth and preservation of continental basemen crust, mantle geochemistry, and supercontinent reconstruction. In: Hatcher, R.D Carlson, M.P., McBride, J.H., et al. (Eds.), 4-D framework of continental crust: Geological Society of America Memoirs, 200, pp. 9-32.

Schott, B., Schmeling, H., 1998. Delamination and detachment of a lithospheric root Tectonophysics 296, 225-247.

Sengör, A.M.C., Natal'in, B.A., Burtman, V.S., 1993. Evolution of the Altaid tectonic collage and Palaeozoic crustal growth in Eurasia. Nature 364, 299-307.

Shapiro, N., Hager, B.H., Jordan, T.H., 1999. Stability and dynamics of the continental tectosphere. Lithos 48, 135-152.

Sharkov, E.V., Bogatikov, O.A., 2009. Do terrestrial planets evolve according to the same scenario? Geological and petrological evidence. Petrology 17, 629-652. doi:10.1134/ S0869591109070017.
Sibuet, J.C., Srivastava, S.P., Spakman, W., 2004. Pyrenean orogeny and plate kinematics. Journal of Geophysical Research 109 (B8) Article Number: B08104.

Simancas, J.F., Carbonell, R., Lodeiro, F.G., et al., 2003. Crustal structure of the transpressional Variscan orogen of SW Iberia: SW Iberia deep seismic reflection profile (IBERSEIS). Tectonics 22 Article Number: 1062.

Simons, M., Solomon, S.C., Hager, B.H., 1997. Localization of gravity and topography: constraints on the tectonics and mantle dynamics of Venus. Geophysical Journal International 131, 24-44.

Singh, S.C., Crawford, W.C., Carton, H., et al., 2006. Seismic reflection images of the Moho underlying melt sills at the East Pacific Rise. Nature 442, 287-290.

Sinigoi, S., Antonini, P., Demarchi, G., Longinelli, A., Mazzucchelli, M., 1991. Interaction of mantle and crustal magmas in the southern part of the Ivrea Zone (Italy). Contributions to Mineralogy and Petrology 108, 385-395.

Sizova, E., Gerya, T., Brown, M., Perchuk, L.L., 2010. Subduction styles in the Precambrian: insight from numerical experiments. Lithos 116, 209-229.

Sleep, N.H., 1994. Martian plate tectonics. Journal of Geophysical Research 99, 5639-5655.

Sleep, N.H., 2003. Survival of Archean cratonic lithosphere. Journal of Geophysical Research 108. doi:10.1029/2001JB000169.

Sohl, F., Schubert, G., 2007. Interior structure, composition, and mineralogy of the terrestrial planets. Treatise on Geophysics, 10. Elsevier, pp. 27-68.

Sohl, F., Schubert, G., Spohn, T., 2005. Geophysical constraints on the composition and structure of the Martian interior. Journal of Geophysical Research 110, E12008. doi:10.1029/2005JE002520.

Solomatov, V.S., Moresi, L., 1997. Three regimes of mantle convection with nonNewtonian viscosity and stagnant lid convection on the terrestrial planets. Geophysical Research Letters 24, 1907-1910.

Solomon, S.C., 1980. Differentiation of crusts and cores of the terrestrial planets: lessons for the early Earth? Precambrian Research 10, 177-194.

Solomon, S., 2003. Mercury: the enigmatic innermost planet. Earth and Planetary Science Letters 216, 441-455.

Solomon, S.C., Smrekar, S.E., Bindschadler, D., et al., 1992. Venus tectonics-an overview of Magellan observations. Journal of Geophysical Research, Planets 97 (E8), 13199-13255.

Solomon, S.C., Aharonson, O., Aurnou, J.M., et al., 2005. New perspectives on ancient Mars. Science 307, 1214-1220.

Souriau, A., Granet, M., 1995. A tomographic study of the lithosphere beneath the Pyrenees from local and teleseismic data. Journal of Geophysical Research 100, 18117-18134.

Souriau, A., Pauchet, H., 1998. A new synthesis of Pyrenean seismicity and its tectonic implication. Tectonophysics 290, 221-244.

Spear, F.S., 1993. Metamorphic Phase Equilirbia and Pressure-Temperature-Time Paths. Mineral. Soc. America. 799 pp.

Spohn, T., Sohl, F., Wieczerkowski, K., Conzelmann, V., 2001. The interior structure of Mercury: what we know, what we expect from BepiColombo. Planetary and Space Science 49, 1561-1570.

Sroda, P., Czuba, W., Grad, M., et al., 2006. Crustal and upper mantle structure of the Western Carpathians from CELEBRATION 2000 profiles CEL01 and CEL04: seismic models and geological implications. Geophysical Journal International 167, 737-760.

Steer, D.N., Knapp, J.H., Brown, L.D., Echtler, H.P., Brown, D.L., Berzin, R., 1998. Deep structure of the continental lithosphere in an unextended orogen (URSEIS 1995). Tectonics 17, 143-157.

Stratford, W.R., Stern, T.A., 2004. Strong seismic reflections from the mantle represent relict subduction zones with the continental lithosphere. Geology 24 (1), 39-42.

Stratford, W., Thybo, H., Faleide, J.-I., Olesen, O., Tryggvason, A., 2009. New Moho Map for onshore southern Norway. Geophysical Journal International 178, 1755-1765.

Sun, S., McDonough, W.F., 1989. Chemical and isotopic systematics of oceanic basalts: implications for mantle composition and processes. Special Publication-Geological Society of London 42, 313-345.

Surkov, Y.A., Moskalyeva, L.P., Kharyukova, V., et al., 1986. Venus rock composition at the Vega 2 landing site. Journal of Geophysical Research 91, E215-E218.

Tackley, P.J., 2000. Mantle convection and plate tectonics: toward an integrated physical and chemical theory. Science 288, 2002-2007.

Tanner, B., Meissner, R., 1996. Caledonian deformation upon southwest Baltica and its tectonic implications: alternatives and consequences. Tectonics 13 (4), 803-812.

Taylor, S.R., 1989a. Growth of planetary crusts. Tectonophysics 161, 147-156.

Taylor, S.R., 1989b. Geophysical framework of the Appalachians and adjacent Grenville Province. In: Pakiser, L.C., Mooney, W.D. (Eds.), Geophysical framework of the continental United States: GSA Mem., 172, pp. 317-348.

Taylor, S.R., McLennan, S.M., 1985. The Continental Crust: Its Composition and Evolution. Blackwell, Oxford. 312 pp.

Taylor, S.R., McLennan, S.M., 1995. The geochemical evolution of the continental crust. Reviews of Geophysics 33, 241-265.

Taylor, G.J., Scott, E.R.D., 2004. Mercury. In: Davis, A.M. (Ed.), Treatise on Geochemistry: Meteorites, Comets, and Planets, 1. Elsevier, Oxford and San Diego, pp. 477-485.

Tesauro, M., Kaban, M.K., Cloetingh, S.A.P.L., 2008. EuCRUST-07: a new reference model for the European crust. Geophysical Research Letters 35, L05313. doi:10.1029/ 2007GL32244.

Thybo, H., 1997. Geophysical characteristics of the Tornquist Fan area, northwest TESZ: indication of Late Carboniferous to Early Permian dextral transtension. Geological Magazine 134, 597-606.

Thybo, H., Nielsen, C.A., 2009. Magma-compensated crustal thinning in continental rift zones. Nature 457, 873-876.

Thybo, H., Perchuc, E., Gregersen, S., 1998. Interpretation in statu nascendi of seismic wide-angle reflections based on EUGENO-S data. Tectonophysics 289, 281-294.

Thybo, H., Pharaoh, T., Guterch, A. (Eds.), 2002. The Trans European Suture Zone II: Tectonophysics, $360.314 \mathrm{pp}$. 
Tondi, R., Achauer, U., Landes, M., et al., 2009. Unveiling seismic and density structure beneath the Vrancea seismogenic zone, Romania. Journal of Geophysical Research 114 Article Number: B11307.

Torsvik, T.H., Smethurst, M.A., Meert, J.G., Van der Voo, R., McKerrow, W.S., Brasier, M.D., Sturt, B.A., Walderhaug, H.J., 1996. Continental break-up and collision in the Neoproterozoic and Palaeozoic-a tale of Baltica and Laurentia. Earth Science Reviews 40, 229-258.

TRANSALP Working Group, 2002. First deep reflection images of the Eastern Alps reveal giant crustal wedges and transcurrent ramps. Geophysical Research Letters 29 (10). doi:10.1092/2002GRL014911.

Trofimov, V.A., 2006. Structural features of the earth's crust and petroleum potential: first results of CMP Deep Seismic Survey along the geotraverse across the VolgaUrals petroliferous province. Doklady Earth Sciences 411 (8), 1178-1183.

Tryggvason, A., Lund, C.-E., Friberg, M., 1998. A two-dimensional seismic velocity model across the transition zone between the Baltic Shield and the North German Basin-the EUGENO-S profile 1 revisited. Tectonophysics 290, 47-58.

Turcotte, D.L., 1993. An episodic hypothesis for Venusian tectonics. Journal of Geophysical Research 98, 17061-17068.

Turcotte, D.L., Shcherbakov, B.D., Malamud, B.D., Kucinskas, A.B., 2002. Is the Martian crust also the Martian elastic lithosphere? Journal of Geophysical Research 107. doi:10.1029/2001JE001594.

Turner, S., et al., 1996. Post-collision, shoshonitic volcanism on the Tibetan Plateau: implications for convective thinning of the lithosphere and the source of ocean island basalts. Journal of Petrology 37, 45-71.

Vacher, P., Souriau, A., 2001. A three-dimensional model of the Pyrenean deep structure based on gravity modelling, seismic images and petrological constraints. Geophysical Journal International 145, 460-470.

van der Hilst, R.D., Widiyantoro, S., Engdahl, E.R., 1997. Evidence for deep mantle circulation from global tomography. Nature 386, 578-584.

van der Lee, S., Nolet, G., 1997. Seismic image of the subducted trailing fragments of the Farallon plate. Nature 386, 266-269.

Van Kranendonk, M.J., Smithies, R.H., Hickman, A.H., et al., 2010. Evidence for Mesoarchean (similar to $3.2 \mathrm{Ga}$ ) rifting of the Pilbara Craton: the missing link in an early Precambrian Wilson cycle. Precambrian Research 177, 145-161.

Van Thienen, P., Vlaar, N.J., Van den Berg, A.P., 2004. Plate tectonics on the terrestrial planets. Physics of the Earth and Planetary Interiors 142, 61-74.

Veizer, J., Jansen, S.L., 1985. Basement and sedimentary recycling-2. Time dimension to global tectonics. Journal of Geology 93, 625-643.

Vejbaek, O.V., 1990. The Horn Graben, and its relationship to the Oslo Graben and the Danish Basin. Tectonophysics 178, 29-49.

Voshage, H., Hofmann, A.W., Mazzucchelli, M., Rivalenti, S., Raczek, I., Demarchi, G., 1990. Isotopic evidence from the Ivrea Zone for a hybrid lower crust formed by hybrid underplating. Nature 347, 731-736.

Warner, M., Morgan, J., Barton, P., Morgan, P., Price, C., Jones, K., 1996. Seismic reflections from the mantle present relict subduction zones within the continental lithosphere. Geology 24, 39-42.

Wedepohl, K.H., 1995. The composition of the continental crust. Geochimica et Cosmochimica Acta 59, 1217-1232.

Wenzel, F., Sandmeier, K.J., Walde, W., 1987. Properties of the lower crust from modeling refraction and reflection data. Journal of Geophysical Research 92, 11575-11583.

Wieczorek, M., Jolliff, B.L., Khan, A., et al., 2006. The constitution and structure of the lunar interior. Reviews in Mineralogy and Geochemistry 60, 221-364.
Willingshofer, F., Cloetingh, S., 2003. Present-day lithospheric strength of the eastern Alps and its relationship to neotectonics. Tectonics 22 (6), 14/1-14/15. doi:10.1029/2002. Wilson, M., 1995. Igneous petrogenesis. Chapman \& Hall, London, New York, Tokyo. 475 pp.

Wilson, M., Neumann, E.-R., Davies, G.R., Timmerman, M.J., Heeremans, M., Larsen, B.T. 2004. Permo-Carboniferous magmatism and rifting in Europe. Geological Society of London, Special Publications 223, 1-10.

Wittlinger, G., Vergne, J., Tapponnier, P., Farra, V., Poupinet, G., Jiang, M., Su, H., Herquel, G., Paul, A., 2004. Teleseismic imaging of subducting lithosphere and Moho offsets beneath western Tibet. Earth and Planetary Science Letters 221, 117-130.

Wortel, R., Spakman, W., 2000. Subduction and slab detachment in the MediterraneanCarpathian region. Science 290, 1910-1917.

Wu, J., Mereu, R.F., 1991. Seismic reflectivity patterns of the Kapuskasing structura zone. In: Meissner, R. (Ed.), Continental Lithosphere: Deep Seismic Reflections: AGU Geodyn. Ser., 22, pp. 47-52.

Xu, Y.G., Huang, X.L., Ma, J.L., et al., 2004. Crust-mantle interaction during the tectonothermal reactivation of the North China Craton: constraints from SHRIMP zircon $\mathrm{U}-\mathrm{Pb}$ chronology and geochemistry of Mesozoic plutons from western Shandong. Contributions to Mineralogy and Petrology 147, 750-767.

Yale, B.L., Carpenter, S.J., 1998. Large igneous provinces and giant dyke swarms: proxies for supercontinent cyclicity and mantle convection. Earth and Planetary Science Letters 163, 109-122.

Yang, W.C., 2003. Flat mantle reflectors in Eastern China: possible evidence of lithospheric thinning. Tectonophysics 369, 219-230.

Ye, K., Cong, B.L., Ye, D.I., 2000. The possible subduction of continental material to depths greater than $200 \mathrm{~km}$. Nature 407, 734-736.

Zagorevski, A., Rogers, N., van Staal, C.R., McNicoll, V., Lissenberg, C.J., Valverde-Vaquero, P., 2006. Lower to Middle Ordovician evolution of peri-Laurentian arc and backarc complexes in Iapetus: constraints from the Annieopsquotch accretionary tract, central Newfoundland. GSA Bulletin 118, 324-342.

Zandt, G., Gilbert, H., Owens, T.J., Ducea, M., Saleeby, J., Jones, C.H., 2004. Active foundering of a continental arc root beneath the southern Sierra Nevada in California. Nature 431, 41-46.

Zegers, T.E., van Keken, P.E., 2001. Middle Archean continent formation by crustal delamination. Geology 29, 1083-1086.

Zhao, W., Nelson, K.D., Project INDEPTH Team, 1993. Deep seismic reflection evidence for continental underthrusting beneath southern Tibet. Nature 366, 557-559.

Zhong, S., Gurnis, M., 1996. Interaction of weak faults and non-Newtonian rheology produces plate tectonics in a 3D model of mantle flow. Nature 383, 245-247.

Ziegler, P.A., 1992. European Cenozoic rift system. Tectonophysics 208, 91-111.

Ziegler, P., Cloetingh, S., 2004. Dynamic processes controlling evolution of rifted basins. Earth Science Reviews 64, 1-50.

Ziegler, P.A., Dèzes, P., 2006. Crustal evolution of Western and Central Europe. Geological Society of London, Memoirs 32, 43-56.

Zielhuis, A., Nolet, G., 1994. Deep seismic expression of an ancient plate boundary in Europe. Science 265, 79-81.

Zonenshain, L.P., Kuzmin, M.I., Natapov, L.M. (Eds.), 1990. Geology of the USSR; a platetectonic synthesis: American Geophysical Union, Geodynamics Series, 21.

Zuber, M.T., 2001. The crust and mantle of Mars. Nature 412, 220-227. 